



\section{Normbedragen extra herinzaai grasland door grondwaterwinning}

Auteurs

I.E. Hoving ${ }^{1}$, G. Holshof ${ }^{1}$, J.R. van der Schoot $^{2}$ en R.F.A. Hendriks ${ }^{3}$

${ }^{1}$ Wageningen Livestock Research

2 Wageningen Plant Research

${ }^{3}$ Wageningen Environmental Research

Dit onderzoek is uitgevoerd door Wageningen Livestock Research, in opdracht van en gefinancierd door BIJ12.

Wageningen Livestock Research

Wageningen, april 2022

Rapport 1296 
Hoving, I.E., G. Holshof, J.R. van der Schoot en R.F.A. Hendriks, 2022. Normbedragen extra herinzaai grasland door waterwinning. Wageningen Livestock Research, Rapport 1296.

Samenvatting NL

Naar aanleiding van claims in 2019 is in opdracht van de AdviesCommissie Schade Grondwater (ACSG) onderzoek gedaan naar de kosten voor extra herinzaai van grasland door droogtestress als gevolg van waterwinning. Door middel van modelberekeningen, literatuuronderzoek en analyse van grasrassenonderzoek is een schadedrempel voor herinzaai van grasland op droge zandgrond vastgesteld. Daarbij is de toename van herinzaai door extra droogtestress gekwantificeerd voor twee niveaus van grondwateronttrekking voor waterwinning. Het melkveeproefbedrijf De Marke (Hengelo GLG) dat in het waterwingebied 't Klooster ligt, is hierbij als uitgangspunt genomen. De toename van de opbrengstdepressie en de extra kosten voor herinzaai zijn vertaald in normbedragen voor extra herinzaai. Per procent opbrengstdepressie bedragen de kosten voor extra herinzaai door waterwinning $€$ 4,1 per ha per jaar, gegeven de gehanteerde tarieven.

Summery UK

In response to claims in 2019, a study was carried out on behalf of the Advisory Committee on Groundwater Damage (ACSG) into the costs of additional reseeding of grassland due to drought stress as a result of water extraction. A damage threshold for reseeding grassland on dry sandy soil has been established by means of model calculations, literature research and analysis of grass variety research. The increase in grassland renewal due to additional drought stress was quantified for two levels of groundwater extraction for drinking water extraction. Experimental dairy farm De Marke (Hengelo GLG) that is located in the water extraction area 't Klooster was taken as starting point. The increase in yield depression and the additional costs for renewal have been translated into standard amounts for additional grassland renewal. Per percent yield depression, the costs for additional reseeding through water extraction are $€ 4.1$ per ha per year, given the rates used.

Dit rapport is gratis te downloaden op https://doi.org/10.18174/541833 of op

www.wur.nl/livestock-research (onder Wageningen Livestock Research publicaties).

\section{(cc) BY-NC}

Dit werk valt onder een Creative Commons Naamsvermelding-Niet Commercieel 4.0 Internationaal-licentie.

(C) Wageningen Livestock Research, onderdeel van Stichting Wageningen Research, 2022

De gebruiker mag het werk kopiëren, verspreiden en doorgeven en afgeleide werken maken. Materiaal van derden waarvan in het werk gebruik is gemaakt en waarop intellectuele eigendomsrechten berusten, mogen niet zonder voorafgaande toestemming van derden gebruikt worden. De gebruiker dient bij het werk de door de maker of de licentiegever aangegeven naam te vermelden, maar niet zodanig dat de indruk gewekt wordt dat zij daarmee instemmen met het werk van de gebruiker of het gebruik van het werk. De gebruiker mag het werk niet voor commerciële doeleinden gebruiken.

Wageningen Livestock Research aanvaardt geen aansprakelijkheid voor eventuele schade voortvloeiend uit het gebruik van de resultaten van dit onderzoek of de toepassing van de adviezen.

Wageningen Livestock Research is NEN-EN-ISO 9001:2015 gecertificeerd.

Op al onze onderzoeksopdrachten zijn de Algemene Voorwaarden van de Animal Sciences Group van toepassing. Deze zijn gedeponeerd bij de Arrondissementsrechtbank Zwolle. 


\section{Inhoud}

Woord vooraf $\quad \mathbf{5}$

$\begin{array}{ll}\text { Samenvatting } & 7\end{array}$

$\begin{array}{lr}\text { Inleiding } & 9\end{array}$

2

$\begin{array}{ll}\text { Werkwijze } & 11\end{array}$

2.1 Droogtestress $\quad 11$

$\begin{array}{ll}2.2 & \text { Literaturonderzoek en modelberekeningen } \\ 2.3 & 11\end{array}$

$\begin{array}{ll}2.3 \text { Bedrijfsberekeningen } & 11\end{array}$

$\begin{array}{lll}2.4 & \text { Bodem en hydrologie } & 13\end{array}$

3

$\begin{array}{lr}\text { Methodiek } & 18\end{array}$

$\begin{array}{llr}3.1 & \text { Waterpas } & 18\end{array}$

$\begin{array}{llr}3.2 & \text { BBPR } & 18\end{array}$

$\begin{array}{lll}3.3 & \text { SWAP } & 19\end{array}$

$\begin{array}{lll}3.4 & \text { Grasgroei } & 21\end{array}$

$\begin{array}{ll}3.5 & \text { GLG en GHG } \\ 3.6 & 23\end{array}$

3.6 Verandering grasproductie na herinzaai 23

\begin{tabular}{|lll}
4 & Engels raaigras en droogtestress & 28
\end{tabular}

$\begin{array}{lll}4.1 & \text { Engels raai } & 28\end{array}$

$\begin{array}{lll}4.2 & \text { Droogte en persistentie } & 28\end{array}$

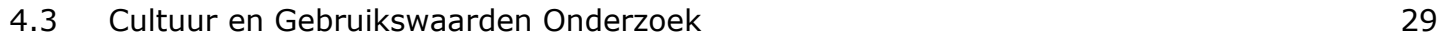

$\begin{array}{lll}4.4 & \text { Schadedrempel herinzaai } & 32\end{array}$

4.5 Extra herinzaai door toename droogtestress 33

$5 \quad$ Resultaten modelberekeningen 34

$\begin{array}{lll}5.1 & \text { Algemeen } & 34\end{array}$

$\begin{array}{lll}5.2 & \text { Grondwater en drukhoogte en draagkracht } & 34\end{array}$

5.2.1 Grondwaterstand $\quad 34$

$\begin{array}{lll}5.2 .2 \text { Drukhoogte } & 35\end{array}$

$\begin{array}{lll}5.3 & \text { Technische bedrijfsresultaten } & 36\end{array}$

$\begin{array}{ll}\text { 5.3.1 Grasproductie } & 36\end{array}$

$\begin{array}{lll}\text { 5.3.2 Droogteschade } & 36\end{array}$

$\begin{array}{ll}\text { 5.3.3 Verdeling grasopbrengst } & 37\end{array}$

5.3.4 Aandeel maaien eerste en overige sneden 38

$\begin{array}{ll}\text { 5.3.5 Zelfvoorziening ruwvoer } & 38\end{array}$

$\begin{array}{ll}\text { 5.3.6 Grasopname melkvee } & 39\end{array}$

6 Normbedragen extra herinzaai $\quad 4$

$\begin{array}{lll}6.1 & \text { Grasproductie extra herinzaai } & 41\end{array}$

$\begin{array}{lll}6.2 & \text { Kosten/baten extra herinzaai } & 43\end{array}$

7 Discussie $\quad 40$

$\begin{array}{lll}7.1 & \text { Persistentie Engels raai } & 46\end{array}$

$\begin{array}{lll}7.2 & \text { Resultaten modelberekeningen } & 46\end{array}$

$\begin{array}{lll}7.3 & \text { Normbedragen herinzaai } & 49\end{array}$

$\begin{array}{lr}\text { Conclusies } & 51\end{array}$ 
Bijlage 1 Grondwaterstanden

$\begin{array}{lll}\text { Bijlage } 2 \text { Drukhoogte wortelzone } & 59\end{array}$

Bijlage 3 Melk- en voerproductie $\quad 61$

$\begin{array}{lll}\text { Bijlage } 4 \text { Grasopname } & 64\end{array}$

Bijlage 5 Invoer HerinzaaiWijzer bij herinzaai eens in de 14 jaar 66

Bijlage 6 Grasopbrengstverloop bij herinzaai eens in de 14 jaar 68

Bijlage 7 Invoer HerinzaaiWijzer bij verhoogde herzaaifrequentie 74

Bijlage 8 Grasopbrengstverloop bij verhoogde herzaaifrequentie 76

Bijlage 9 Kosten herinzaai $\quad 8$

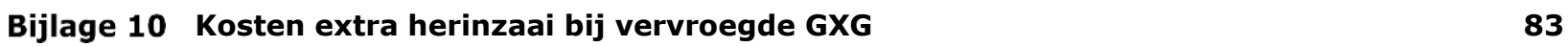




\section{Woord vooraf}

Claims in 2019 van kosten voor extra herinzaai door droogtestress als gevolg van waterwinning waren voor de AdviesCommissie Schade Grondwater (ACSG) aanleiding om onderzoek te laten doen naar de kosten van extra herinzaai binnen schadegebieden. Gevraagd werd een bedrag per ha vast te stellen dat afhankelijk is van de toename van de opbrengstdepressie, zo mogelijk boven een bepaalde drempel.

Door Wageningen Livestock Research is in samenwerking met Wageningen Plant Research en Wageningen Environmental Research onderzoek uitgevoerd om inzicht te krijgen in de hydrologische, technische en economische consequenties van extra droogte door waterwinning. Met dit rapport wordt beoogd een antwoord te geven op de gestelde onderzoeksvragen en meer inzicht te geven in de effecten van droogte op de productie en mate van herinzaai van grasland van een melkveebedrijf op droge zandgrond.

Het voorliggende rapport is een herziening van rapport 1296 zoals dat in maart 2021 is uitgebracht. De berekeningen voor het onderzoek zijn opnieuw uitgevoerd, naar aanleiding van reacties die waren binnengekomen van DNL, Vitens en Brabant Water. Na publicatie werd een fout ontdekt in de berekende hydrologie en verandering van de grasproductie na herinzaai. Deze onvolkomenheden bleken een behoorlijke invloed te hebben op de kosten voor extra herinzaai als gevolg door grondwaterwinning. Met de herberekening zijn de onvolkomenheden rechtgezet.

Dr. drs. I.D. de Wolf

Afdelingshoofd Veehouderij \& Omgeving, Wageningen Livestock Research 


\section{Samenvatting}

In opdracht van de AdviesCommissie Schade Grondwater (ACSG) zijn normbedragen vastgesteld voor de kosten van extra herinzaai als gevolg van extra droogtestress door waterwinning op een droge zandgrond. Door middel van modelberekeningen, literatuuronderzoek en een analyse van het CGO-grasrassenonderzoek is een schadedrempel voor herinzaai van grasland op droge zandgrond vastgesteld. Daarbij is de toename van herinzaai door extra droogtestress gekwantificeerd voor twee niveaus van grondwateronttrekking voor waterwinning. Hiervoor is melkveeproefbedrijf De Marke uit het waterwingebied 't Klooster als uitgangspunt genomen. De toename van de opbrengstdepressie en de extra kosten voor herinzaai zijn vertaald in normbedragen voor extra herinzaai. De kosten voor herinzaai zonder wateronttrekking gelden hierbij als drempelwaarde.

Uit data van het Cultuur en Gebruikswaarden Onderzoek (CGO) betreffende de ontwikkeling van de opbrengst, grasbezetting en aandeel Engels raaigras, werd een relatie afgeleid tussen de afname van de bezetting van Engels raaigras en de toename van droogtestress. De standaard vermindering van de grasbezetting gedurende een lange periode is als uitgangspunt genomen voor het vinden van een opbrengstdepressiepercentage waar beneden de frequentie voor herinzaai niet varieert (drempelwaarde). De drempelwaarde voor het herinzaaipercentage voor zandgrond bedroeg 7,1\% (eens in de 14 jaar). De gevonden verminderde grasbezetting bij extreme droogte in 2018-2019 op zandgrond is vertaald in extra herinzaai door extra droogte door grondwaterwinning. Dit resulteerde in een herinzaaipercentage voor maximale droogtestress van $16,7 \%$ (eens in de 6 jaar).

De opbrengstreductie door extra droogtestress is modelmatig berekend met het Waterpasinstrumentarium voor twee bodemtypen (leemarm en zwaklemig fijn zand met een humeus dek van $30 \mathrm{~cm}$ ) en drie verschillende gradaties van droogtestress, namelijk een referentiesituatie en twee niveaus van grondwateronttrekking. Met Waterpas kan een melkveebedrijf integraal doorgerekend worden op basis van bodemtextuur, hydrologische kenmerken en bedrijfstypering. De droogteschade is berekend voor de weerjaren 2000-2019. Deze reeks representeert een brede variatie aan typen weerjaren variërend van nat tot zeer droog en daarmee is de mate van droogtestress en de variatie tussen weerjaren in beeld gebracht. De opbrengstdepressie varieerde van 11,3 tot $32,2 \%$.

De modelberekeningen gaven een objectieve vertaling van vochttekort in groeireductie en opbrengstniveaus en benaderden de orde van grootte van gemeten grasopbrengsten op De Marke. Per weerjaar was de variatie tussen de gemeten opbrengsten veelal groter dan de variatie tussen de berekende opbrengsten van de droogtevarianten.

De herinzaaipercentages voor de drempelwaarde en de maximale droogtestress betroffen het bereik waarbinnen de opbrengstdepressiepercentages vallen die volgden uit de bedrijfsberekeningen. Zodoende is gesteld dat voor de laagst berekende opbrengstdepressie van 11,3\% (of minder) het herinzaaipercentage $7,1 \%$ bedraagt. Dit betekent, dat zolang dit opbrengstdepressiepercentage niet wordt overschreden, herinzaai eens in de 14 jaar plaatsvindt. De hoogst berekende opbrengstdepressie van $32,2 \%$ is gerelateerd aan het herinzaaipercentage $16,7 \%$, dat overeenkomt met herinzaai eens in de zes jaar. Door middel van interpolatie zijn de herinzaaifrequenties voor de overige varianten berekend.

De kosten voor herinzaai zijn berekend met het model Herinzaaiwijzer aan de hand van de vastgestelde herinzaai- en de opbrengstdepressiepercentages. Hierbij is niet alleen uitgegaan van extra herinzaai, maar ook van de kosten voor het verlies van de eerste snede na herinzaai en de extra opbrengst van nieuw gras in de sneden en jaren na herinzaai. Het verschil in kosten is vertaald in normbedragen voor extra herinzaai.

De extra herinzaai vertaalde zich in een toename van kosten, echter ook de verminderde grasopbrengst door droogte brengt extra kosten met zich mee, vooral in de vorm van de aankoop van extra ruwvoer. Het berekenen van deze kosten vielen buiten het kader van het onderzoek en zijn buiten beschouwing gebleven. 
De normbedragen voor extra herinzaai afhankelijk van de berekende opbrengstdepressie staan in Tabel 1. De normbedragen bestaan uit de directe kosten voor herinzaai en een waardevermindering van de netto grasopbrengst gemiddeld over de herinzaaiperiode.

Tabel 1 Normbedragen extra herinzaai door waterwinning op een relatief droge zandgrond in relatie tot opbrengstdepressie bestaande uit directe kosten voor herinzaai en een gemiddelde waardevermindering van de netto grasopbrengst (euro. ha-1.jaar-1).

\begin{tabular}{|c|c|c|c|c|}
\hline \multirow[t]{2}{*}{ Variant } & \multirow[t]{2}{*}{$\begin{array}{c}\text { Opbrengst-depressie } \\
(\%)\end{array}$} & \multicolumn{3}{|c|}{$\begin{array}{c}\text { Kosten in relatie tot opbrengstdepressie } \\
\left.\text { (euro.ha-1.jaar }{ }^{-1}\right)\end{array}$} \\
\hline & & Herinzaai & Grasopbrengst & Normbedrag \\
\hline \multicolumn{5}{|l|}{ Zwak lemig } \\
\hline Referentie & 11,3 & 0 & 0 & 0 \\
\hline Waterwinning 1 & 21,8 & 24 & 10 & 34 \\
\hline Waterwinning 2 & 28,1 & 44 & 14 & 58 \\
\hline \multicolumn{5}{|l|}{ Leemarm } \\
\hline Referentie & 20,5 & 24 & 29 & 53 \\
\hline Waterwinning 1 & 29,7 & 44 & 32 & 75 \\
\hline Waterwinning 2 & 32,2 & 58 & 37 & 95 \\
\hline
\end{tabular}

De kosten voor extra herinzaai in relatie tot de opbrengstdepressie uit Tabel 1 staan eveneens in Figuur 1.1. Met trendlijnen zijn de relaties tussen de opbrengstdepressie en de kosten weergegeven. Per procent opbrengstschade bedragen de kosten voor extra herinzaai door waterwinning $€$ 4,1 per ha per jaar, gegeven de gehanteerde tarieven. Daarvan bedragen de kosten voor herinzaai $€ 2,64$ en het verlies aan grasproductie $€ 1,46$ per ha per jaar.

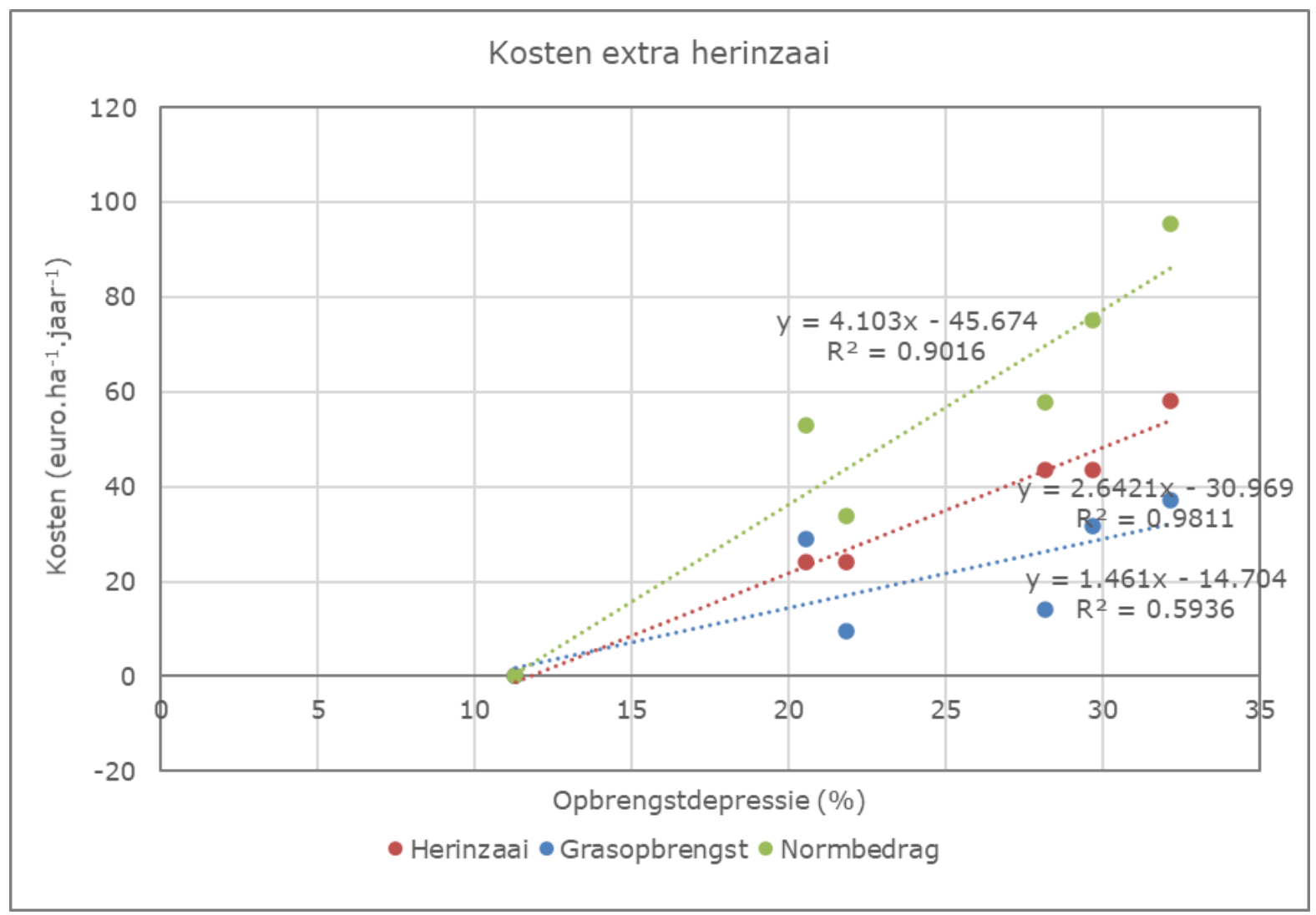

Figuur 1.1 Kosten extra herinzaai (euro.ha-1.jaar-1) door waterwinning op een relatief droge zandgrond in relatie tot de opbrengstdepressie voor grasland, met onderscheid tussen de directe kosten voor herinzaai, het waardeverlies van de netto grasopbrengst en de normbedragen als totaal hiervan. Voor de normbedragen staat de functie vermeld. 


\section{$1 \quad$ Inleiding}

Herinzaai van blijvend grasland is aan de orde wanneer de grasopbrengst achterblijft en de voederwaarde achteruitgaat. Een verminderde grasopname bij het weiden van vee door toename van het aandeel grassoorten dat slecht gevreten wordt is hierbij een belangrijk aspect. Ook open plekken reduceren de grasopbrengst. Door droogte gaat het aandeel gewenste grassen en de dichtheid van de graszode achteruit. Wanneer dit niet herstelt en de graszode te weinig productief is dan vindt herinzaai plaats. Volgens het huidige advies (Hoving et al., 2006) is graslandvernieuwing aan de orde, wanneer de botanische samenstelling van de graszode te sterk is achteruitgegaan en herstel uitgesloten is. De criteria voor een onvoldoende botanische samenstelling van de zode zijn als volgt:

- $\quad<50 \%$ Engels raaigras

- $\quad$ of $>10 \%$ kweek in haarden

- of $>20 \%$ kweek verspreid

Bij een dergelijke kwaliteit van de graszode wegen veelal de kosten van herinzaai op tegen de productieverbetering van een nieuwe graszode.

Droogte kan aanleiding zijn voor een directe afname van het aandeel Engels raaigras en een toename van ongewenste grassen, vooral wanneer droogte meerdere jaren achter elkaar voorkomt. Op droge zandgronden betreft dit vooral de toename van kweek en straatgras. De relatie tussen het negatieve effect van droogtestress en het aandeel slechte grassen is echter onbekend. Daarbij vergroot een hoger aandeel maaien het risico op het toenemen van het aandeel kweekgras. Een hoger maaiaandeel zou een indirect gevolg kunnen zijn van droogtestress.

Verdere toename van de droogtestress, bijvoorbeeld door toedoen van een grondwaterwinning, noodzaakt mogelijk sneller tot herinzaai en verhoogt daarmee de indirecte schade van droogte.

Het doel van het onderzoek, dat in het voorliggende rapport staat beschreven, is om een onderbouwing te geven voor een normbedrag voor de kosten van extra herinzaai als gevolg van extra droogtestress door waterwinning. Gewenst is om een bedrag per ha vast te stellen dat afhankelijk is van de toename van de opbrengstdepressie, zo mogelijk boven een bepaalde drempel.

Om hiertoe te geraken zijn de volgende onderzoeksvragen geformuleerd:

1. Kan een opbrengstdepressiepercentage worden vastgesteld waar beneden de frequentie voor herinzaai bij grasland op melkveehouderijbedrijven niet varieert met de verandering van dit opbrengstdepressiepercentage en wat is dan deze (gebruikelijke) frequentie? Gezocht wordt naar een drempelwaarde waarboven het herinzaaipercentage toeneemt als gevolg van extra droogteschade door waterwinning.

2. Wat is, als de eerste vraag positief beantwoord kan worden, de relatie tussen de toename van het opbrengstdepressiepercentage en de frequentie van herinzaai voor situaties waarin sprake is van opbrengstdepressiepercentages die groter zijn dan bedoeld bij vraag 1 ?

3. Hoe is deze relatie als de gezochte 'drempelwaarde' niet aanwezig blijkt? Wat zijn de kosten voor deze toename van frequentie van herinzaai?

Om de vragen zo objectief mogelijk te beantwoorden is een literatuurstudie uitgevoerd, is een grasrassenonderzoek geanalyseerd en zijn integrale bedrijfsberekeningen uitgevoerd waarbij de grasopbrengst afhankelijk gesteld is aan de mate van droogte voor een reeks van 20 weerjaren voor een leemarme en een zwak lemige bovengrond. 
De herinzaaifrequentie is bepaald in relatie tot droogtestress en de studie geeft inzicht in de hoogte van grasopbrengsten, de variatie in opbrengsten tussen weerjaren. Uit de herinzaaifrequenties en de gemiddelde opbrengstniveaus zijn normbedragen voor extra herinzaai berekend. 


\section{Werkwijze}

\section{$2.1 \quad$ Droogtestress}

Het begrip droogte is lastig te definiëren, omdat het volgens Wilhite and Glantz (1985) vanuit meerdere gezichtspunten bekeken kan (en moet) worden. Zij onderscheiden op basis van disciplinair perspectief vier typen droogte te weten meteorologisch, landbouwkundig, hydrologisch en sociaaleconomisch. In deze studie gaat het om de landbouwkundige droogte die betrekking heeft op blijvend grasland en tot uiting komt in de vorm van stress door vochttekort. Door vochttekort vermindert de groei, sterven spruiten af en kunnen gehele planten doodgaan, waardoor open plekken in de zode ontstaan. In de praktijk gaat in de zomer een watertekort vaak gepaard met hoge temperaturen $\left(>25^{\circ} \mathrm{C}\right)$ waardoor stress door droogte en door hitte moeilijk te onderscheiden zijn.

\subsection{Literatuuronderzoek en modelberekeningen}

Bepalen herinzaaifrequentie in relatie tot droogtestress

Door middel van literatuuronderzoek is onderzocht in hoeverre de persistentie van Engels raaigras gerelateerd is aan droogtestress. Daarbij is eveneens een analyse gedaan op de data van het Cultuur en Gebruikswaarden Onderzoek (CGO) naar de ontwikkeling van de opbrengst, grasbezetting en aandeel Engels raaigras in relatie tot droogte. De standaard vermindering van de grasbezetting en het aandeel Engels raaigras gedurende een lange periode is als uitgangspunt genomen voor het beantwoorden van de eerste onderzoeksvraag, namelijk het vinden van een opbrengstdepressiepercentage waar beneden de frequentie voor herinzaai niet varieert (drempelwaarde). De gevonden verminderde grasbezetting en het aandeel Engels raaigras bij extreme droogte is vertaald in extra herinzaai bij extra droogte door grondwaterwinning.

\section{Bepalen droogtestress}

Droogtestress uit zich in een toename van directe schade in de vorm van lagere grasopbrengsten en indirecte schade door beperkingen in het graslandgebruik. Om de opbrengstreductie door extra droogtestress te bepalen is in deze studie voor drie verschillende hydrologische condities en twee bodemtypen (leemarm en zwaklemig fijn zand met een humeus dek van $30 \mathrm{~cm}$ ) de mate van droogtestress gesimuleerd met het Waterpasinstrumentarium (zie volgende paragraaf en Hoofdstuk 3). Met dit instrumentarium is de directe en indirecte schade berekend voor drie gradaties van droogtestress voor een reeks van 20 weerjaren, te weten 2000-2019. Deze reeks representeert een brede variatie aan typen weerjaren variërend van nat tot zeer droog en daarmee wordt de mate van droogtestress en de variatie tussen weerjaren in beeld gebracht.

\section{Bepalen van normbedragen}

Met het model Herinzaaiwijzer (Hoving, 2006) zijn aan de hand van de vastgestelde herinzaaifrequenties en de gereduceerde grasopbrengsten door extra droogtestress de kosten van extra herinzaai berekend. Hierbij is niet alleen uitgegaan van de extra herinzaai, maar ook van de kosten voor het verlies van de eerste snede na herinzaai en de extra opbrengst van nieuw gras in de sneden en jaren na herinzaai. Het verschil in kosten is vertaald normbedragen voor extra herinzaai. Zie voor een nadere toelichting van de Herinzaaiwijzer Hoofdstuk 3.

\subsection{Bedrijfsberekeningen}

Om de effecten van de mate van droogte op de bedrijfsvoering te bepalen zijn integrale bedrijfsberekeningen uitgevoerd met het Waterpas instrumentarium (De Vos et al. 2006). Dit instrumentarium betreft een modelkoppeling tussen het BedrijfsbegrotingProgrammaRundveehouderij (BBPR; Schils et al. 2007) en het hydrologische model SWAP (Kroes et al., 2017). Hiermee kunnen alle 
bedrijfsaspecten van een melkveebedrijf, zoals voeding, bemesting, grasgroei, graslandgebruik en melkproductie geïntegreerd doorgerekend worden. Dit maakt het mogelijk om praktische bedrijfssituaties realistisch te benaderen. Door een reeks van verschillende weerjaren door te rekenen worden invloeden van verschillende meteorologische omstandigheden op grondgebruik en productie zichtbaar. Niet alleen een gemiddeld effect op de bedrijfsuitkomsten is een belangrijk gegeven, maar ook de variatie ten opzichte van het gemiddelde. Een grotere variatie betekent een hoger risico op jaren met een slecht bedrijfsresultaat, wat door ondernemers als bijzonder negatief ervaren wordt.

Proefbedrijf De Marke is als uitgangspunt gebruikt voor de modelberekeningen, omdat van dit bedrijf zeer veel data beschikbaar is, waardoor de modelinvoer beter onderbouwd kon worden en de uitkomsten beter te interpreteren zijn. Wel zijn de basisgegevens enigszins aangepast om een eenvoudiger vertaling naar zowel het model als de praktijk te maken. Zo zijn melkproductie en aantallen dieren afgerond naar gehele getallen en is de bodemclassificatie voor grasland binnen één berekening voor 20 weerjaren beperkt tot één bodemtype geldend voor het gehele bedrijf, terwijl dit in werkelijkheid varieert. De praktijksituatie is zoveel mogelijk in het model opgenomen. In Tabel 2 zijn de uitgangspunten van het modelbedrijf weergegeven.

Tabel 2 Uitgangspunten modelberekeningen gebaseerd op melkveeproefbedrijf De Marke.

\begin{tabular}{lr}
\hline Uitgangspunten & Data \\
\hline Bedrijfsoppervlakte (ha cultuurgrond) & 70 \\
\hline - huiskavel gras (ha) & 45 \\
\hline - veldkavel maaien (ha) & 11 \\
\hline - veldkavel snijmaïs (ha) & 14 \\
\hline - beheergrasland (ha) & 0 \\
\hline - extensief grasland (ha) & 0 \\
\hline Aantal melkkoeien (\#) & 140 \\
\hline Aantal pinken (\#) & 48 \\
\hline Aantal kalveren (\#) & 51 \\
\hline Melkproductie (normatief berekend; kg/koe/jaar) & 8750 \\
\hline Vetgehalte (\%) & 4,28 \\
\hline Eiwitgehalte (\%) & 3,46 \\
\hline krachtvoergebruik (kg per koe, exclusief jongvee) & 2500 \\
\hline Bijproducten (kg ds/koe/jaar) & 0 \\
\hline Stikstofjaargift grasland (80\% advies, berekend; kg N /ha totaal) & 235 \\
\hline Zelfvoorzieningsgraad ruwvoer (berekend; \%) & 70 \\
\hline Maaipercentage totaal (berekend; \%) & 235 \\
\hline
\end{tabular}

De berekeningen zijn uitgevoerd voor een leemarme en een zwak lemige bovengrond (verschillen in droogtegevoeligheid, zie volgende paragraaf) in vier situaties, waarbij de potentiële grasproductie is vergeleken met een situatie zonder grondwateronttrekking en een situatie met grondwateronttrekking in twee gradaties. Hiermee zijn verschillende maten van droogtestress gesimuleerd:

1) Potentiële grasproductie (Potentieel)

2) Grasproductie zonder grondwateronttrekking (Referentie)

3) Grasproductie bij middelmatige grondwateronttrekking (Waterwinning 1)

4) Grasproductie bij grote grondwateronttrekking (Waterwinning 2)

De potentiële productie betreft de grasproductie gegeven de beschikbare stikstof uit bemesting (kunstmest en drijfmest) en mineralisatie van organische stof uit de bodem, zonder stress door droogte, vernatting of nadeel door graslandgebruiksbeperkingen als gevolg van vernatting. De varianten zijn doorgerekend zonder toepassing van herinzaai.

Voor wat betreft de bedrijfseconomische kengetallen is uitgegaan van de meest actuele prijzen en tarieven uit de KWIN-veehouderij (2019-2020). 


\subsection{Bodem en hydrologie}

Wageningen Environmental Research (WEnR) leverde de inputfiles voor SWAP voor de specifieke bodemkundige en hydrologische situatie van proefbedrijf De Marke dat model heeft gestaan voor droogtegevoelige zandgronden met diepe grondwaterstanden. Van de nabijgelegen drinkwaterwinning 't Klooster waren grondwatermodelberekeningen beschikbaar die Arcadis heeft uitgevoerd voor Vitens (ARCADIS, 2019). In het rapport van deze studie is een peilbuis, B34C0150_1, voor het meten van de stijghoogten van het diepere grondwater opgenomen die op 400 meter van het proefbedrijf staat (Figuur 2.1). Het rapport geeft gesimuleerde stijghoogten van verschillende modelscenario's voor deze buis. Deze zijn in berekeningen met SWAP gebruikt om verdrogingsscenario's te simuleren.

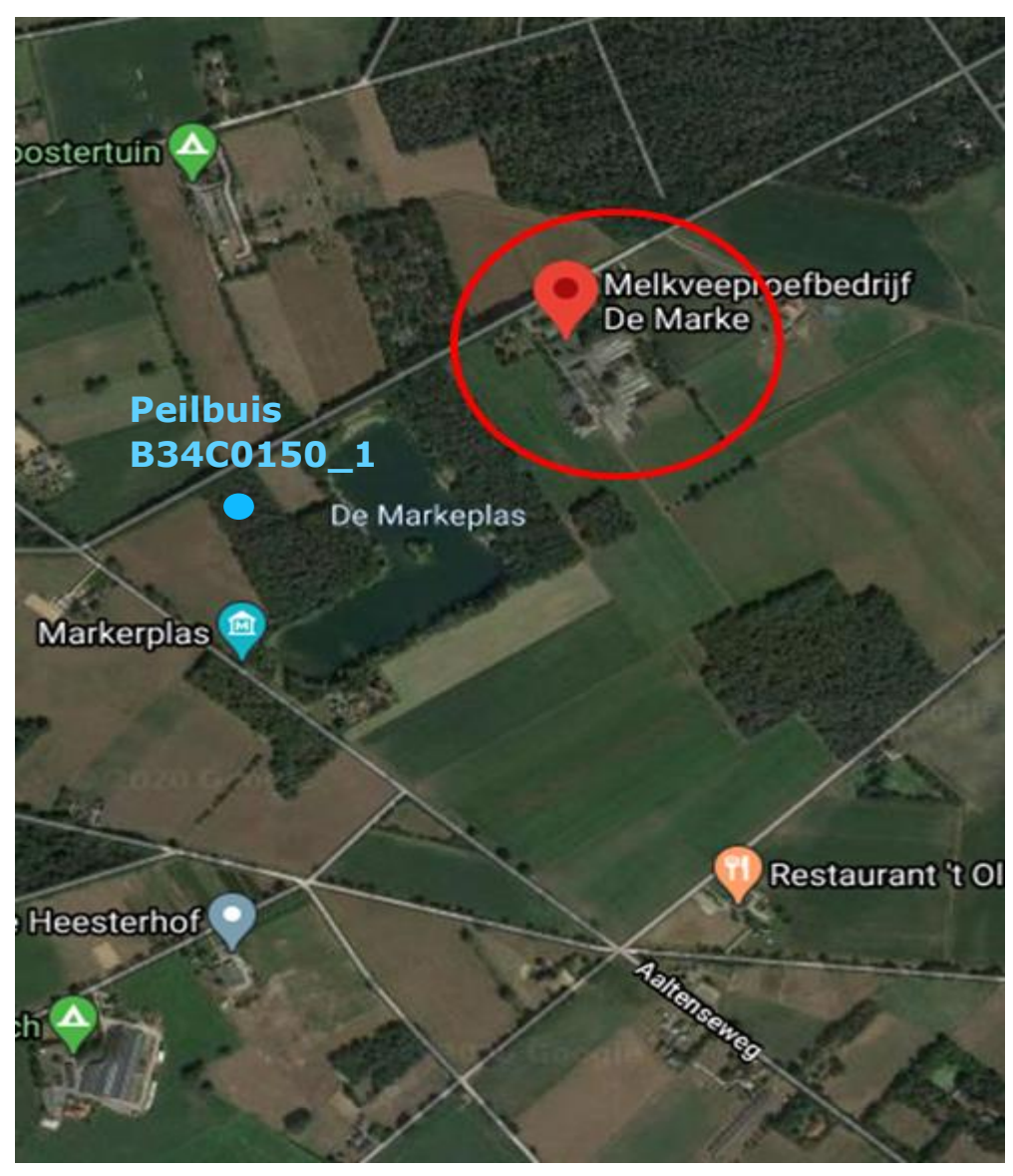

Figuur 2.1 Ligging van melkveeproefbedrijf De Marke en peilbuis B34C0150_1Bodem.

De dominante bodemeenheden op het bedrijf zijn de veldpodzolen Hn43 en Hn51 (Dekkers, 1992). De eerste bestaat uit zwak lemig, zeer fijn en matig fijn zand en de tweede uit leemarm, matig fijn zand. Onderscheid tussen deze twee eenheden is relevant voor het onderzoek, want leemarm zand heeft een geringere capaciteit voor capillaire nalevering uit de verzadigde zone en is daardoor gevoeliger voor droogte in de wortelzone dan zwaklemig zand. Daarbij heeft een leemarme humeuze bovengrond een lager vochtleverend vermogen dan een zwaklemige humeuze bovengrond. Om die redenen zijn beide eenheden opgenomen in het onderzoek en dus in de SWAP-berekeningen.

Voor de berekeningen met SWAP is het nodig om de bodemkolom onder te verdelen in bodemhorizonten waaraan belangrijke bodemeigenschappen als de hydraulische karakteristieken waterretentie- en doorlatendheidskarakteristiek worden toegekend. In deze berekeningen zijn voor beide bodemeenheden slechts twee horizonten onderscheiden: een $30 \mathrm{~cm}$ dikke wortelzone waaronder een ondergrond tot $400 \mathrm{~cm}$ diepte. De horizonten zijn voor de numerieke berekeningen weer onderverdeeld in bodemcompartimenten van $1 \mathrm{~cm}$ (eerste $50 \mathrm{~cm}), 2 \mathrm{~cm}(50-100 \mathrm{~cm}$ diep), $5 \mathrm{~cm}(100-200 \mathrm{~cm}$ diep) tot $10 \mathrm{~cm}(200-400 \mathrm{~cm}$ diep) dik.

De hydraulische karakteristieken van de vier onderscheiden bodemhorizonten zijn niet gemeten, maar de waarden zijn betrokken van de Bouwstenen van de Staringreeks 1987 (Wösten et al., 1987). Voor 
bodemeenheid Hn43 met zwaklemig zand zijn Bouwstenen B2 voor de wortelzone en O2 voor de ondergrond gebruikt; voor eenheid Hn51 met leemarm zand zijn dat respectievelijk Bouwstenen B1 en O1. Hack-ten Broeke en Hegmans (1996) vonden voor proefbedrijf De Marke statistisch even goede modelresultaten voor vochtgehalten en drukhoogten gesimuleerd met Bouwstenen van de Staringreeks als voor simulaties met gemeten hydraulische karakteristieken.

\section{Hydrologie}

Uit dwarsdoorsneden van het AHN3 blijkt dat op het proefbedrijf geen sloten aanwezig zijn en dit werd door de bedrijfsleiding van De Marke bevestigd. De ontwatering van de percelen vindt plaats door wegzijging naar het diepere grondwater (Dekkers, 1992). Volgens Dekkers (1992) heeft het grootste deel van het proefbedrijf grondwatertrap (Gt) VIId met een GHG (gemiddeld hoogste grondwaterstand) van $80-140 \mathrm{~cm}-$ $\mathrm{mv}$ en een GLG (gemiddeld laagste grondwaterstand) van 180-250 cm -mv. Dit gegeven is gebruikt om een globale kalibratie uit te voeren voor de wegzijging met de c-waarde als de gekalibreerde parameter.

Wegzijging is gemodelleerd als het potentiaalverschil tussen grondwaterstand en stijghoogte van het diepere grondwater gedeeld door de weerstand tegen verticale stroming (c-waarde).

De dynamiek in de tijd van de stijghoogte is verkregen door een sinus te fitten door de meetwaarden van peilbuis B34C0150_1 van de periode 2003-2017 (vanaf augustus 2017 wordt deze buis niet meer bemeten). Deze gegevens zijn betrokken van het DINOloket. Figuur 2.2 geeft het resultaat van deze fit. De gemiddelde stijghoogte van de fit bedraagt $236,6 \mathrm{~cm}-\mathrm{mv}$, de halfamplitude $71,5 \mathrm{~cm}$ en het dagnummer in het kalenderjaar met de maximale stijghoogte 71,4 .

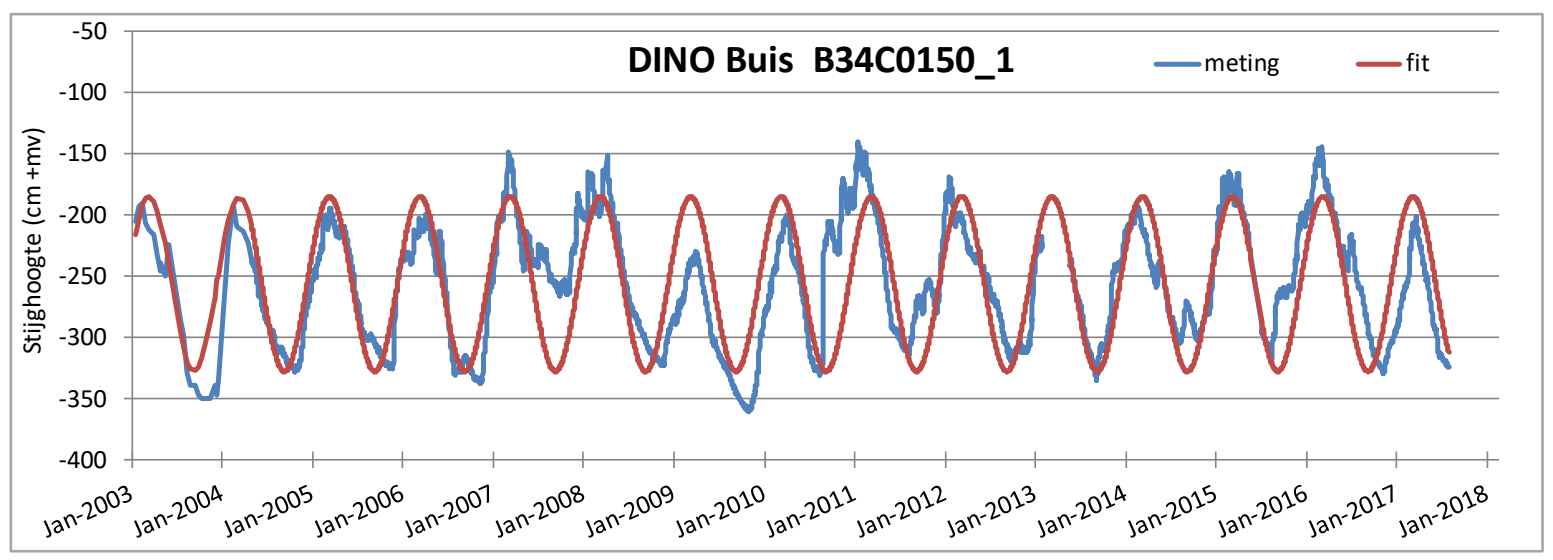

Figuur 2.2 Resultaten van het fitten van het stijghoogteverloop met een sinus door de gemeten waarden van peilbuis B34C0150_1. Gemeten waarden van het DINOloket.

De c-waarde is gekalibreerd door via trial-and-error een waarde te vinden waarbij de berekende GHG en GLG lagen binnen het bereik dat Dekkers (1992) geeft voor deze Gt-variabelen (zie boven). GHG en GLG zijn hierbij op de standaardmanier berekend uit de gesimuleerde grondwaterstanden van de gehele 30-jarige simulatieperiode. Tabel 3 geeft de resultaten van de kalibratie voor beide bodemprofielen. Het model dat op deze manier is opgesteld, is het Referentiemodel.

Tabel 3 Kalibratieresultaten van de twee bodemprofielen voor de referentiesituatie.

\begin{tabular}{lccc}
\hline Bodemprofiel & $\begin{array}{c}\text { Gekalibreerde } \\
\text { c-waarde (dagen) }\end{array}$ & GHG (cm - mv) & GLG (cm - mv) \\
\cline { 3 - 4 } & 500 & 134 & 255 \\
\hline $\mathrm{Hn} 43$ & 500 & 138 & 245 \\
\hline
\end{tabular}

Scenario's van verdroging

Naast het Referentiemodel 'droog' zijn nog twee scenariomodellen opgesteld waarmee twee gradaties van een sterkere verdroging zijn gesimuleerd te weten 'middel droog' en 'zeer droog'. Modelmatig zijn deze twee scenario's verwezenlijkt door de stijghoogte te verlagen met behoud van de c-waarde. De verlagingen van beide scenario's zijn gebaseerd op de door Arcadis gesimuleerde stijghoogten van peilbuis B34C0150_1 voor 
de twee scenario's SC0 en SC1 (ARCADIS, 2019). SC1 is het 'huidige situatie' scenario van Arcadis waaraan het grondwatermodel is getoetst. SCO is het scenario 'huidige situatie zonder infiltratievoorziening'.

Figuur 2.3 boven laat zien dat de modelresultaten van scenario SC1 vooral in 2014-2016 de gemeten waarden redelijk sterk onderschatten. De peilbuis viel in de klasse '10-20 cm onderschatting van de gemeten waarden' van de Arcadis-modellering. Juist door deze onderschatting is het gesimuleerde verloop nuttig om als uitgangspunt van een verdrogingsscenario te nemen. Het voordeel van het nemen van door een grondwatermodel gesimuleerde stijghoogteverlopen als basis voor verdrogingsscenario's in plaats van de stijghoogte een aantal centimeters te verlagen, is dat zowel de orde van grootte van de verlaging als de dynamiek in termen van hoogste en laagste waarde (de amplitude) meer realistisch zijn gefundeerd. Dat geldt vooral ook voor het verschil tussen SC1 en SC0: wel of geen infiltratievoorziening. Daarnaast ligt het stijghoogteverloop van SC1 ruwweg midden tussen 'gemeten' en SC0, waardoor dit een 'middel droogscenario' vertegenwoordigt.

De waarden van de twee sinus-variabelen 'gemiddelde stijghoogte' en 'halfamplitude' zijn voor beide verdrogingsscenario's verkregen door de verschillen tussen de gemeten stijghoogtelijnen en de lijnen van de twee scenario's SC0 en SC1 voor de jaren 2014-2016 te middelen. Tabel 4 geeft de daaruit verkregen sinuswaarden. De verkregen stijghoogteverlopen zijn weergegeven in Figuur 2.3. Voor het dagnummer in het kalenderjaar met de maximale stijghoogte is de waarde van de referentie genomen. Tabel 4 geeft ook voor beide verdrogingsscenario's en voor beide bodemprofielen de resulterende SWAP-uitkomsten van het grondwaterloop in termen van GHG en GLG.

Tabel 4 Waarden van de sinusvariabelen voor de twee scenario's 'Waterwinning 1' (SC1) en 'Waterwinning 2' (SCO), en de hiermee gesimuleerde GHG en GLG voor beide bodemprofielen.

\begin{tabular}{|c|c|c|c|c|c|c|c|}
\hline \multirow{3}{*}{$\begin{array}{l}\text { Verdrogings- } \\
\text { scenario }\end{array}$} & \multirow{3}{*}{$\begin{array}{l}\text { Scenario uit } \\
\text { ARCADIS } \\
\text { (2019) }\end{array}$} & \multicolumn{2}{|c|}{ Waarden sinus } & \multicolumn{4}{|c|}{ Gt-waarden (cm -mv) } \\
\hline & & \multirow[t]{2}{*}{$\begin{array}{l}\text { Gemiddelde stijghoogte } \\
\text { (cm -mv) }\end{array}$} & \multirow[t]{2}{*}{$\begin{array}{l}\text { Halfamplitude } \\
(\mathrm{cm})\end{array}$} & \multicolumn{2}{|c|}{$\begin{array}{c}\text { Hn43 } \\
\text { (zwak lemig) }\end{array}$} & \multicolumn{2}{|c|}{$\begin{array}{c}\text { Hn51 } \\
\text { (leemarm) } \\
\end{array}$} \\
\hline & & & & GHG & GLG & GHG & GLG \\
\hline Waterwinning 1 & $\mathrm{SC} 1$ & 264,6 & 55 & 169 & 275 & 170 & 264 \\
\hline Waterwinning 2 & sco & 289,1 & 53 & 194 & 296 & 195 & 286 \\
\hline
\end{tabular}

In de SWAP-berekeningen van de referentie en de twee verdrogingsscenario's is geen beregening meegenomen.

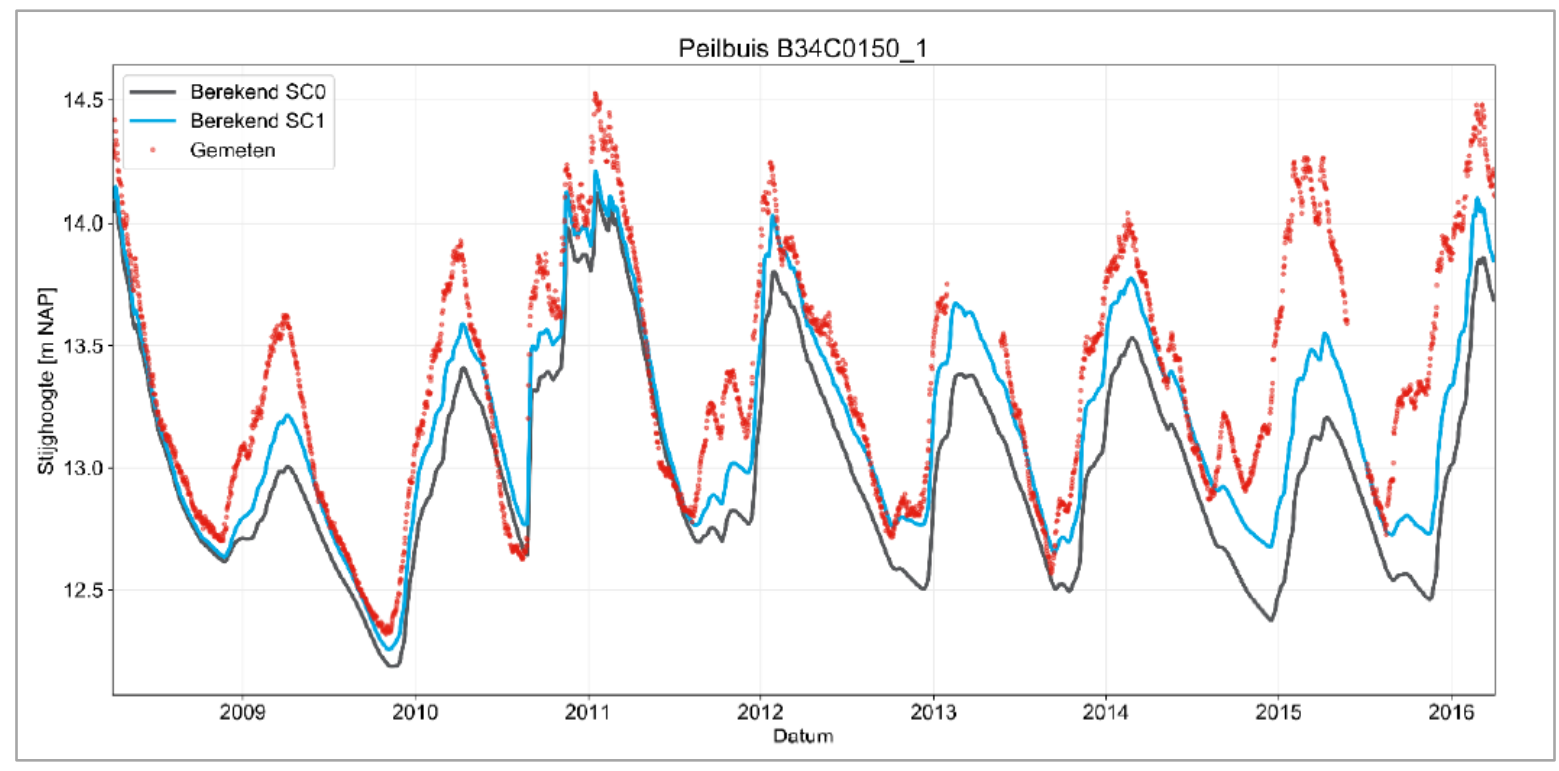




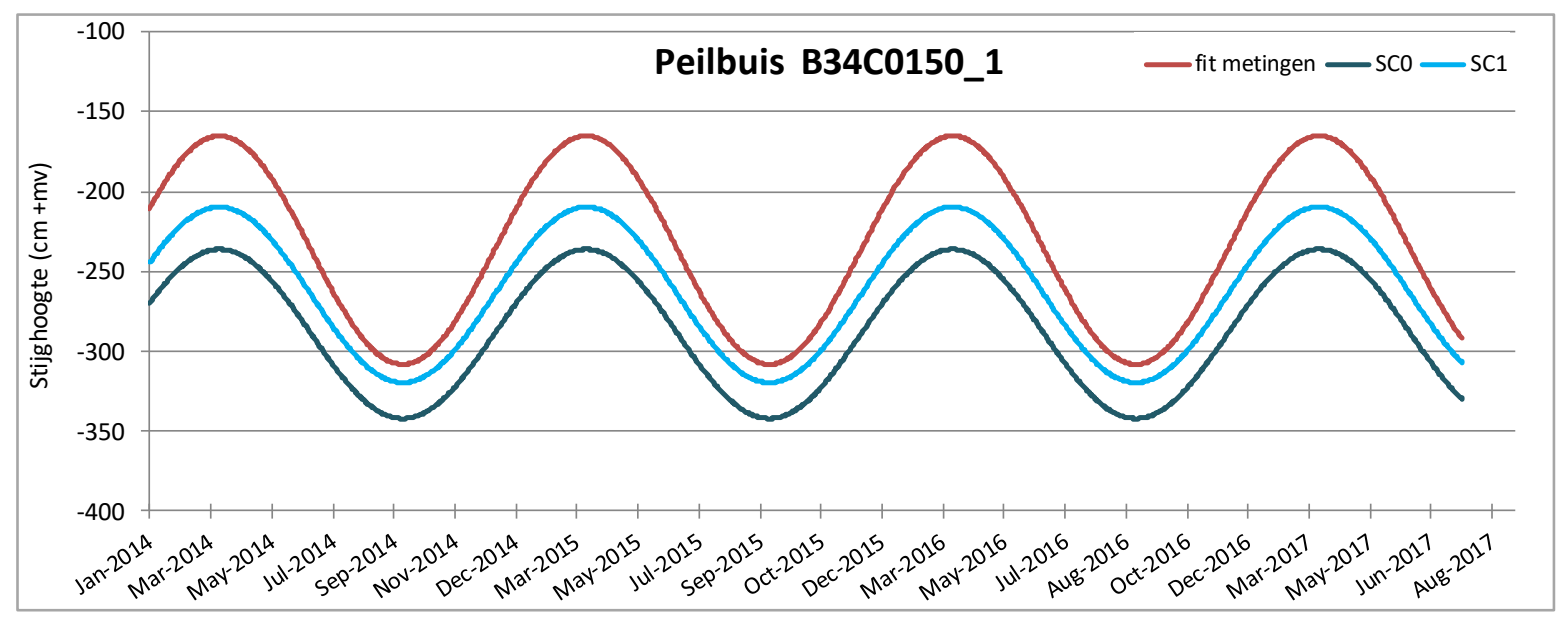

Figuur 2.3 Boven: gemeten en door Arcadis gesimuleerde stijghoogteverloop van peilbuis B34C0150_1 (uit: ARCADIS, 2019). Onder: sinusvormig stijghoogteverloop gebruikt in de SWAPberekeningen voor de referentie (fit metingen) en twee verdrogingsscenario's. Voor scenariocoden SCO en SC1, zie tekst.

Weer

Voor de berekeningen is een reeks van twintig weerjaren doorgerekend om het effect van verschillende weerjaren op het bedrijfsresultaat in beeld te brengen. Gekozen is voor de weerjaren 2000-2019, waarin de meest uiteenlopende weersituaties vertegenwoordigd zijn, variërend van relatief nat tot relatief droog. In Tabel 5 staat de neerslag - verdamping (neerslagtekort) in $\mathrm{mm}$ per maand per jaar. Daarbij zijn de neerslagdata betrokken van het neerslagstation Hengelo (Gelderland; KNMI station 645) en de Makkinkverdamping (ETref) van het weerstation Hupsel (KNMI station 283).

Tabel $5 \quad$ Neerslag - verdamping in mm per maand per jaar (2000-2019) gebaseerd op neerslag van neerslagstation Hengelo (Gelderland; KNMI station 645) en de Makkinkverdamping (ETref) van weerstation Hupsel (KNMI station 283).

\begin{tabular}{|c|c|c|c|c|c|c|c|c|c|c|c|c|c|}
\hline Maand & 1 & 2 & 3 & 4 & 5 & 6 & 7 & 8 & 9 & 10 & 11 & 12 & Jaar \\
\hline 2000 & 7 & 17 & 25 & 61 & 93 & 103 & 70 & 89 & 45 & 24 & 12 & 8 & 551 \\
\hline 2001 & 18 & 66 & 50 & 53 & -28 & -58 & -63 & -22 & 68 & 34 & 68 & 29 & 215 \\
\hline 2002 & 50 & 51 & 2 & 34 & 27 & -17 & -50 & -46 & -2 & 68 & 94 & 86 & 295 \\
\hline 2003 & 52 & 20 & 49 & -15 & -24 & -34 & -60 & -9 & 24 & 29 & 80 & 66 & 179 \\
\hline 2004 & 7 & 15 & 35 & 66 & 78 & 88 & 93 & 85 & 62 & 30 & 11 & 6 & 575 \\
\hline 2005 & 16 & 34 & 61 & 18 & 27 & -1 & -33 & -75 & 65 & 26 & 125 & 45 & 307 \\
\hline 2006 & 69 & 25 & 60 & 28 & 7 & -64 & -30 & 0 & 6 & 34 & 96 & 66 & 298 \\
\hline 2007 & 48 & 32 & 19 & -58 & -34 & -34 & -28 & -69 & -13 & 53 & 124 & 36 & 75 \\
\hline 2008 & 9 & 18 & 33 & 62 & 91 & 90 & 100 & 86 & 67 & 25 & 15 & 8 & 601 \\
\hline 2009 & 68 & 33 & 73 & -38 & -15 & -45 & -75 & -76 & -44 & 81 & 74 & 138 & 174 \\
\hline 2010 & 49 & 80 & -26 & 55 & 20 & -93 & -104 & -19 & 43 & 52 & 89 & 42 & 188 \\
\hline 2011 & 49 & 64 & -12 & 28 & -41 & -51 & -59 & -45 & 4 & 30 & 27 & 29 & 22 \\
\hline 2012 & 9 & 14 & 40 & 51 & 97 & 80 & 98 & 96 & 53 & 28 & 11 & 7 & 584 \\
\hline 2013 & 14 & 45 & 10 & 26 & 42 & -44 & -31 & -65 & -6 & 19 & 72 & 151 & 233 \\
\hline 2014 & 55 & 21 & 80 & -19 & 17 & -10 & -56 & -12 & 37 & 125 & 51 & 25 & 315 \\
\hline 2015 & 14 & 41 & 43 & -48 & -28 & -26 & -41 & -72 & -21 & 45 & 133 & 59 & 98 \\
\hline 2016 & 9 & 18 & 33 & 62 & 91 & 90 & 100 & 86 & 67 & 25 & 15 & 8 & 601 \\
\hline 2017 & 48 & 3 & -12 & 49 & -27 & -40 & -10 & -52 & 5 & 17 & 21 & 77 & 77 \\
\hline 2018 & 85 & 7 & 17 & -13 & -91 & -83 & -135 & -18 & -4 & -13 & 12 & 99 & -136 \\
\hline 2019 & 60 & 33 & 54 & -47 & -25 & -76 & -77 & -11 & 12 & 67 & 79 & 64 & 134 \\
\hline Gem. & 37 & 32 & 32 & 18 & 14 & -11 & -20 & -7 & 23 & 40 & 60 & 52 & 269 \\
\hline
\end{tabular}




\section{Stikstoflevering bodem}

Voor de stikstoflevering van de bodem (NLV) is voor de vergelijkbaarheid de stikstofhoeveelheid gelijk gehouden en niet gevarieerd voor de drie droogtevarianten en de twee bodemtypen. De hoeveelheid bedroeg $140 \mathrm{~kg}^{-1}$.ha-1, echter de stikstoflevering neemt af bij droogtestress (zie H.7 Discussie). 


\section{$3 \quad$ Methodiek}

\subsection{Waterpas}

Waterpas (De Vos et al., 2006) betreft een modelkoppeling van het BedrijfsBegrotingsProgramma (BBPR; Mandersloot et al., 1991 en Schils et al., 2007) en het hydrologische model SWAP (Kroes et al., 2017) om de interactie tussen de vochttoestand van de bovengrond en grasgroei te kunnen simuleren. SWAP geeft op basis van bodem- en hydrologische kenmerken in combinatie met de weergegevens input aan de grasgroeien graslandgebruiksmodule van BBPR. SWAP bepaalt op dagbasis of groeireductie optreedt (droogtestress of zuurstofstress) en geeft de draagkracht van de individuele bedrijfspercelen weer. BBPR berekent de dagelijkse grasgroei op basis van de stikstofgift en eventuele droogte of zuurstofstress aangeleverd vanuit SWAP. Daarnaast bepaalt de graslandgebruiksmodule of een perceel gebruikt kan en mag worden. In principe wordt de beweiding zo gepland dat de weidende diergroepen (melkkoeien, pinken of kalveren) gedurende het gehele groeiseizoen (of net zolang als de gebruiker aan het programma heeft opgegeven) dagelijks (beperkt) kunnen weiden. Al het gras dat niet nodig is voor het rondzetten van de beweiding wordt gemaaid voor voederwinning (graskuil). Wanneer bij vernatting de draagkracht onvoldoende is om te berijden, worden mest- en maaiactiviteiten uitgesteld tot het perceel weer een draagkracht heeft boven de drempelwaarde. Beweiden vindt wel plaats bij een lagere draagkracht dan de drempelwaarden, maar dan wordt op basis van de door SWAP berekende draagkracht schade ingerekend. Wanneer de schade echt te groot wordt (drempelwaarde draagkracht: 0,25 MPa) worden de weidende dieren opgestald en op stal bijgevoerd met geconserveerd ruwvoer. Indien niet alle percelen de zelfde draagkracht hebben, omdat de ontwatering niet overal gelijk is, zal het model zo lang mogelijk proberen te weiden op percelen met voldoende draagkracht. Deze bepalingen zijn van belang voor studies waarin vernatting een grote rol speelt. In de studie die in het voorliggende rapport staat beschreven was dit echter niet aan de orde en lag de focus op droogte.

Het model berekent integraal de effecten van de hydrologische toestand in bedrijfsverband. Uitgangspunt is een vaste (fixed) melkproductie, waardoor bij een tekort aan voer (kwantiteit en kwaliteit) extra voer dan wel extra kwaliteit (krachtvoer) zal worden aangekocht, om de vastgestelde productie in elk geval te kunnen halen en daarmee de plannen goed vergelijkbaar te laten zijn. Door deze gekozen aanpak wordt alleen gekeken naar het effect op de voedervoorziening en raakt dit effect niet verstrengeld met (melk)productie aspecten.

\section{$3.2 \quad$ BBPR}

BBPR bestaat uit de modules VoedervoorzieningsWijzer (VVW), Economie, Milieu en een module voor het berekenen van het saldo en een bedrijfsbegroting (Figuur 3.1). VVW (Werkgroep Normen voor de Voedervoorziening, 1991; Van der Kamp et al., 2003) simuleert aan de hand van de melkveestapel en de grasgroei het graslandgebruik. Voor het berekenen van grasgroei is gebruik gemaakt van het model GRAS2007 (Holshof en van den Pol, 2014). Het grasareaal binnen een bedrijf is opgesplitst in een aantal percelen voor melkvee en een aantal percelen voor jongvee (pinken en kalveren). De simulatie van het graslandgebruik betreft de beslissing om te weiden of te maaien en in het geval van weiden de beweidingsduur per perceel. Het graslandgebruik interacteert met de voeropname van melkvee en jongvee, wat respectievelijk wordt gesimuleerd met het Koemodel (Zom et al., 2002) en het jongveemodel. De voedervoorzieningswijzer berekent dus de voedervoorziening op het bedrijf dat van eigen land komt (vers gras, graskuil en maïs, eventueel ander veevoedergewassen als triticale, GPS, MKS of CCM) en geeft aan hoe eventuele tekorten moeten worden aangevuld. Strategische managementkeuzes in graslandgebruik, voeding en $\mathrm{N}$ bemesting en milieu/ weerseffecten (droogte, natschade) worden op deze wijze meegenomen en bepalen de 'eigen' voervoorraad en daarmee de zelfvoorzieningsgraad van ruwvoer. Op basis van de voedervoorziening worden vervolgens de opbrengsten, kosten en belangrijke milieueffecten berekend. Op 
basis van de resultaten van de modules VVW, Economie en Milieu worden saldo en bedrijfsbegroting berekend.

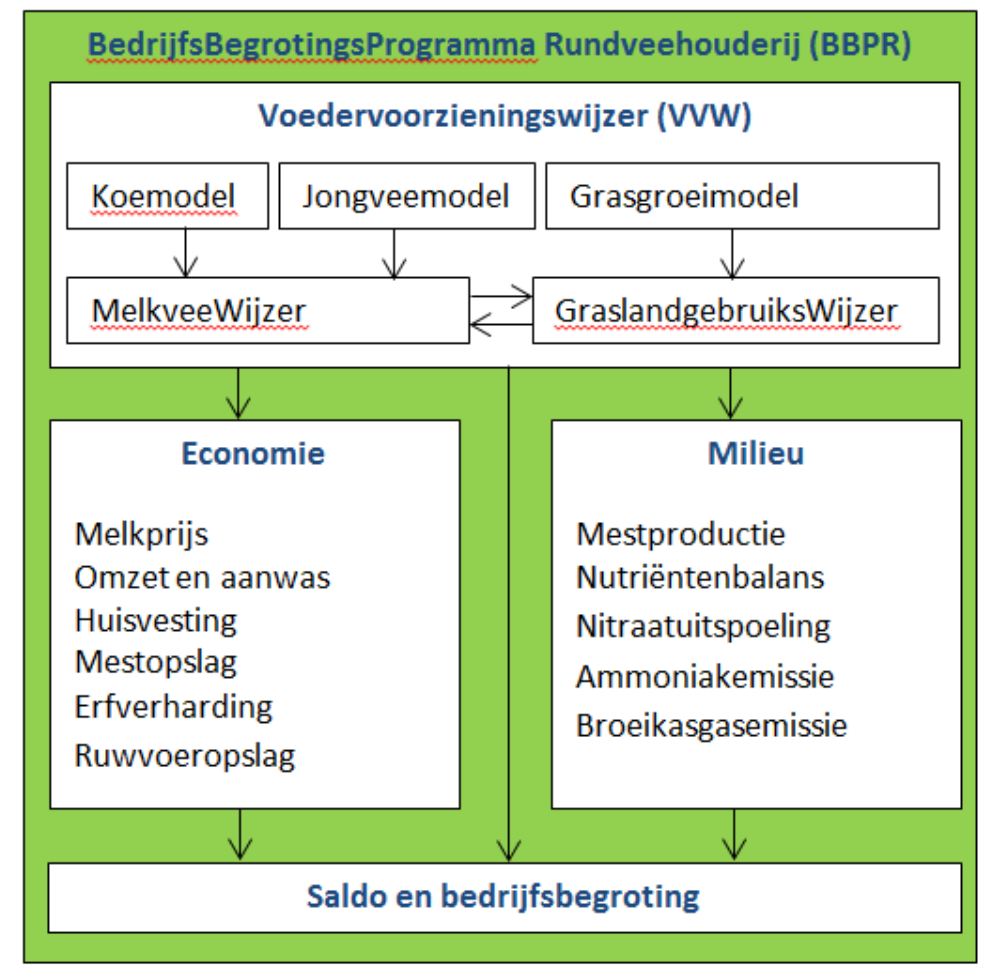

Figuur 3.1 BedrijfsBegrotingsProgramma Rundveehouderij (BBPR) en de modules en modellen die het vertegenwoordigt met schematisch weergegeven de onderlinge uitwisseling van data.

Door rekening te houden met interacties tussen de beschikbaarheid van stikstof als meststof, de grasproductie, de grasopname, de melkproductie, de mestproductie en het graslandgebruik hebben berekeningen op bedrijfsniveau voor de melkveehouderij een grote meerwaarde.

Voor het berekenen van de schadepercentages in Waterpas wordt gebruik gemaakt van de integratie van hydrologie en gewasgroei op basis van SWAP-GRAS2007. SWAP berekent per tijdstap drukhoogtes, grondwaterstanden en eventueel schijngrondwaterstanden waaruit per dag indirecte schade kan worden bepaald of om hydrologische karakteristieken te bepalen (zoals GXG) waarmee indirecte schades zijn gerelateerd. Per bedrijfstype worden $x$ percelen gedefinieerd met elk een eigen hydrologie en een groot aantal bedrijfskenmerken die bepalen hoe er beweid en/of gemaaid gaat worden en hoe drogestofopbrengsten en bijvoedering worden omgezet in melkproductie en bedrijfsresultaat.

Per perceel wordt per dag bekeken of het 'aan de beurt is' om beweid of gemaaid te worden en of dit mogelijk is, op basis van de drukhoogte op 12,5 cm -mv. Via een opzoektabel wordt een indringingsweerstand bepaald en of hierbij niet beweid of bereden kan worden en op basis daarvan worden vertrappings- of berijdingsverliezen bepaald. Met het BedrijfsBegrotingsProgramma Rundvee (BBPR) kunnen landbouwkundige, milieukundige en bedrijfseconomische kengetallen worden berekend, waarmee de fysieke effecten worden omgezet in verandering in euro's per ha. Voor wat betreft de bedrijfseconomische kengetallen is uitgegaan van de meest actuele prijzen en tarieven uit de KWIN-veehouderij (2019-2020).

\subsection{SWAP}

Het hydrologische model SWAP simuleert transport van water, opgeloste stoffen en warmte in de onverzadigde zone in interactie met vegetatieontwikkeling (Kroes et al., 2017). SWAP is ontwikkeld door Wageningen Universiteit en Alterra. De eerste versie van het SWAP model werd, voor toepassingen op veldschaal, reeds in 1978 ontwikkeld (Feddes et al., 1978) en sindsdien is het model veelvuldig toegepast en 
zijn diverse verbeteringen aangebracht. SWAP wordt gezien als het standaardmodel voor het bepalen van de actuele verdamping als functie van meteorologische gegevens gecombineerd met gewas en bodemgegevens (Feddes en Raats, 2004).

In SWAP zijn concepten toegevoegd om rekening te houden met macroporeuze stroming en waterafstotendheid. Om bladfotosynthese en gewasgroei te simuleren is de generieke gewasgroeimodule WOFOST ingebouwd. De modules bodemvocht, warmte en opgeloste stof wisselen bij elke stap statusinformatie uit om rekening te houden met allerlei interacties. Gewasgroei wordt dagelijks beïnvloed door de actuele bodemvochtigheid en het zoutgehalte. In verticale richting reikt het modeldomein van SWAP van een vlak net boven de bladmassa van een gewas tot een vlak in het ondiepe grondwater (zie Figuur 3.2).

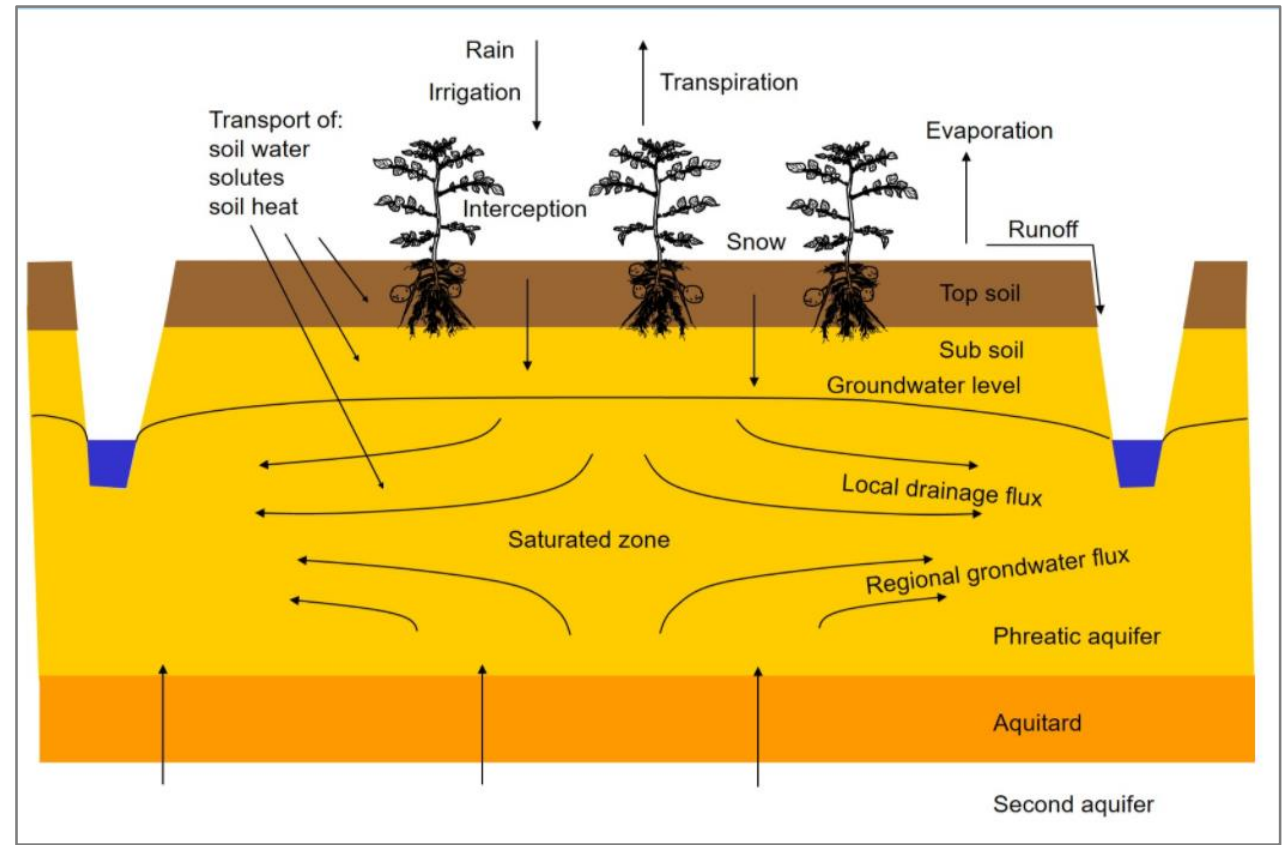

Figuur 3.2 Schematische weergave van het modeldomein van SWAP (Kroes et al., 2017), een vlak net boven de bladmassa van een gewas tot een vlak in het ondiepe grondwater, voor het simuleren van transport van water, opgeloste stoffen en warmte in de onverzadigde zone in interactie met vegetatieontwikkeling.

In de aangegeven zone zijn de transportprocessen overwegend verticaal, daarom is SWAP een eendimensionaal, verticaal gericht model. De stroming onder het grondwaterpeil mag laterale drainagefluxen omvatten, mits deze fluxen kunnen worden voorgeschreven met analytische drainageformules. In horizontale richting is de perceelschaal de belangrijkste focus van SWAP. Op deze schaal kunnen de meeste transportprocessen op een deterministische manier worden beschreven, aangezien een perceel in het algemeen kan worden weergegeven door één microklimaat, één vegetatietype, één bodemtype en één afwateringsconditie. Ook zijn teeltmaatregelen veelal op perceelschaal van toepassing. Op basis van geografische informatiesystemen is voor bredere beleidsstudies opschaling van perceel- naar regionale schaal mogelijk.

SWAP maakt gebruik van de Richards-vergelijking inclusief wateropname van plantenwortels om de beweging van bodemvocht in variabel verzadigde bodems te simuleren. De wateropname van wortels is beschreven door het opnemen van de zogenaamde 'sink-term' in de Richards' vergelijking voor stroming van water in de onverzadigde zone. De actuele wateropname $S$ van planten wordt berekend door de maximale wateropname $S_{\max }$ te vermenigvuldigen met stressfactoren voor droogte-, zuurstof- en zoutstress, respectievelijk $a_{d r o o g t e}, a_{z u u r s t o f}$ en $a_{\text {zout: }}$ :

$$
S(z)=\alpha_{\text {droogte }} \alpha_{\text {zuurstof }} \alpha_{\text {zout }} S_{\text {max }}(z)
$$


$S_{\max }$ is de maximale wateropname door planten en wordt bepaald door de potentiële transpiratie te verdelen over verschillende diepten $z$ aan de hand van het verloop van de worteldichtheid met de diepte. Smax is geïntegreerd over de worteldiepte en dus weer gelijk aan de potentiële transpiratie. Integratie van $S(z)$ over de wortelzone levert de actuele transpiratie.

De reductie in actuele transpiratie als gevolg van beschikbaar vocht in de bodem wordt weergegeven door de zogenaamde wortelonttrekkingsfunctie volgens Feddes et al. (1978) en is schematisch weergegeven in Figuur 3.3. Zowel te droge als te natte omstandigheden leiden tot een niet optimale transpiratie omdat plantenwortels dan onvoldoende water kunnen opnemen. SWAP beschrijft elk van de factoren die deel uitmaken van de verdamping: evaporatie van de bodem, transpiratie van het gewas en interceptieverdamping. In SWAP-WOFOST wordt de Feddes functie alleen gebruikt voor droogtestress. Voor de natte omstandigheden wordt de zuurstofstressmodule volgens Bartholomeus et al. (2012) gebruikt.

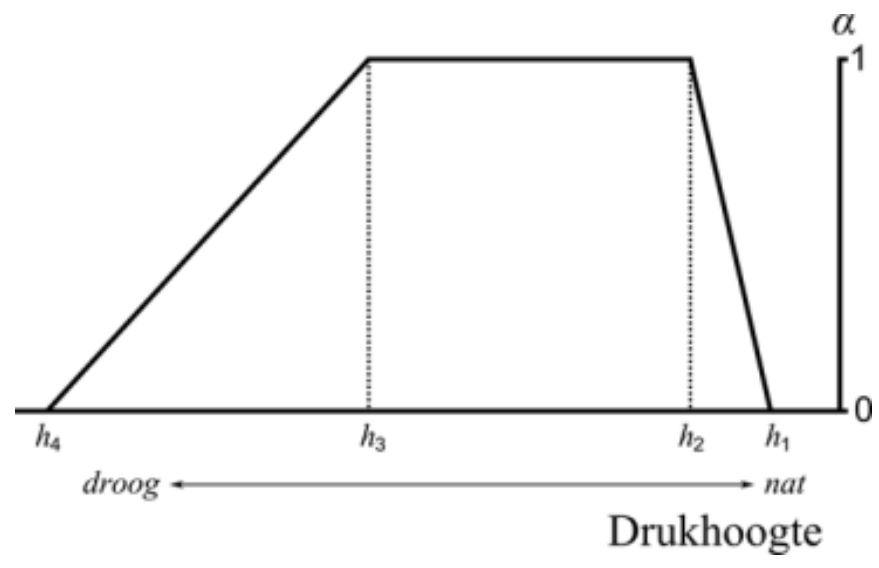

Figuur 3.3 Relatieve wortelopname a (relatief ten opzichte van potentiële opname) als functie van de drukhoogte $h$ volgens Feddes et al. (1978), zoals gebruikt voor de berekening van droogte- en natschade in SWAP. De wateropname door wortels neemt lineair af van $h_{3}$ tot $h_{4}$ door droogtestress. Tussen h2 en h3 is de wateropname optimaal $(a=1)$. Volgens deze functie neemt de wateropname af door zuurstofstress tussen de kritische grenswaarden $h_{2}$ en $h_{1}$.

In Waterpas wordt SWAP niet in combinatie met WOFOST gebruikt, maar met GRAS2007 om grasgroei te simuleren. De belangrijkste reden is dat GRAS2007 zonder kalibratie realistische opbrengsten schat (stochastisch model), het naast biomassa voederwaardekenmerken berekent (nodig voor het berekenen van o.a. melkproductie en economische waarde) en kan omgaan met stikstof als groeiparameter. De beschikbaarheid van stikstof uit bodem en meststoffen is afhankelijk van het bedrijfsmanagement en het graslandgebruik. In waterpas wordt een praktische interpretatie van de reductiefunctie van Feddes et al. (1978) gebruikt om zowel de groeireductie door droogte als vernatting te berekenen. Zie voor een nadere toelichting paragraaf 3.4 .

\subsection{Grasgroei}

Bron: Hoving et al. (2019).

Voor een modelmatige voorspelling van de grasgroei is in het onderzoek gebruik gemaakt van GRAS2007, een stochastisch model van Wageningen Livestock Research dat gebaseerd is op alle groeiverloopproeven die de laatste decennia zijn uitgevoerd. Het model geeft een goede voorspelling van de grasgroei op goede cultuurgraslanden (80-100\% Engels raaigras), maar ook voor graslanden met een meer gevarieerd grassenbestand (Holshof en van den Pol, 2014) die lager gewaardeerd worden. In GRAS2007 wordt gebruik gemaakt van een stikstofbalans, waarbij de stikstofopbrengst geschat wordt op basis van stikstofleverend vermogen van de bodem (NLV), uit stikstof gegeven met kunstmest en dierlijke mest en uit onbenutte stikstof uit een vorige snede. De stikstofopbrengst vanuit de bodem wordt als stikstofjaaropbrengst voor drie grondsoorttypen geschat (zand, klei en veen) en volgens een sigmoïde curve verdeeld over het groeiseizoen (stikstoflevering per dag). De (geschatte) stikstoflevering kan ook als input worden opgegeven. De stikstof 
uit toegediende (kunst)mest wordt met een vertragingsfactor (tijd gift en tijd opname) opgenomen in de plant. Over de totale beschikbare stikstof wordt een efficiëntie geschat. Vanuit een stikstofopbrengst wordt vervolgens de droge stofopbrengst geschat door middel van een aantal factoren (snedenummer, dag in het seizoen, stikstofgift en groeiduur). Vervolgens wordt de grasopbrengst per dag gecorrigeerd voor eventuele stress door droogte of vernatting, op basis van de berekende bodemvochtsituatie in het midden van de wortelzone $(12,5 \mathrm{~cm}-\mathrm{mv})$ met SWAP.

Zowel te droge als te natte omstandigheden leiden tot een suboptimale transpiratie omdat plantenwortels dan onvoldoende water kunnen opnemen. Voor het berekenen van reducties in de wateropname door te droge (watertekort) en te natte (zuurstoftekort) omstandigheden heeft Feddes et al. (1978) een wortelonttrekkingsfunctie ontwikkeld (zie paragraaf 3.3 en Figuur 3.3). Bij optimale bodemvochtcondities zijn de plantenwortels in staat te voldoen aan de potentiële opname. Bij te droge omstandigheden wordt de waterflux naar de wortels kleiner dan de potentiële opname. Deze afname wordt uitgedrukt in een reductiecoëfficiënt die varieert van 0.0 (geen opname) tot 1.0 (potentiële opname).

Voor het bepalen van de actuele gewasverdamping in GRAS2007 is gebruik gemaakt van een afgeleide van de Feddes reductiefunctie. De verdampingsreductie bij een relatief natte en een relatief droge vochttoestand van de bodem (wortelzone) worden volgens twee verschillende functies beschreven. Daarbij is voor het droge traject onderscheid gemaakt in een relatief hoge en in een relatief lage verdampingsvraag. Op basis een beregeningsexperiment op grasland (Hoving en van Riel, 2003) en praktijkervaring zijn niet lineaire functies opgesteld, omdat bij lineaire functies de verdamping te snel reduceert in vergelijking tot de praktijk. Een belangrijk ijkpunt hierbij is dat bij een zuigspanning in de wortelzone ter grootte van $\mathrm{pF}=2,7$ (drukhoogte $-500 \mathrm{~cm}$ ) de actuele verdamping gemiddeld $50 \%$ van de potentiële verdamping bedraagt. In Figuur 3.4 staat de uitwerking van de Feddes functie voor GRAS2007 (Hoving et al., 2019).

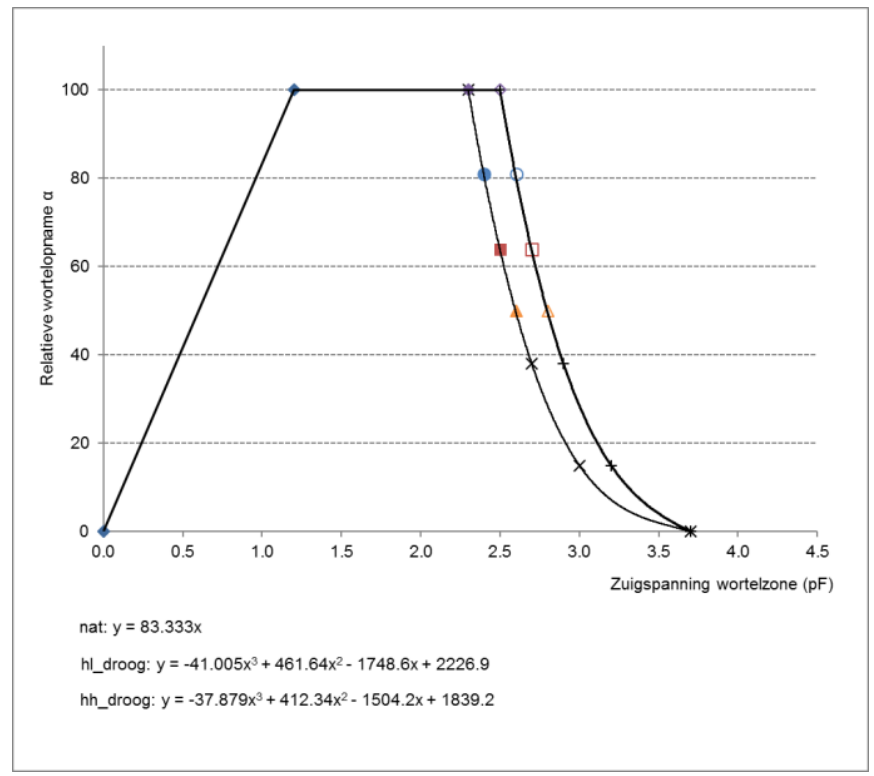

Figuur 3.4 Relatieve wortelopname a (relatief ten opzichte van potentiële opname) als functie van de zuigspanning pF volgens Feddes et al. (1978), toegepast in GRAS2007 om de transpiratiereductie te berekenen, met een functie voor het natte traject ('Nat') en functies voor een lage verdampingsvraag $(h /)$ en een hoge verdampingsvraag $(h h)$ voor gras. Bij $(a=100)$ is de wateropname optimaal.

Onder suboptimale vochtvoorziening in de wortelzone zal de potentiële transpiratie ( $\left.T_{\text {pot }}\right)$ afnemen tot de actuele transpiratie ( $\left.T_{\text {act}}\right)$, waardoor de gewasopbrengst lager wordt dan potentieel haalbaar is. De groeireductie door nat- of droogteschade wordt in GRAS2007 berekend door de groei te corrigeren met een transpiratiefactor. De relatieve gewasopbrengst $\left(Y_{\mathrm{act}} / Y_{\mathrm{pot}}\right)$ wordt gelijk gesteld aan relatieve transpiratie ( $\left.T_{\text {act }} / T_{\text {pot }}\right)$ volgens Vergelijking 2 op basis van Doorenbos and Kassam (1979).

$$
\left(1-\frac{Y_{a c t}}{Y_{p o t}}\right)=K_{Y}\left(1-\frac{T_{a c t}}{T_{p o t}}\right)
$$


Waarbij:

Ypot : Potentiële gewasopbrengst

Yact : Actuele gewasopbrengst

Ky : : gewasresponsfactor (= 1 voor gras)

Tpot : Potentiële transpiratie

Tact : Actuele transpiratie

Voor gewasverdamping wordt gebruik gemaakt van de formule van Makkink (KNMI-data). De potentiële verdamping wordt gerelateerd aan de potentiële verdamping van een referentiegewas via een gewasfactor (Vergelijking 2):

$$
E T_{\mathrm{po}}=K_{c} E T_{\text {ref }}
$$

waarin $E T_{\text {po }}(\mathrm{mm} / \mathrm{d})$ gelijk is aan de potentiële verdamping van een willekeurig gewas, $K_{\mathrm{c}}(-)$ is de gewasfactor en $E T_{\text {ref }}(\mathrm{mm} / \mathrm{d})$ is de potentiële verdamping van een referentiegewas. Het referentiegewas is gras en de $K_{\mathrm{c}}=1$.

\subsection{GLG en GHG}

De grondwaterstanden in de zomer zijn een belangrijk gegeven voor het bepalen van het effect van vernattingsmaatregelen. Voor de interpretatie van de grondwaterstanden is de hydrologische parameters Gemiddeld Laagste Grondwaterstand (GLG) berekend. De GLG is berekend door eerst per jaar de LG3 te berekenen en deze waarden vervolgens te middelen over de reeks van vijf jaren. Conform protocol (Cate et al., 1995) is de LG3 berekend door per jaar respectievelijk in de periode van 1 april tot 1 november de drie laagste grondwaterstanden gemeten op $14^{\mathrm{e}}$ en $28^{\mathrm{e}}$ van de maand te middelen. Het protocol schrijft echter ook voor dat de GLG over tenminste een reeks van tenminste acht weerjaren berekend moet worden. Met de kortere proefperiode van vijf jaar kon hier niet aan voldaan worden.

\subsection{Verandering grasproductie na herinzaai}

Herinzaaien van grasland kost opbrengst door het scheuren van de oude zode maar brengt vervolgens extra gras op doordat verbetering van het grasbestand en de dichtheid van de zode. De effecten zijn afhankelijk van de productiviteit van de oude zode en het percentage herinzaai. Om de netto productieverandering te berekenen is gebruik gemaakt van het model HerinzaaiWijzer (Hoving, 2006) dat door Wageningen Livestock Research is ontwikkeld en als applicatie op internet beschikbaar is (http://webapplicaties.wur.nl/software/herinzaaiwijzer). Met de internetapplicatie kan berekend worden of het lonend is om een graszode te vernieuwen. Deze applicatie berekent het verschil tussen de kosten van graslandverbetering en de te verwachten meeropbrengst van grasland in de eerste tien jaren na herinzaai. Naast de kosten van herinzaai is er sprake van verlies aan stikstof en koolstof door afbraak van organische stof in de bodem en van de oude zode. Dat leidt tot een lagere meeropbrengst en draagt bij aan de broeikasgasemissie. De financiële herinzaaikosten, de actuele botanische samenstelling, het tijdstip van herinzaai, de groeiomstandigheden en het verlies aan organische stof bepalen samen of herinzaai financieel aantrekkelijk is of niet. De groeiomstandigheden worden gekarakteriseerd door grondsoort, vochtvoorziening (grondwatertap) en de stikstofjaargift. Het verlies aan organische stof is afhankelijk van het tijdstip van scheuren en het onderbreken van het blijvend grasland met een of meerdere jaren snijmaïs

In het onderstaande staat de modelbenadering van de grasproductie na herinzaai beschreven volgens Hoving (2006).

In de HerinzaaiWijzer is een exponentiële afname van de bruto grasproductie verondersteld in de tijd tussen de potentiële productie en de productie op lange termijn. Het productieverloop op lange termijn is uitsluitend afhankelijk gesteld van de vochtvoorziening, uitgedrukt in grondwatertrap. De productieafname op lange termijn wordt gecorrigeerd voor een afname op korte termijn, jaar 1 tot en met 5, uitgaande van de 
opbrengstpiek direct na scheuren als startpunt van de curve. Deze correctie is afhankelijk gesteld van zowel grondsoort als grondwatertrap. De formule voor de bruto grasproductie is als volgt:

$y(t)=$ basisproductie + productiepiek direct na herinzaai

$y(t)=\left(b+(a-b) * c^{t}\right) *\left(1+\left(d * e * f^{t}\right)\right)$

De volgende factoren zijn in de formule opgenomen:

a Potentiële productie

b Productie op lange termijn

c Degeneratiefactor lange termijn

d Productiepiek na herinzaai

e Correctiefactor voor productiepiek na herinzaai

$\mathrm{f}$ Degeneratiefactor productiepiek korte termijn

$t \quad$ Tijd in jaren

y Bruto drogestof opbrengst

Het deel $\left(b+(a-b) * c^{t}\right)$ in de formule beschrijft het productieverloop op de lange termijn, de 'basis' productie. Het deel $\left(1+\left(d^{*} e^{*} f^{t}\right)\right)$ beschrijft de productiepiek direct na herinzaai. De correctiefactor (e) is bedoeld als rekenkundige correctie om gemiddeld in het eerste jaar na herinzaai op een productiepiek uit te komen van $10 \%$, in plaats van alleen bij de start van het eerste jaar. De correctiefactor is afhankelijk van het potentiële productieniveau en de mate van degeneratie en wordt zodoende door het programma berekend.

Om een koppeling mogelijk te maken tussen het actuele grasbestand en de productie is aan het productieverloop een aandeel goede grassen inclusief klaver verbonden. Aangenomen is dat de degeneratie kan worden toegeschreven aan een afname van het aandeel goede grassen en de mate waarin dit gebeurt afhankelijk is van de ontwateringtoestand van de bodem (grondwatertrap), als equivalent voor de natuurlijke groeiomstandigheden. Indirect beïnvloeden de groeiomstandigheden het graslandgebruik, zoals het aandeel weiden en maaien, de snedezwaarte en de hoeveelheid beweiding- en vertrappingverliezen, waardoor het aandeel goede grassen gemakkelijker of minder gemakkelijk in de praktijk te handhaven is. Na herinzaai wordt het aandeel goede grassen inclusief klaver optimaal verondersteld en na verloop van tijd daalt dit aandeel, waardoor de productiviteit van de zode vermindert. Het aandeel goede grassen is eveneens ingeschat op basis van praktijkkennis, mede ondersteund door gegevens uit het proefschrift van Korevaar (1987). Gekozen is voor een aandeel goede grassen, omdat dit voor de gebruiker gemakkelijker is te schatten dan het aandeel van afzonderlijke grassoorten en onkruiden. Onder goede grassen en gewenste soorten in grasland verstaan we de soorten Engels raaigras, Timothee, Beemdlangbloem en witte klaver (Sikkema, 1997).

De grootte van de factoren en het percentage goede grassen inclusief klaver zijn afhankelijk gesteld van de grondsoort/Gt combinatie en staan in Tabel 6. 
Tabel 6 Modelfactoren en het percentage goede grassen inclusief klaver afhankelijk van de combinatie grondsoort en grondwatertrap. De productie op lange termijn en de extra productie in het eerste jaar betreft percentuele correcties van de potentiële productie.

\begin{tabular}{|c|c|c|c|c|c|c|c|c|c|}
\hline Gt & II & II* & III & III* & $\mathbf{v}$ & $\mathbf{V *}$ & IV & VI & VII \\
\hline \multicolumn{10}{|l|}{ Zand / Loss } \\
\hline Productie lange termijn (\%) & 65 & 70 & 65 & 70 & 65 & 70 & 80 & 75 & 70 \\
\hline Extra productie jaar $1(\%)$ & 10 & 10 & 10 & 10 & 10 & 10 & 10 & 10 & 10 \\
\hline Degeneratie jaar 1-5 (\%/jaar) & 40 & 40 & 40 & 40 & 40 & 40 & 40 & 40 & 40 \\
\hline Degeneratie jaar 5-20 (\%/jaar) & 15 & 7,5 & 15 & 7,5 & 15 & 7,5 & 3 & 5 & 7,5 \\
\hline Goede grassen + klaver lange termijn (\%) & 30 & 35 & 30 & 35 & 30 & 35 & 45 & 40 & 35 \\
\hline \multicolumn{10}{|l|}{ Klei / Zavel } \\
\hline Productie lange termijn (\%) & 65 & 70 & 65 & 70 & 65 & 70 & 80 & 75 & 70 \\
\hline Extra productie jaar $1(\%)$ & 10 & 10 & 10 & 10 & 10 & 10 & 10 & 10 & 10 \\
\hline Degeneratie jaar 1-5 (\%/jaar) & 30 & 30 & 30 & 30 & 30 & 30 & 30 & 30 & 30 \\
\hline Degeneratie jaar 5-20 (\%/jaar) & 15 & 7,5 & 15 & 7,5 & 15 & 7,5 & 3 & 5 & 7,5 \\
\hline Goede grassen + klaver lange termijn (\%) & 30 & 35 & 30 & 35 & 30 & 35 & 45 & 40 & 35 \\
\hline \multicolumn{10}{|l|}{ Veen $^{1}$} \\
\hline Productie lange termijn (\%) & 65 & 70 & 65 & 70 & & & & & \\
\hline Extra productie jaar $1(\%)$ & 15 & 15 & 15 & 15 & & & & & \\
\hline Degeneratie jaar 1-5 (\%/jaar) & 50 & 50 & 50 & 50 & & & & & \\
\hline Degeneratie jaar 5-20 (\%/jaar) & 15 & 7,5 & 15 & 7,5 & & & & & \\
\hline Goede grassen + klaver lange termijn $(\%)$ & 30 & 35 & 30 & 35 & & & & & \\
\hline
\end{tabular}

${ }^{1}$ Voor veengrond zijn uitsluitend factoren opgenomen voor Gt II, II*, III en III*. De overige Gt klassen komen niet of nauwelijks voor op een pure veengrond

In Figuur 3.5 is het productieverloop op de lange termijn (basis drogestofproductie) en de totale drogestofproductie weergegeven voor een zandgrond met een dun dek, Gt VI. De productiepiek direct na herinzaai is van relatief korte duur, in dit voorbeeld ongeveer 2 jaar. In de grafiek is niet gecorrigeerd voor het directe productieverlies in het jaar van herinzaai.

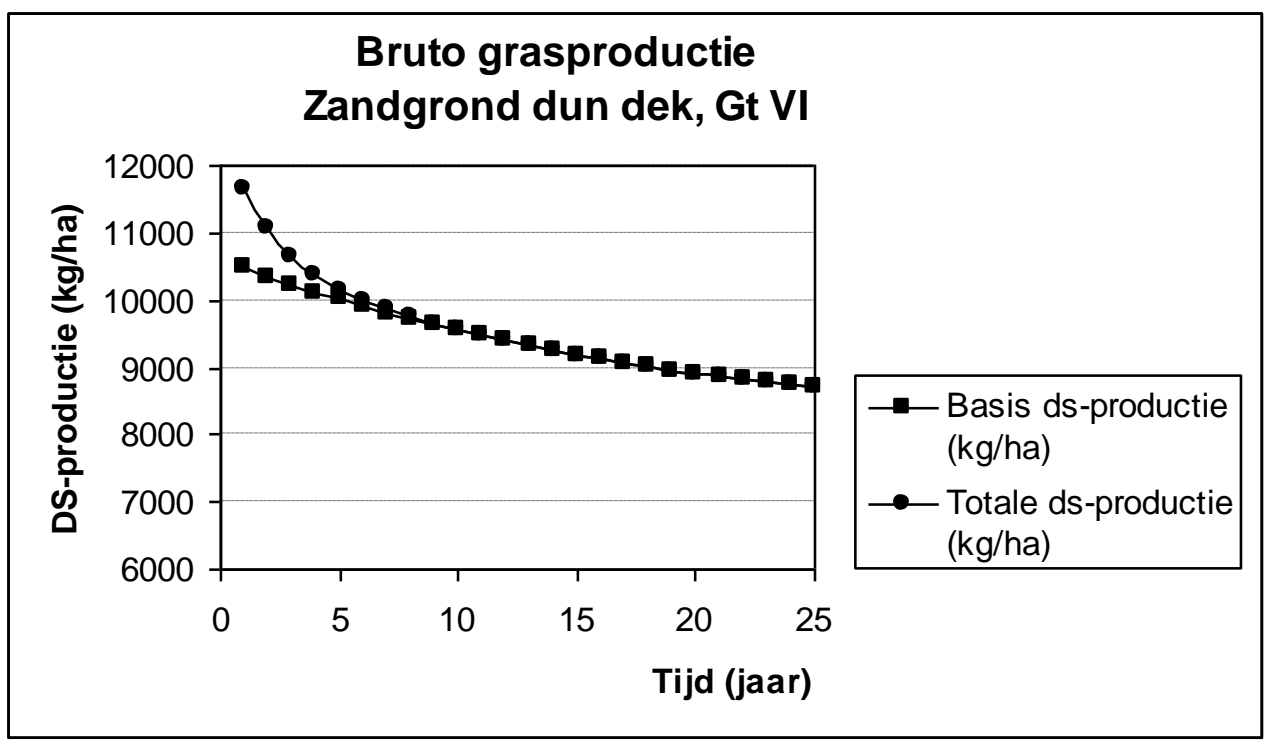

Figuur 3.5 Basis drogestofproductie en de totale drogestofproductie, inclusief de kortdurende productiepiek direct na herinzaai.

In het jaar van herinzaai treedt een productieverlies op als gevolg van vernietiging van de oude zode en vorming van een nieuwe zode. In het model wordt de bruto productie voor dit verlies gecorrigeerd. Bij scheuren in het voorjaar wordt de eerste snede gemist en is het verlies geschat op $25 \%$. Woldring (1975) vond bij herinzaai in het voorjaar (éénjarige proef) een drogestofverlies van $18 \%$ bij opbrengst van 9,1 
ton/ha. Hoogerkamp (1970) noemt een verlies aan drogestofproductie bij voorjaarsinzaai van $25-50 \%$. Bij scheuren in de nazomer mist men een najaarsnede en wordt het verlies geschat op 12,5\%. Met gegevens van Luten et al. (1976) is het verlies geschat op 17-20\% bij herinzaai van goed grasland half augustus. De Vliegher et al. (2001) vonden bij herinzaai van goed grasland in het najaar verliezen van 8-12\%. In dit onderzoek werd het nieuwe gras relatief laat ingezaaid (half september-begin oktober), dat weliswaar het drogestofverlies in het jaar van inzaai beperkte, maar negatieve consequenties leek te hebben voor de grasopbrengst in de volgende jaren. In een veldexperiment uitgevoerd door Hoving \& Velthof (2005) bleek dat bij herinzaai in het najaar voor 15 september het productieverlies ongeveer even groot is als bij herinzaai in het voorjaar, namelijk ongeveer $25 \%$ van de jaaropbrengst. In de Herinzaaiwijzer is uitgegaan van een direct productieverlies ter grootte van $25 \%$ van de jaaropbrengst van de oude zode.

Ook is rekening gehouden met het verlies van stikstof als het gevolg van het vrijkomen van stikstof door mineralisatie van de oude zode. In Tabel 7 staan de resultaten van Hoving en Velthof (2005), waarbij de vermindering van $\mathrm{N}$-levering afhankelijk was van het tijdstip van scheuren en het $\mathrm{N}$-bemestingsniveau. Bij $300 \mathrm{~kg} \mathrm{~N}$ per ha per jaar bleef de vermindering van N-levering bij scheuren in het voorjaar beperkt tot ongeveer $30 \mathrm{~kg}$ per ha, maar bij scheuren in het najaar was de vermindering van N-levering $180 \mathrm{~kg} \mathrm{~N}$ per ha. De hoeveelheid stikstof die vrijkomt is niet per definitie een milieuverlies, maar betreft ook vastlegging in de nieuw te vormen zode. In de jaren na herinzaai moet dit verlies gecompenseerd worden óf door het accepteren van productieverlies bij gelijke bemesting óf door extra bemesting. In het programma is gekozen voor een productieverlies, dat berekend wordt door de verminderde $\mathrm{N}$-levering uit Tabel 7 te vermenigvuldigen met een marginaal stikstofeffect van $11 \mathrm{~kg}$ droge stof per kg stikstof (Vellinga, 1998).

Tabel $7 \quad$ Vermindering $N$-levering bodem na scheuren gemiddeld over de proefperiode in $\mathrm{kg}$ per ha ten opzichte van niet gescheurd grasland (Hoving en Velthof, 2005).

\begin{tabular}{|c|c|c|c|c|}
\hline \multirow[t]{2}{*}{ Scheurbehandelingen } & \multicolumn{4}{|c|}{ Stikstofbemesting (kg N.ha- ${ }^{-1}$ jaar $^{-1}$ ) } \\
\hline & $\mathbf{O} \mathbf{N}$ & $150 \mathrm{~N}$ & $300 \mathrm{~N}$ & $450 \mathrm{~N}$ \\
\hline Scheuren voorjaar & 18 & 23 & 29 & 34 \\
\hline Scheuren najaar & 159 & 163 & 180 & 209 \\
\hline Scheuren voorjaar - scheuren najaar & 141 & 140 & 151 & 174 \\
\hline
\end{tabular}

Voor het berekenen van de kosten voor herinzaai door extra droogte, zijn op basis van berekende herinzaaifrequenties (CGO-onderzoek) de gemiddelde opbrengsten van de droogtevarianten uit de modelberekeningen (zonder herinzaai) gecorrigeerd met het Herinzaaiwijzermodel voor het directe opbrengstverlies door scheuren, de productiepiek direct na herinzaai, het productieverloop in de jaren na herinzaai en het stikstofverlies.

De bruto grasproductie is gecorrigeerd voor voederwaarde en opname om tot een netto opbrengst te komen. Voor de voederwaarden wordt uitgegaan van het Tabellenboek Veevoeding (2002) van het Centraal Veevoederbureau (CVB). Voor de lange termijn is een voederwaarde verondersteld van $90 \%$ van de CVBwaarden. De voederwaarden zijn afhankelijk van de stikstofjaargift. Voor energie (VEM), darm verteerbaar eiwit (DVE) en ruw eiwit (RE) staat in Tabel 8 een overzicht. 
Tabel 8 Overzicht voederwaarden VEM, DVE en RE afhankelijk van de stikstofjaargift, gebaseerd op de normen volgens het Tabellenboek Veevoeding (2002)

\begin{tabular}{lccc}
\hline Voederwaarde & $\begin{array}{c}\text { N-gift } \\
\text { (kg N/ha/jaar) }\end{array}$ & $\begin{array}{c}\text { Potentieel } \\
\mathbf{( g / k g )}\end{array}$ & $\begin{array}{c}\text { Lange termijn } \\
\mathbf{( g / k g )}\end{array}$ \\
\hline VEM & 200 & 974 & 876,6 \\
\hline & 300 & 987 & 888,3 \\
\hline & 400 & 994 & 894,6 \\
\hline (Tabellenboek Veevoeding, 2002) & & 87,3 \\
\hline (90) van potentieel) & (Tabellenboek Veevoeding, 2002) \\
\hline & 200 & 97 & 90,45 \\
\hline 300 & 100,5 & 93,15 \\
\hline RE & 400 & 103,5 & 169,2 \\
\hline & & 185,4 \\
\hline & 200 & 188 & 202,5 \\
\hline
\end{tabular}




\section{$4 \quad$ Engels raaigras en droogtestress}

\subsection{Engels raai}

Engels raaigras (Lolium perenne L.) is het belangrijkste voedergras in Noordwest-Europa en Nieuw-Zeeland en in de binnenlanden van Japan, Australië, Zuid-Afrika en Zuid-Amerika (Wilkins and Humphreys, 2003). Gewaardeerde eigenschappen van Engels raaigras zijn de hoge potentiële productie, het behoud van productie onder beweidingsomstandigheden (Tallowin et al. 1995), de goede voederwaarde kenmerken, waaronder een hoog eiwitgehalte en een goede opname door melkvee. Tolerantie voor beweiding en klimatologische stress, persistentie (het standhouden van grassen in relatie tot weiden en maaien) en weerstand tegen ziekten en plagen kunnen een grote invloed hebben op de opbrengst, vooral in de tweede en volgende oogstjaren na inzaai (Wilkins and Humphreys, 2003).

\subsection{Droogte en persistentie}

\section{Temperatuur en vochttekort}

Van de abiotische stress heeft droogte waarschijnlijk de grootste invloed op de productiviteit, overleving en ontwikkeling van planten (Ciais et al. 2005). Overblijvende grassen gaan in reactie op vochttekort uitdroging voorkomen door of meer water op te nemen of verdamping te beperken (Volaire et al., 2009). Vochttekort zorgt voor een tragere groei ofwel een lagere bladproductie en bij langdurige droogte voor het afsterven van spruiten en uiteindelijk hele planten. Volgens Volaire (2009) vertonen grassen die niet in zomerrust gaan (Mediterrane soorten) bij voortschrijdende droogte een aantal opeenvolgende aanpassingen. Eerst worden de bladgroei en vervolgens de bladinitiatie verminderd en vervolgens gestopt, vervolgens nemen de gasuitwisseling en fotosynthese af en vordert de veroudering van de lamina (Blum, 1996; Ludlow et al., 1989). Wanneer de gasuitwisseling minimaal is, kunnen planten zo met lang overlevende organen (meristeemweefsels aan de basis van omsloten bladeren en wortels) hun functionele integriteit behouden om opnieuw te groeien wanneer het watertekort wordt opgeheven. De combinatie van tot uitdrukking gebrachte aanpassingen zal over het algemeen deel uitmaken van een van de twee hoofdstrategieën, ofwel om de uitdroging van meristemen te vertragen of te tolereren.

De Haan et al. (2019) geeft aan dat in het project Koeien \& Kansen de ervaring is dat blijvend grasland kwetsbaarder is voor extreme droogte dan tijdelijk of jong grasland. De grotere worteldiepte van jong gras speelt hierbij ook een belangrijke rol. De vochtbeschikbaarheid is hierdoor groter waardoor de verdampingsvraag lager is en droogtestress minder acuut optreedt.

Voor de meeste gebruikte grassoorten in Nederland, waaronder Engels raaigras, reduceert de groei bij hogere temperaturen door het verminderen van fotosynthese en treedt fysieke schade op bij extreem hoge temperaturen. In de praktijk wordt ervaren dat boven de $\mathbf{2 5}$ graden de groei stagneert, echter hier werd geen onderbouwing vanuit de literatuur voor gevonden.

\section{Grassoorten}

De meest extreem tolerante grassoorten overleven door in zomerrust te gaan om hoge temperaturen en vochttekort te overleven (Reed et al., 2001). Nichols et al. (2016) schrijft dat goed producerende grassoorten - zoals Engels raaigras, kropaar en rietzwenkgras - in gematigde klimaat zones met relatief veel regenval, zomerrust nodig hebben om te overleven onder droge omstandigheden. Woodward et al. (1992) heeft in Nieuw-Zeeland diverse grassoorten (waaronder ook Engels raaigras, Lp) meerdere jaren getest onder droge omstandigheden. De persistentie van Engels raaigras liep duidelijk terug na het derde jaar, waar andere soorten als bijvoorbeeld kropaar goed standhielden. Ook Westermeier et al. (2016) geeft aan dat Engels raaigras geen uitgesproken droogtetolerante grassoort is. 


\section{Ploïdi en rassen}

Aangezien Engels raaigras in diverse Europese klimaatzones groeit, mag binnen deze soort verschil in droogtetolerantie tussen rassen worden verwacht (Westermeier et al., 2016). In droge regio's is het behoud van opbrengst niet het belangrijkste doel, maar veel meer een goed herstel na een periode van watertekort. Rassen verschillen in herstellingsvermogen. Woodward et al. (2020) verwacht dat een extensiever gebruik en het veredelen van droogteresistente rassen niet direct succesvol is in het voorkomen van de lagere persistentie. Ook Rogers et al. (2015) heeft geen raseffect in persistentie na droogte aangetoond in proeven uitgevoerd in Zuid-Australië. Wel was de bezetting in de proeven na een periode met een watertekort duidelijk lager in vergelijking met de beregende proeven. Westermeier et al. (2015) daarentegen laat aan de hand van een proef met 200 rassen van Engels raaigras zien dat er grote verschillen in droogtetolerantie zijn. Waarbij tetraploïde rassen meer droogtetolerant waren dan diploïde rassen. Vroegheid (schietdatum) gaf geen verschillen te zien.

Tozer et al. (2017) geeft aan de hand van diverse studies aan dat diploïde en tetraploïde rassen verschillend reageren op stress doordat ze verschillen in morfologie en een aantal landbouwkundige eigenschappen.

Tetraploïde rassen hebben in het algemeen een lagere zodedichtheid en minder spruiten. Tetraploïde planten zijn beter in staat uitdroging en afsterven te voorkomen, maar door de lagere spruitdichtheid kunnen ze bij voortdurende droogte toch een opener zode krijgen en een daarmee lager herstellingsvermogen in vergelijking met diploïde planten. Onder beweiding kan het korter afgrazen van tetraploïde planten ook een rol spelen.

Deru et al. (2014) heeft van een aantal rassen - die verschilden in opbrengst en standvastigheid - de wortelmassa bepaald. De rassen verschilden inderdaad in wortelmassa, maar dit was niet te linken aan de opbrengst en standvastigheidscijfers. De resultaten laten wel zien dat het mogelijk moet zijn Engels raaigras rassen te selecteren die een hoge opbrengst kunnen combineren met een hoge wortelmassa.

\section{Persistentie en herstel}

Een hoge grasproductie, zoals van Engels raaigras, gaat veelal ten koste van de persistentie, omdat deze grassen meer reproductieve spruiten ontwikkelen dan gematigde grassen welke bovendien een lager gehalte aan opgeloste koolhydraten hebben (Takasaki et al., 1989). Vooral na maaien blijft relatief weinig groen blad achter waardoor de hergroei van blad volledig afhankelijk is van de mobilisatie van koolhydraat- en stikstofreserves in de stoppels (Ourry et al., 1989). Het afsterven van spruiten is de belangrijkste oorzaak van teruglopende persistentie (Woodward et al., 2020 en Tozer et al., 2017). Koolhydraatreserves spelen een belangrijke rol bij hergroei omdat ze de belangrijkste energiebron zijn voor de plant wanneer door afsterving van bladeren door droogte de fotosynthesecapaciteit beperkt is (Alberda 1970; Booysen en Nelson 1975). De persistentie van Engels raaigras types is onderzocht in het noorden van Nieuw Zeeland (Lee et al., 2017). Het aandeel Engels raaigras daalde in de eerste zomer naar 60\%, maar herstelde in de herfst naar meer dan $75 \%$. In een proef met Engels raaigras had de zodedichtheid, ofwel het aantal spruiten, bij droogte geen invloed op de opbrengst, maar wel op het herstel na de droogte (Barker et al. 1985). Reed et al. (2011) stelt bij verwachte langdurige droge omstandigheden mengsels van rassen moeten worden gezaaid met enerzijds rassen die in een goede zomerproductie hebben en anderzijds rassen die in de zomer in rust gaan, maar daardoor overleven en de zode kunnen herstellen.

Engels raaigras heeft een groot herstellingsvermogen, waardoor doorzaaien niet altijd nodig is (Haan et al., 2019). Beweide percelen op bedrijven van het project Koeien \& Kansen doorstonden in 2018 de droogte beter en herstelden door de veelal dichtere zode sneller, maar hier kan de leeftijd van het grasland ook doorheen hebben gespeeld. Beweiden kan onder erg droge omstandigheden wel extra schade aan de graszode veroorzaken.

De Haan et al. (2019) geeft op basis van onderzoek op De Marke en bij praktijkbedrijven (Koeien \& Kansen) in Nederland dat droogte ook nog gevolgen heeft voor de eerste snede het volgende voorjaar, met name door achteruitgang van de zodekwaliteit.

\subsection{Cultuur en Gebruikswaarden Onderzoek}

In het kader van het Cultuur en Gebruikswaarden Onderzoek (CGO) wordt namens de betrokken kwekers de Rassenlijst uitgebracht (Anonymus 2019) en hierin staat een overzicht van de waardering van verschillende eigenschappen van grassen en gebruiksdoelen. Volgens de Rassenlijst is voor het Nederlandse graslandgebruik Engels raaigras de meest geschikte en meest gezaaide grassoort, zeker voor percelen die 
voornamelijk worden beweid. Voor grasland dat uitsluitend wordt gemaaid komen ook andere grassoorten in aanmerking. Sinds halverwege de jaren zeventig uit de vorige eeuw worden opbrengsten van grasrassen bepaald onder maai en beweidingsomstandigheden. Dit geeft een beeld van de opbrengstontwikkeling, maar ook van de variatie tussen weerjaren en daarmee de opbrengstdepressie als gevolg van droogte.

De opbrengstverschillen tussen jaren is weergegeven in Figuur 4.1 met daarin de gemiddelde opbrengsten van de rassenproeven (Schils et al., 2020). Wat opvalt is de zeer lage opbrengst in het extreem droge jaar 1976. De hoge opbrengst van de maaiproeven ten opzichte van de beweidingsproeven in het eerste deel van de grafiek is een locatie effect. De maaiproeven lagen op kleigrond met hoge N-giften en de beweidingsproeven op een schrale zandgrond. Vanaf 1996 lagen de proeven op andere locaties en was de totale $\mathrm{N}$-gift minder hoog en waren de verschillen minder groot.

Schils et al. (2020) geeft aan dat zowel droogte als het aantal dagen met vorst gedurende het groeiseizoen een negatief effect hadden op de opbrengst.

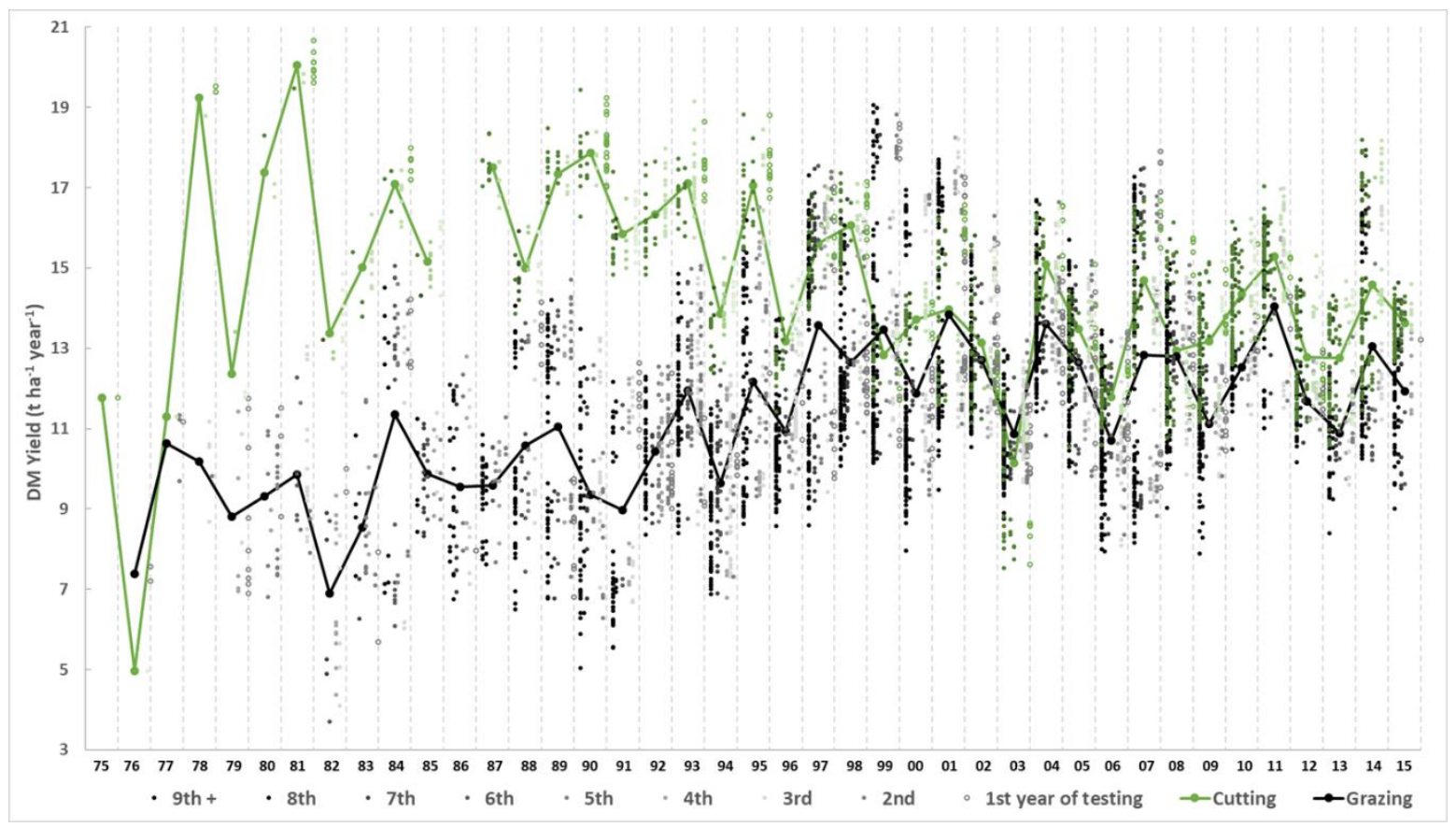

Figuur 4.1 Opbrengstverschillen van de CGO proeven (uit Schils, 2020).

In het rassenonderzoek (CGO) voor de Rassenlijst worden jaarlijks beweidingsproeven en maaiproeven uitgezaaid met rassen van Engels raaigras. Om de twee jaar wordt een maaiproef op kleigrond aangelegd. De overige proeven liggen op zandgrond. In de proeven worden nieuw aangemelde rassen vergeleken met de rassenlijstrassen. De overige grassoorten en klaver worden minder frequent uitgezaaid. De bezetting met het ingezaaide gras wordt jaarlijks gescoord en in het $2^{\mathrm{e}}, 3^{\mathrm{e}}$ en $4^{\mathrm{e}}$ jaar wordt de drogestofopbrengst bepaald. De best presterende rassen worden in de rassenlijst opgenomen (www.rassenlijstinfo.nl).

\section{Opbrengst}

De gemiddelde drogestofopbrengst van de CGO proeven in de periode 2010-2017 was van de Rassenlijsrassen 13.2 ton per ha (Van der Schoot, 2018). In de daaropvolgende droge, warme jaren 2018 en 2019 was de opbrengst van de CGO proeven beduidend lager. In 2018 was de opbrengst gemiddeld over de proeven 8.7 ton ds/ha en in 2019 gemiddeld 10.7 ton ds/ha.

\section{Bezetting en persistentie}

In de rassenproeven wordt jaarlijks in november de bezetting waargenomen. Bij de beste rassen neemt de bezetting als gevolg van het gebruik en de weersomstandigheden niet of nauwelijks af. Deze rassen hebben een goede persistentie. Bij minder persistente rassen daalt de bezetting met als resultaat een opener zode en meer ongewenste grassen als ruwbeemd en kweek en meer onkruiden. 
De gemiddelde bezetting van alle uitgezaaide rassen van Engels raaigras, bekeken over de zand- en kleiproeflocaties tezamen, verschilde niet tussen de jaren 2008-2017 en de zeer droge jaren 2018 en 2019 . De gemiddelde jaarlijkse afname in bezetting was $1,3 \%$, waarbij de laat doorschietende rassen een wat lagere afname vertonen ten opzichte van de rassen uit de middentijdse groep.

De diploïde rassen waren gemiddeld wat persistenter dan de tetraploïde rassen ( $1 \%$ respectievelijk $1,8 \%$ ). Er was een grondsoortverschil te onderscheiden. Op kleigrond was de afname in bezetting gemiddelde over de hele periode 2008-2019 significant minder groot dan op zandgrond ( $0,6 \%$ respectievelijk 1,5\%). Zie onderstaande Tabel 9.

Tabel 9 Verandering bezetting van Engels raai afhankelijk van ploidi en grondsoort. Daarbij zijn de mate van significatie aangegeven (F-prob) en de overschrijdingskans (LSD 5\%).

\begin{tabular}{lccc}
\hline Ploïdi & Bezetting (\%) & Grondsoort & Bezetting (\%) \\
\hline Diploïd & -1.03 & Klei & 0.59 \\
\hline Tetraploïd & -1.75 & Zand & -1.49 \\
\hline F-prob & 0.04 & F-prob & 0.05 \\
\hline LSD 5\% & 0.95 & LSD 5\% & 0.99
\end{tabular}

De verschillen in afname in bezetting was tussen de jaren significanter dan de verschillen tussen ploïdi en grondsoort. Daarbij is onderscheid te maken tussen de grondsoorten klei en zand. Waar de afname op kleigrond zeer beperkt was in de jaren 2018 en 2019, was de afname op zandgrond aanmerkelijk hoger, vooral in 2019. Het valt op dat de afname in 2016 relatief groot was met 4,2\% op zandgrond. In dit jaar was het voorjaar relatief nat en is eind juni in de zuidelijke helft van Nederland lokaal veel neerslag gevallen. Behalve droogte hadden ook juist nattere jaren - met berijdings- en vertrappingschade - en winters met vorstschade een negatief effect op de grasbezetting. De afname in bezetting per waarnemingsjaar en grondsoort staat in Tabel 10.

Tabel 10 Verandering bezetting Engels raaigras per jaar en grondsoort in de CGO proeven 2008-2019.

\begin{tabular}{lccc}
\hline Waarnemingsjaar & $\begin{array}{l}\text { Verandering bezetting } \\
\text { op zand- en kleigrond (\%) }\end{array}$ & $\begin{array}{l}\text { Verandering bezetting } \\
\text { op kleigrond (\%) }\end{array}$ & $\begin{array}{c}\text { Verandering bezetting } \\
\text { op zandgrond (\%) }\end{array}$ \\
\hline 2008 & $-0,1$ & $-0,6$ & 0,0 \\
\hline 2009 & $-1,3$ & 0,7 & $-1,6$ \\
\hline 2010 & $-1,3$ & $-1,7$ & $-1,2$ \\
\hline 2011 & $-2,3$ & $-0,1$ & $-2,6$ \\
\hline 2012 & $-2,3$ & $-1,9$ & $-2,3$ \\
\hline 2013 & $-0,1$ & $-0,2$ & $-0,1$ \\
\hline 2014 & $-1,6$ & $-0,5$ & $-1,7$ \\
\hline 2015 & 0,9 & $-2,2$ & 1,3 \\
\hline 2016 & $-4,0$ & $-1,8$ & $-4,2$ \\
\hline 2017 & 1,1 & 1,2 & 1,1 \\
\hline 2018 & $-1,2$ & 0,4 & $-1,3$ \\
\hline 2019 & $-3,6$ & $-0,1$ & $-4,0$ \\
\hline F-prob & $<0,001$ & & \\
\hline LSD 5\% & 2,2 & & \\
\hline
\end{tabular}

Op basis van de getallen in Tabel 10 zijn de jaren 2008-2017 met weinig vochttekort en de warme droge jaren 2018-2019 vergeleken. De afname in bezetting op zandgrond was in 2018-2019 met 2,7 \% groter dan gemiddeld in voorgaande 'normale' jaren met 1,1\%. Zie Tabel 11. 
Tabel 11 Verandering bezetting Engels raaigras in relatief normale weerjaren 2008-2017 ten opzichte van de droge warme jaren 2018-2019.

\begin{tabular}{lcc}
\hline Waarnemingsjaren & $\begin{array}{c}\text { Verandering bezetting } \\
\text { op kleigrond (\%) }\end{array}$ & $\begin{array}{c}\text { Verandering bezetting } \\
\text { op zandgrond (\%) }\end{array}$ \\
\hline $2008-2017$ & $-0,7$ & $-1,1$ \\
\hline $2018-2019$ & 0,1 & $-2,7$ \\
\hline
\end{tabular}

De verschillen in persistentie tussen de rassen waren echter groot en ook groter dan de effecten van jaar, grondsoort en type. In Figuur 4.2 is de gemiddelde bezetting van de onderzochte rassen uitgezet tegen de jaarlijks afname van de bezetting, waarbij elk bolletje een ras voorstelt. Hierbij is onderscheid gemaakt in de periode 2010-2017 (blauw) en de periode 2018 en 2019 (oranje). Elk bolletje is een rasgemiddelde van de betreffende jaren. Een gemiddelde bezetting van b.v. $70 \%$ kan betekenen dat er proeven bij zaten waar de bezetting na vier jaar nog $80 \%$ was, maar ook proeven met een bezetting na vier jaar van maar $60 \%$ of lager.

Rassen met een goede persistentie, ofwel een gemiddelde bezetting van $85 \%$ behielden hun bezetting gedurende de duur van de proef van 4 jaar, zowel in de periode 2010-2017 als in de jaren 2018 en 2019 . De bezetting van de rassen met een minder goede persistentie daalde in de onderzoeksperiode. Uit de grafiek is af te lezen dat de afname in bezetting van de minder persistente rassen in de warme droge jaren 2018 en 2019 veel groter was in vergelijking met de 10 jaar daarvoor.

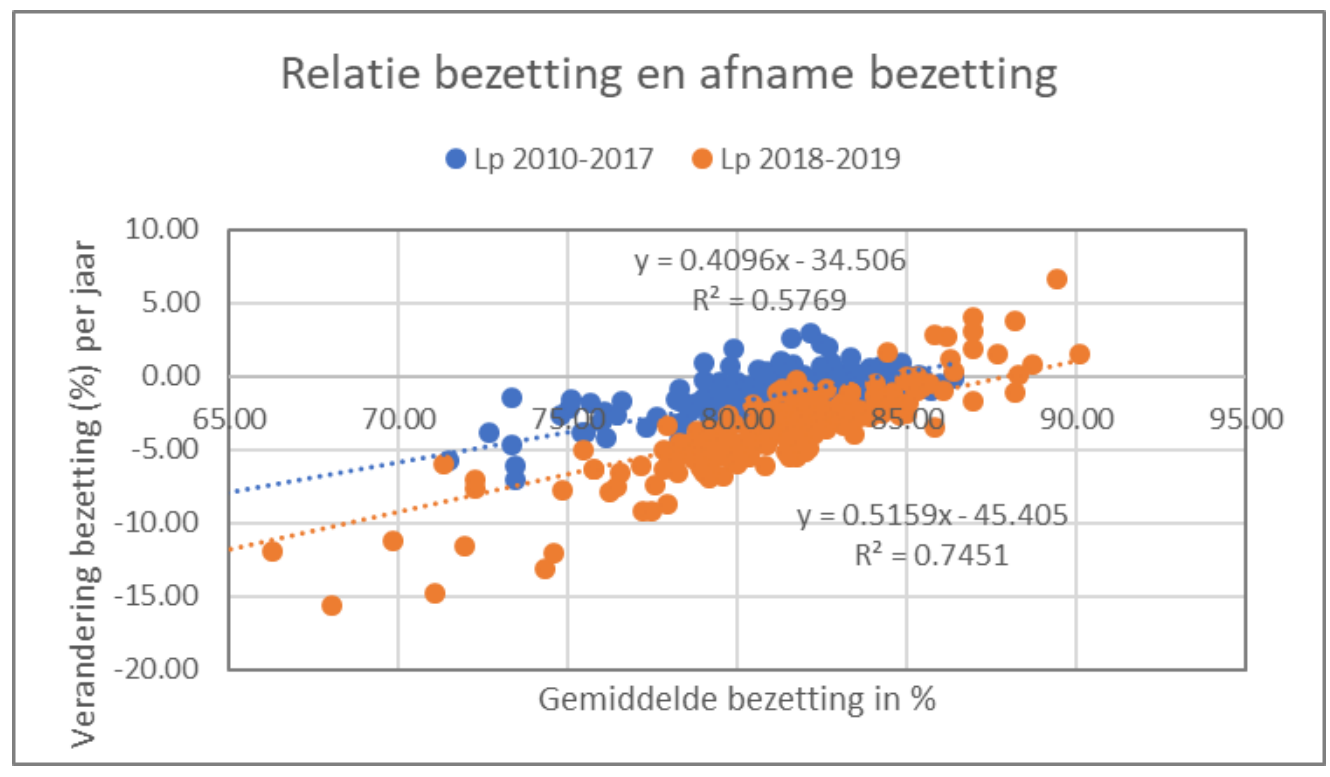

Figuur 4.2 Relatie bezetting Engels raaigras ( $L p)$ en de verandering in bezetting per jaar over de periode 2010-2017 en de periode 2018-2019.

\subsection{Schadedrempel herinzaai}

De literatuur gaf geen directe aanknopingspunten om de persistentie van Engels raaigras of andere goede grasrassen en de achteruitgang in bezetting te kunnen relateren aan droogtestress. Het meest concreet is de CGO-data waaruit blijkt dat op zandgrond de afname van de bezetting van Engels raai in de relatief droge jaren 2018-2019 groter was dan in de voorgaande jaren 2010-2017.

De standaard afname van de bezetting gedurende een lange periode 2010-2017 is als uitgangspunt genomen voor de beantwoording van de eerste onderzoeksvraag (zie Hoofdstuk 1), namelijk het vinden van een opbrengstdepressiepercentage waar beneden de frequentie voor herinzaai niet varieert (drempelwaarde). Het betreffende opbrengstdepressiepercentage volgde uit de bedrijfsberekeningen (zie 
paragraaf 5.3.2). In het onderstaande is volgens de normen die in het CGO-onderzoek worden gehanteerd een herinzaaipercentage voor deze drempelwaarde afgeleid.

De gemiddelde afname van de bezetting van Engels raaigras (aandeel Engels raai en de openheid van de graszode) op zandgrond bedroeg 1,1 \%. Volgens de normen die in het CGO-onderzoek worden gehanteerd is het aandeel herinzaai volgens onderstaande stappen afgeleid:

Herinzaaipercentage drempelwaarde droogtestress

1. De gemiddelde afname van de bezetting van Engels raaigras op zandgrond bedroeg $1,1 \%$.

2. Een goede graszode heeft een gemiddelde bezetting van tenminste $85 \%$

3. Een zode met minimale kwaliteit heeft een gemiddelde bezetting van tenminste $70 \%$ Bij dit percentage mag verwacht worden dat de zode snel verder achteruitgaat (zie Figuur 4.2)

4. Opnieuw herinzaaien na $(85-70 \%) / 1,1 \%=14$ jaar (afgerond op gehele jaren)

5. De drempelwaarde voor het herinzaaipercentage bedraagt $100 / 14=\mathbf{7 , 1} \%$

\subsection{Extra herinzaai door toename droogtestress}

Voor het beantwoorden van de tweede onderzoeksvraag, namelijk wat de relatie is tussen de toename van het opbrengstdepressiepercentage en de frequentie van herinzaai door grondwaterwinning, is de extra herinzaai door extra droogtestress bepaald op basis van de afname van de bezetting van Engels raaigras in de extreem droge jaren van 2018-2019.

\section{Herinzaaipercentage maximale droogtestress}

1. De extra afname van de bezetting van Engels raaigras op zandgrond bij extreme droogte (20182019) bedroeg gemiddeld $2,7 \%$.

2. Verondersteld is dat deze extra afname aan de orde is bij de hoogste opbrengstdepressiepercentage die volgde uit de bedrijfsberekeningen (bodemtype leemarm, variant Waterwinning 2).

3. Opnieuw herinzaaien na ( $85-70 \%) / 2,7 \%=6$ jaar (afgerond op gehele jaren)

4. Het herinzaaipercentage bedraagt $100 / 6=\mathbf{1 6 . 7} \%$

De herinzaaipercentages voor de drempelwaarde en de maximale droogtestress zijn als uitgangspunt genomen voor de onderbouwing van de normbedragen voor de kosten van extra herinzaai. Door extra droogtestress nam het herinzaaipercentage op zandgrond toe van 7,1 naar $16,7 \%$. Dit is het bereik waarbinnen opbrengstdepressiepercentages vallen die volgden uit de bedrijfsberekeningen (zie paragraaf 5.3.2). Door middel interpolatie tussen deze twee herinzaaipercentages zijn de opbrengstdepressie vertaald in een herinzaaifrequentie (zie paragraaf 6.1). Uit deze herinzaaifrequenties zijn de normbedragen berekend (zie paragraaf 6.2). 


\section{$5 \quad$ Resultaten modelberekeningen}

\section{$5.1 \quad$ Algemeen}

De modelberekeningen zijn in de eerste plaats uitgevoerd om het effect van droogte op de grasproductie en daarmee het effect op de voedervoorziening op bedrijfsniveau te bepalen. Deze normatieve bepalingen zijn vervolgens in Hoofdstuk 6 gebruikt om de normbedragen voor herinzaai vast te stellen. In de volgende paragrafen worden de resultaten voor wat betreft de grondwaterstand, de vochtvoorziening (drukhoogte), de grasproductie en de zelfvoorziening voor ruwvoer uiteengezet. De drukhoogte is een maat voor de zuigspanning die plantenwortels in de bodem moeten overbruggen om vocht aan de bodem te onttrekken. Bij een stijgende drukhoogte neemt de vochtbeschikbaarheid af. Voor gras en snijmaïs is de gemiddelde kritieke grens voor (gedeeltelijke) sluiting huidmondjes en afname gewasgroei $500 \mathrm{~cm}$. Dit is tevens het punt waarop droogtestress zichtbaar wordt.

\subsection{Grondwater en drukhoogte en draagkracht}

\subsubsection{Grondwaterstand}

Het gemiddelde grondwaterstandsverloop van de twintig weerjaren (2000-2019) staat in Figuur 5.1. Het betreft hierbij de grondwaterstanden in de periode van 1 januari tot en met 31 december. In Bijlage 1 staat het grondwaterstandsverloop voor de gehele reeks van weerjaren.

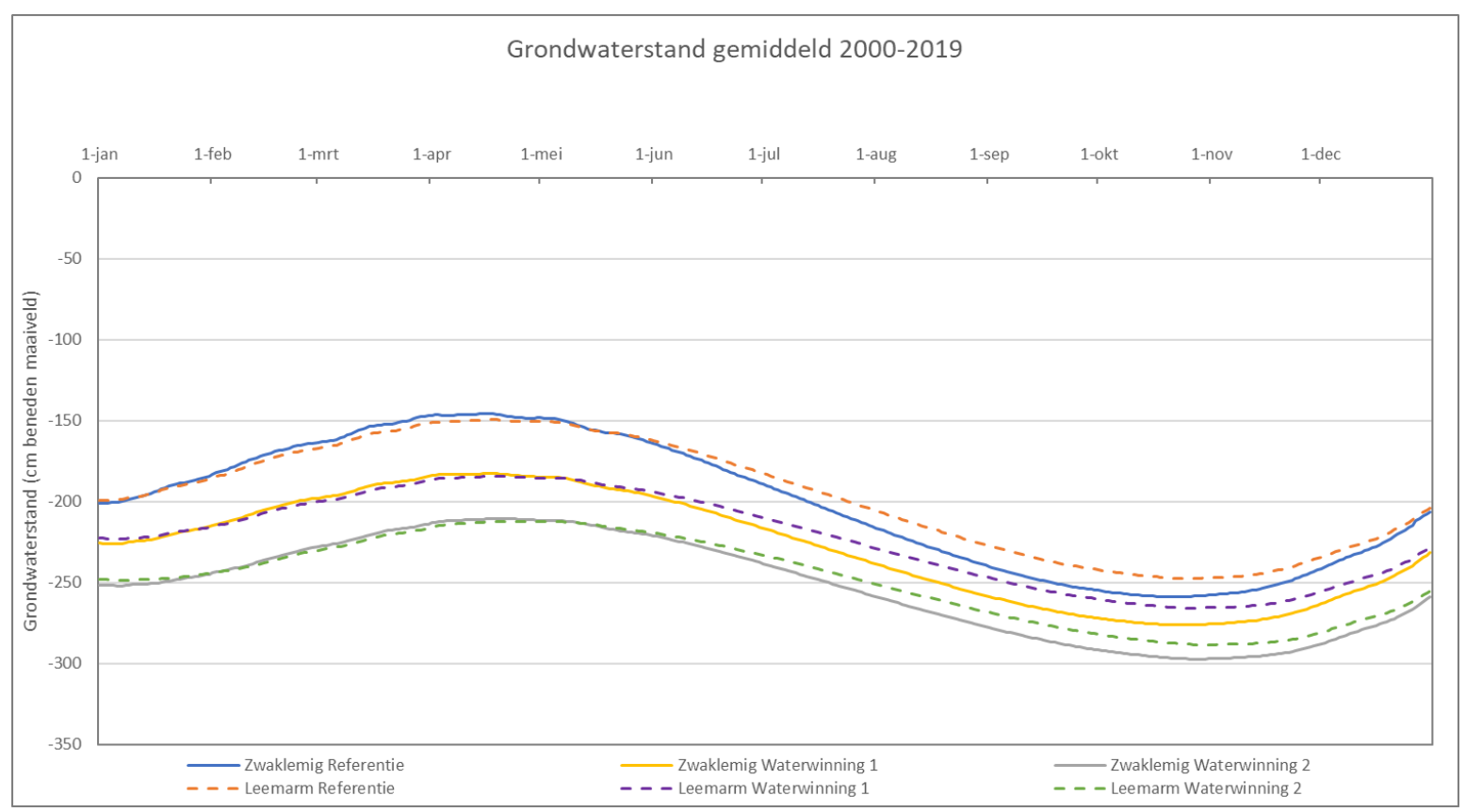

Figuur 5.1 Gesimuleerde grondwaterstand van 1 januari tot en met 31 december gemiddeld over de reeks van weerjaren 2000-2019 voor de bodemtypen Leemarm en Zwak lemig fijn zand en de droogtevarianten Referentie, Waterwinning 1 en Waterwinning 2 voor melkveeproefbedrijf De Marke.

Grondwateronttrekking laat een daling zien van de laagste grondwaterstand afhankelijk van de mate van onttrekking en het bodemtype. De daling is groter voor een zwaklemige grond dan voor een leemarme bodem door de grotere mate van gewasverdamping. Op een leemarme grond wordt gewasverdamping sneller beperkt door een geringer vochtleverend vermogen van de bodem. 
Het effect op de bodemtype en grondwateronttrekking is gekwantificeerd door de GLG te berekenen (zie paragraaf 3.4). In Tabel 12 staan per bodemtype en droogtevariant de GLG gemiddeld over de reeks van 20 weerjaren berekend met SWAP (voorbereidende berekening) en met Waterpas. Met Waterpas bleek de verdamping verder gereduceerd te worden.

Tabel 12 Gemiddeld Laagste Grondwaterstand (GLG) per bodemtype en droogtevariant 2000-2019 voor melkveeproefbedrijf De Marke berekend met SWAP (simulatie stijghoogteverloop) en met Waterpas (bedrijfsberekeningen).

\begin{tabular}{|c|c|c|c|}
\hline Bodemtype & Variant & $\begin{array}{c}\text { GLG SWAP } \\
\text { (cm beneden maaiveld) }\end{array}$ & $\begin{array}{c}\text { GLG Waterpas } \\
\text { (cm beneden maaiveld) }\end{array}$ \\
\hline \multirow[t]{3}{*}{ Leemarm } & Referentie & 245 & 248 \\
\hline & Waterwinning 1 & 264 & 267 \\
\hline & Waterwinning 2 & 286 & 289 \\
\hline \multirow[t]{3}{*}{ Zwaklemig } & Referentie & 255 & 259 \\
\hline & Waterwinning 1 & 275 & 277 \\
\hline & Waterwinning 2 & 296 & 298 \\
\hline
\end{tabular}

\subsubsection{Drukhoogte}

Het gemiddelde drukhoogteverloop in de wortelzone van de twintig weerjaren (2000-2019) staat in Figuur 5.2. Het betreft hierbij de drukhoogtes in de periode van 1 januari tot en met 31 december. In Bijlage 2 staat het grondwaterstandsverloop voor de gehele reeks van weerjaren.

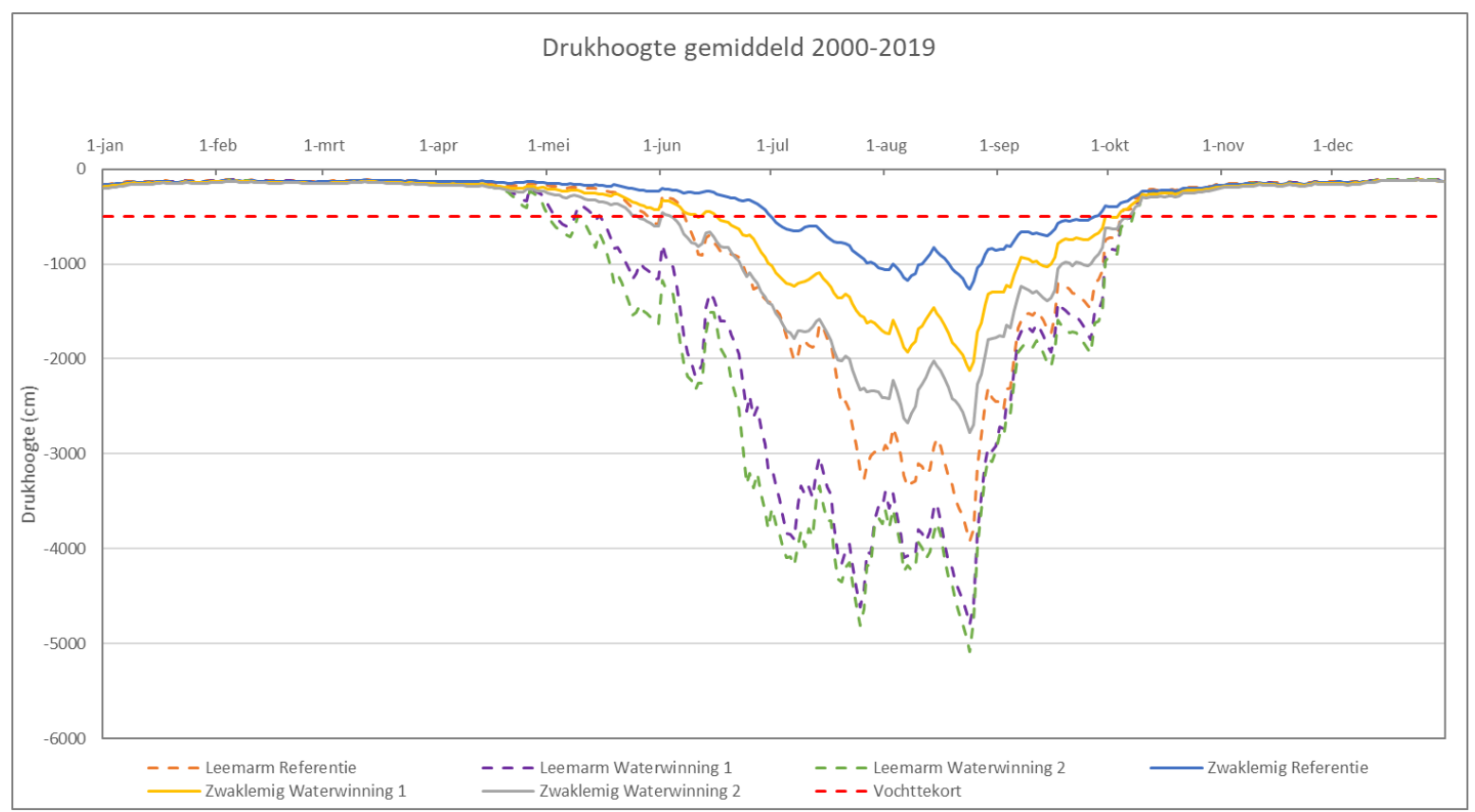

Figuur 5.2 Gesimuleerde drukhoogte van 1 januari tot en met 31 december gemiddeld over de reeks van weerjaren voor de bodemtypen Leemarm en Zwak lemig fijn zand en de droogtevarianten Referentie, Waterwinning 1 en Waterwinning 2 voor melkveeproefbedrijf De Marke. De grens waarbij vocht gemiddeld beperkend wordt voor grasgroei $(500 \mathrm{~cm})$ is aangegeven.

Evenals voor de grondwaterstanden laten beide bodemtypen en de drie droogtevarianten een verschil zien in het drukhoogteverloop. Het verschil tussen leemarm en zwak lemig is daarbij aanzienlijk en komt tot uitdrukking in de berekende grasopbrengsten (paragraaf 5.3.1). 


\subsection{Technische bedrijfsresultaten}

\subsubsection{Grasproductie}

De belangrijkste kengetallen voor de ruwvoerproductie voor de potentiele groei en voor de twee bodemtypen Zwak lemig en leemarm bij de varianten Referentie en Waterwinning 1 en Waterwinning 2 staan in Bijlage 3, met in Tabel 1 de gemiddelde waarden, in Tabel 2 de standaarddeviatie, in Tabel 3 de minimale waarden, Tabel 4 de maximale waarden en Tabel 5 de verschillen met de referentie.

De gemiddelde bruto drogestofopbrengst en de netto energieopbrengst van gras (kVEM) per ha inclusief de kwartielwaarden en uiterste waarden staat per variant grafisch weergegeven in Figuur 5.3. Hierbij is de opbrengst tot stand gekomen door zowel weiden als maaien. De netto grasopbrengst betreft de bruto grasopbrengst verminderd met verliezen voor weideresten bij weiden, oogstverliezen bij ruwvoerwinning (maaien) en conserveringsverliezen bij inkuilen en van het geoogste gras. De energieopbrengst is uitgedrukt in de hoeveelheid energie die het voer bevat om door koeien melk van te produceren. De eenheid hiervoor is VEM (Voeder Eenheid Melk).

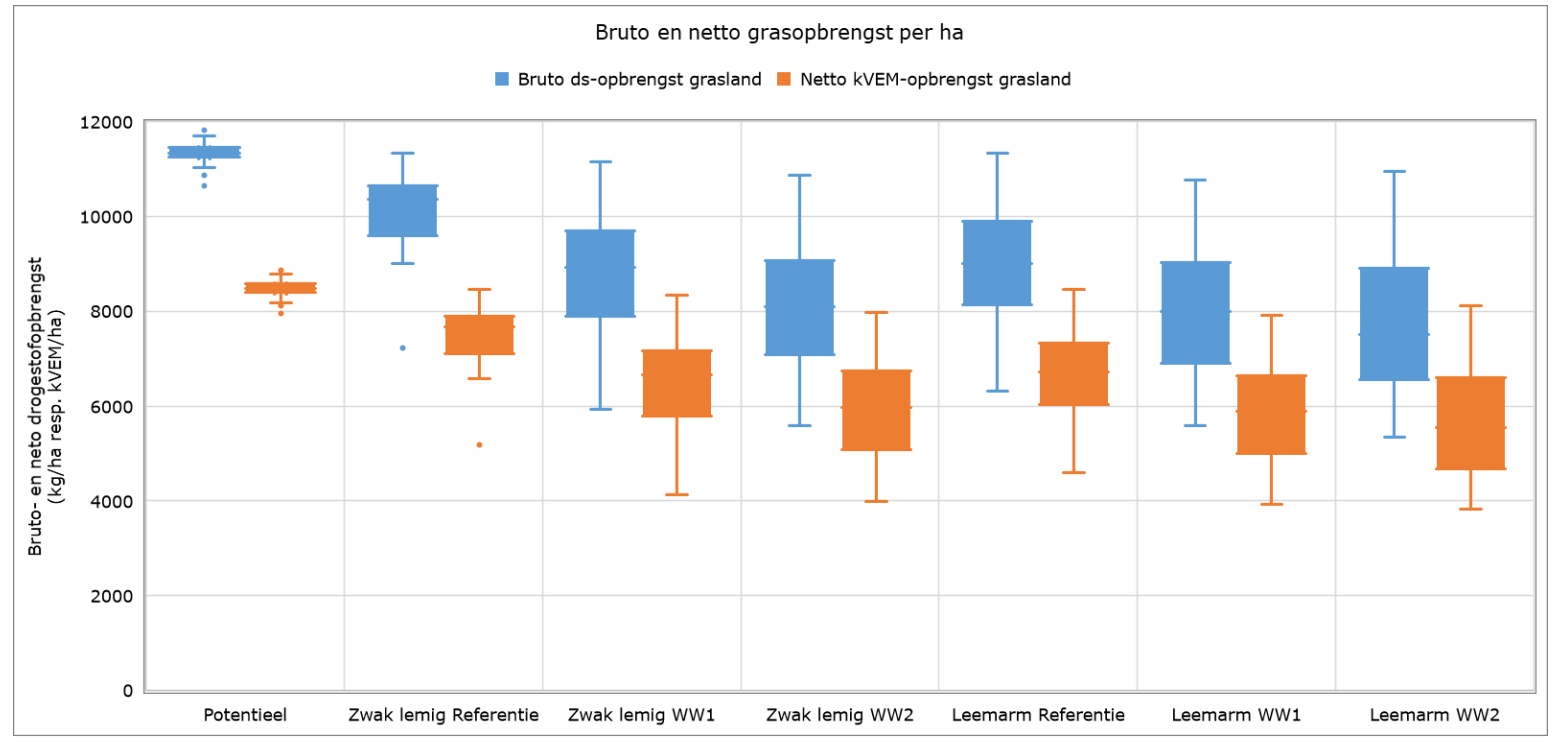

Figuur 5.3 Gesimuleerde bruto drogestofopbrengst en energie-opbrengst (kVEM) van gras per ha per jaar (weiden en maaien) potentieel en voor twee bodemtypen en de drie droogtevarianten Referentie, Waterwinning 1 en Waterwinning 2 gemiddeld over een reeks van 20 weerjaren (2000-2019) voor melkveeproefbedrijf De Marke. De weergegeven kaders en lijnen betreffen de verdeling van resultaten in kwartielen, met de mediaan en de uitschieters. De verticale lijnen geven variabiliteit buiten het bovenste en onderste kwartiel aan en punten buiten die lijnen betreffen sterk afwijkende waarden.

Door droogte als gevolg van wateronttrekking voor grondwaterwinning daalde de gesimuleerde productie naarmate de droogte toenam zoals verwacht werd. De berekeningen kwantificeren de afname van de bruto en netto energieopbrengst en laten zien dat de variatie tussen weerjaren toenam, vooral voor het bodemtype Leemarm. De gemiddelde bruto opbrengstniveaus zijn gebruik voor het berekenen van de normbedragen voor herinzaai (zie Hoofdstuk 6 Normbedragen extra herinzaai).

\subsubsection{Droogteschade}

De verandering van de bruto grasproductie ten opzichte van de potentiële bruto productie is vertaald in schade percentages voor directe en indirecte schade. De percentages directe en indirecte schade staan in Tabel 13. 
Tabel 13 Directe en indirecte schade bruto grasproductie voor de gesimuleerde droogtevarianten voor twee bodemtypen en drie droogtevarianten gemiddeld over periode 2000-2019 voor melkveeproefbedrijf De Marke.

\begin{tabular}{lcccc}
\hline Varianten & $\begin{array}{l}\text { Directe schade } \\
\text { nat (\%) }\end{array}$ & $\begin{array}{l}\text { Directe schade droog } \\
(\%)\end{array}$ & $\begin{array}{l}\text { Indirecte } \\
\text { schade (\%) }\end{array}$ & $\begin{array}{l}\text { Totaal } \\
(\%)\end{array}$ \\
\hline Zwaklemig & & & 0,0 & 11.3 \\
\hline Referentie & 0,0 & 11.3 & 0,0 & 21.8 \\
\hline Waterwinning 1 & 0,0 & 21.8 & 0,0 & 28.1 \\
\hline Waterwinning 2 & 0,0 & 28.1 & & 20.5 \\
\hline Leemarm & & & 0,0 & 29.7 \\
\hline Referentie & 0,0 & 20.5 & 0,0 & 32.2 \\
\hline Waterwinning 1 & 0,0 & 29.7 & 0,0 & 32.2 \\
\hline Waterwinning 2 & 0,0 & & & 0 \\
\hline
\end{tabular}

De grasopbrengst werd uitsluitend gereduceerd door droogte (directe schade). Schade door vernatting in het vroege voorjaar of late najaar trad niet op. Ook beperkingen in het graslandgebruik, anders dan veroorzaakt door verminderde productie (indirecte schade), traden niet op.

\subsubsection{Verdeling grasopbrengst}

De totale bruto grasopbrengst op bedrijfsniveau per variant voor de eerste en de overige sneden voor gangbaar grasland inclusief de kwartielwaarden en uiterste waarden staan in Figuur 5.4. De totale productie is bepalend voor de mate van zelfvoorziening in ruwvoer en de hoeveelheid voer die aangekocht moet worden om een tekort te compenseren.

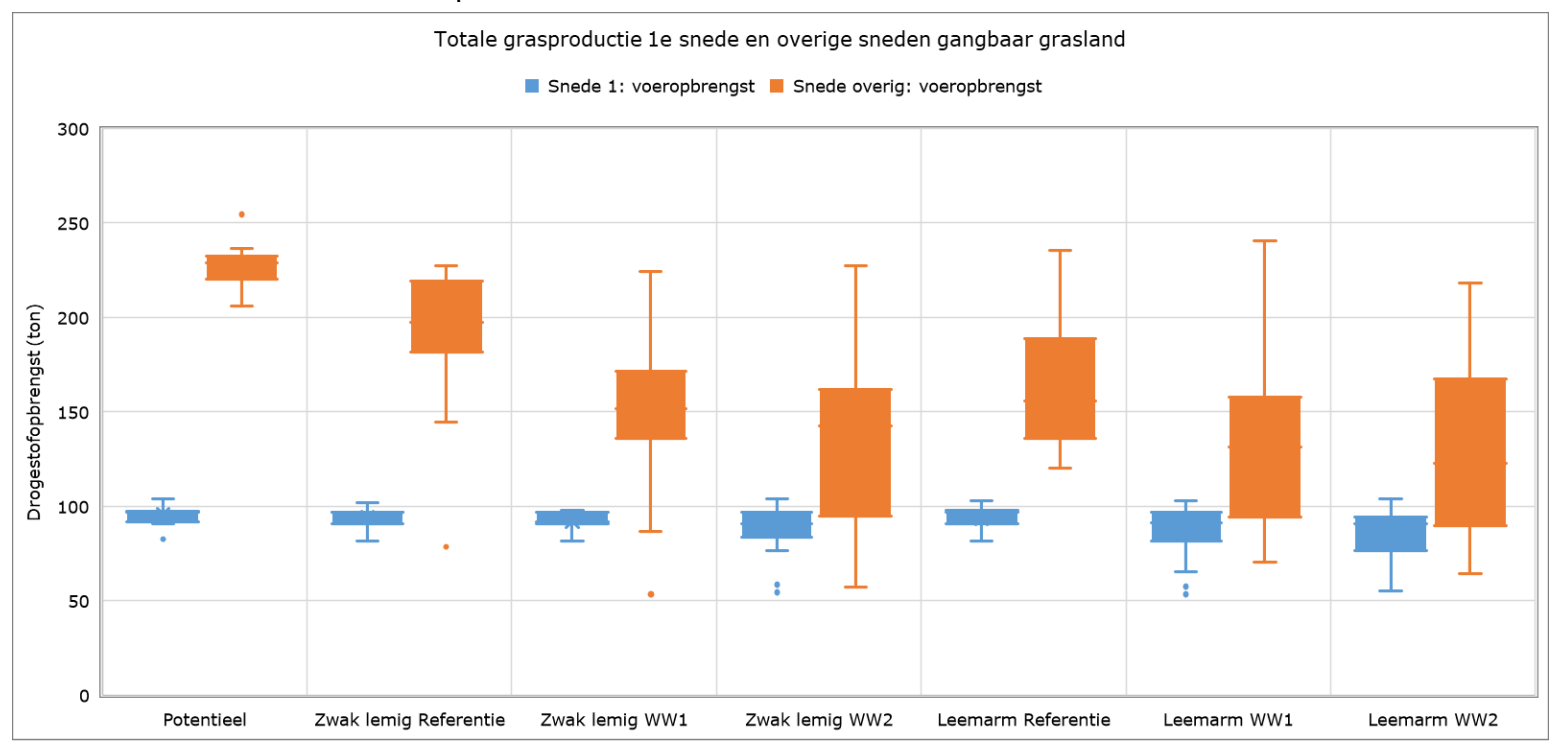

Figuur 5.4 Gesimuleerde totale grasproductie van de eerste en overige sneden op bedrijfsniveau voor twee bodemtypen en de drie droogtevarianten Referentie, Waterwinning 1 en Waterwinning 2 gemiddeld over een reeks van 20 weerjaren (2000-2019) voor melkveeproefbedrijf De Marke. De weergegeven kaders en lijnen betreffen de verdeling van resultaten in kwartielen, met de mediaan en de uitschieters. De verticale lijnen geven variabiliteit buiten het bovenste en onderste kwartiel aan en punten buiten die lijnen betreffen sterk afwijkende waarden.

Het verschil in grasproductie kwam na de eerste snede (vroege voorjaar) tot uitdrukking in de overige sneden. Door de afnemende grasproductie door extra droogte verminderde ook de totale grasproductie op bedrijfsniveau. Evenals voor de grasopbrengsten per ha nam vooral voor het bodemtype Leemarm de variatie tussen weerjaren toe door extra droogte. 


\subsubsection{Aandeel maaien eerste en overige sneden}

De gemiddelde percentages maaien per variant voor de eerste en de overige sneden voor gangbaar grasland inclusief de kwartielwaarden en uiterste waarden staan in Figuur 5.5. Maaien verhoogt de kosten ten opzichte van weiden en is van belang voor een verdere economische analyse van het effect van droogte op het bedrijfsinkomen (zie Hoofdstuk 7 Discussie).

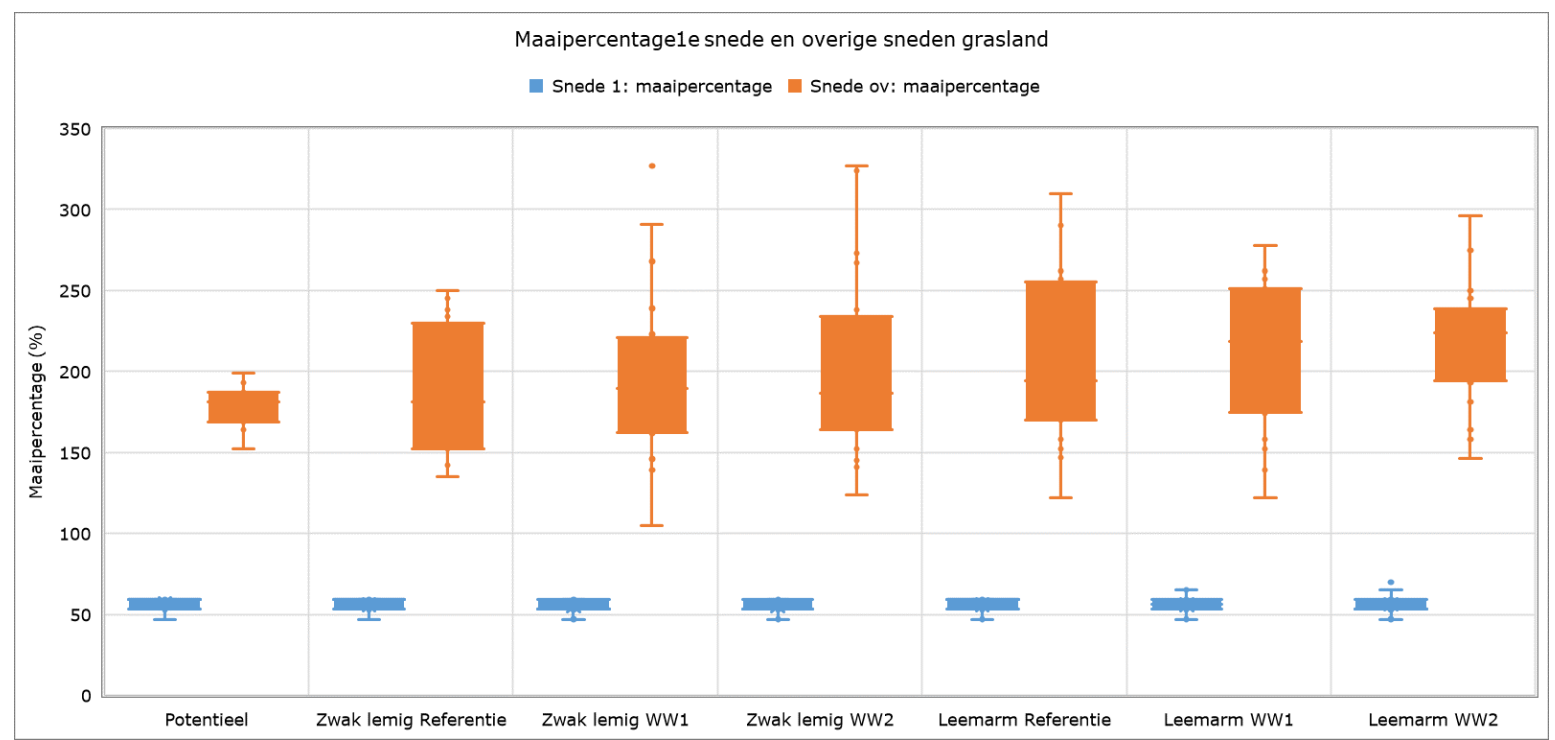

Figur 5.5 Gesimuleerde maaipercentage eerste en overige sneden grasland voor twee bodemtypen en de drie droogtevarianten Referentie, Waterwinning 1 en Waterwinning 2 gemiddeld over een reeks van 20 weerjaren (2000-2019) voor melkveeproefbedrijf De Marke. De weergegeven kaders en lijnen betreffen de verdeling van resultaten in kwartielen, met de mediaan en de uitschieters. De verticale lijnen geven variabiliteit buiten het bovenste en onderste kwartiel aan en punten buiten die lijnen betreffen sterk afwijkende waarden.

Het maaipercentage voor de overige sneden nam voor Zwak lemig voor de twee droogte varianten in beperkte mate toe, met respectievelijk $9 \%$ voor Waterwinning 1 en $6 \%$ voor Waterwinning 2 . Voor Leemarm was de toename ten opzichte van de Referentie gemiddeld $24 \%$ voor Waterwinning 1 en $29 \%$ voor Waterwinning 2.

\subsubsection{Zelfvoorziening ruwvoer}

De zelfvoorzieningsgraad voor ruwvoer voor alle varianten inclusief de kwartielwaarden en uiterste waarden staan in Figuur 5.6. Een verandering van de zelfvoorzieningsgraad geeft een verandering in de aankoop van ruwvoer. De voerkosten maken een relatief groot deel uit van de totale (toegerekende en niet toegerekende) kosten op een melkveebedrijf (zie Hoofdstuk 7 Discussie). 


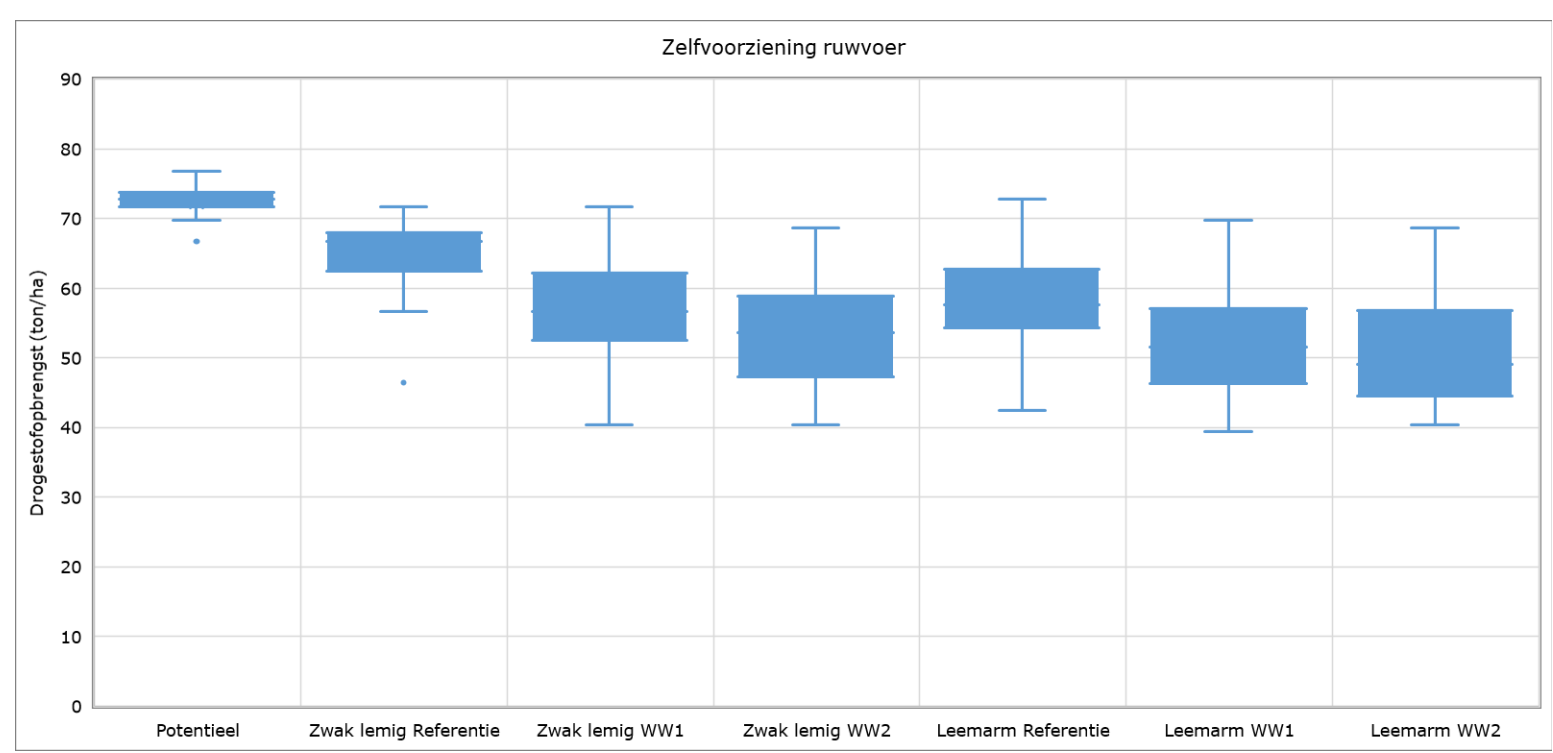

Figuur 5.6 Gesimuleerde zelfvoorzieningsgraad ruwvoerwinning voor twee bodemtypen en de drie droogtevarianten Referentie, Waterwinning 1 en Waterwinning 2 gemiddeld over een reeks van 20 weerjaren (2000-2019) voor melkveeproefbedrijf De Marke. De weergegeven kaders en lijnen betreffen de verdeling van resultaten in kwartielen, met de mediaan en de uitschieters. De verticale lijnen geven variabiliteit buiten het bovenste en onderste kwartiel aan en punten buiten die lijnen betreffen sterk afwijkende warden.

Voor Zwak lemig nam de zelfvoorzieningsgraad ten opzichte van de Referentie af met $10 \%$ voor Waterwinning 1 en $13 \%$ voor Waterwinning 2. Voor Leemarm was de afname ten opzichte van de Referentie $6 \%$ voor Waterwinning 1 en $9 \%$ voor Waterwinning 2 . De afname verhoogt de kosten voor de aankoop van ruwvoer.

\subsubsection{Grasopname melkvee}

De belangrijkste kengetallen voor de voeropname voor de gesimuleerd varianten staan in Bijlage 4, met in Tabel 1 de gemiddelde waarden, in Tabel 2 de standaarddeviatie, in Tabel 3 de minimale waarden en in Tabel 4 de maximale waarden. De grasopname bij weiden is een kengetal voor de mate van weidegang. De gemiddelde grasopname per koe per jaar en de verdeling tussen de weerjaren per variant staat in Figuur 5.7 . 


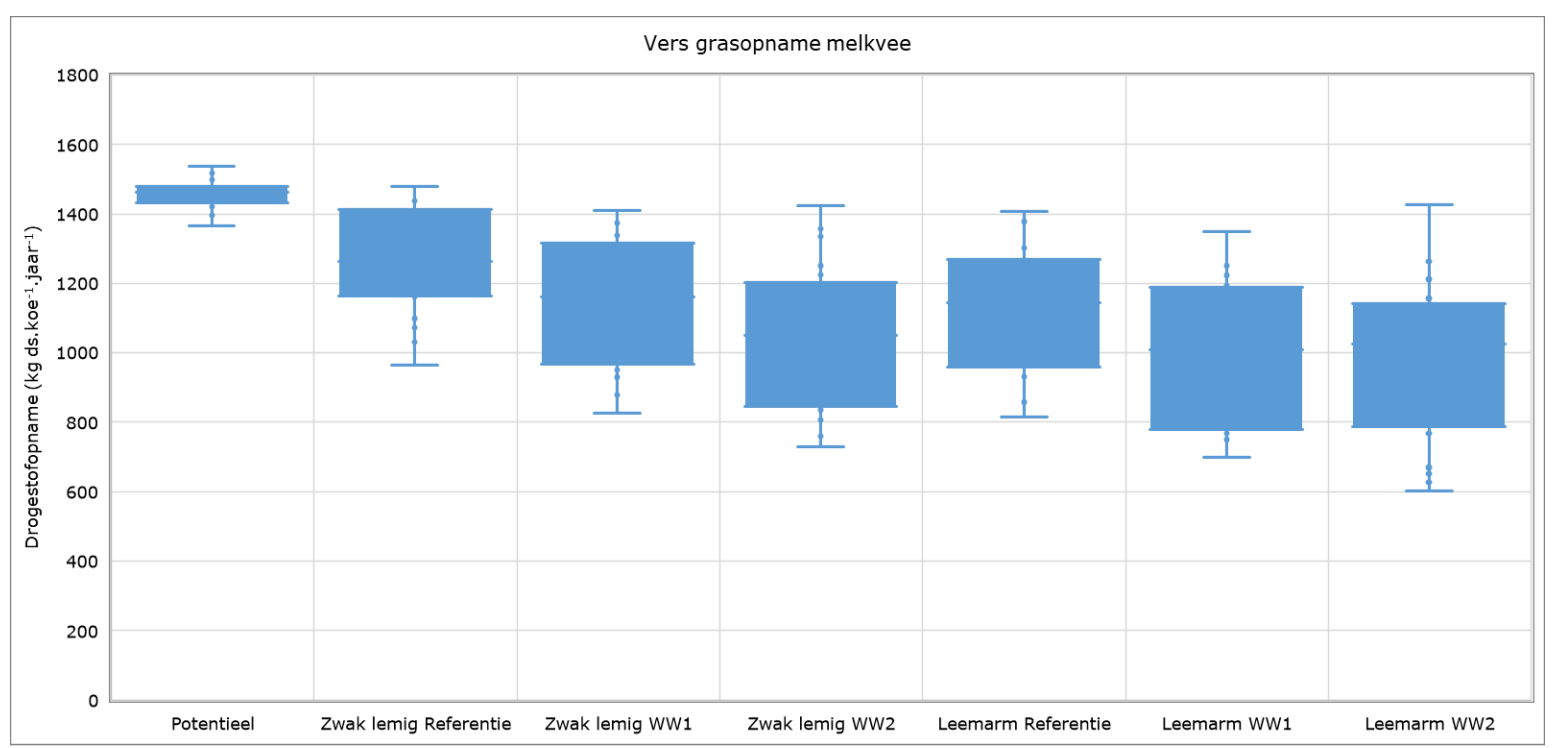

Figuur 5.7 Gesimuleerde vers grasopname melkvee voor twee bodemtypen en de drie droogtevarianten Referentie, Waterwinning 1 en Waterwinning 2 gemiddeld over een reeks van 20 weerjaren (2000-2019) voor melkveeproefbedrijf De Marke. De weergegeven kaders en lijnen betreffen de verdeling van resultaten in kwartielen, met de mediaan en de uitschieters. De verticale lijnen geven variabiliteit buiten het bovenste en onderste kwartiel aan en punten buiten die lijnen betreffen sterk afwijkende waarden.

De vermindering van de grasopbrengst door droogte zorgde ook voor een vermindering van de vers grasopname door melkvee. Voor Zwak lemig daalde de vers grasopname gemiddeld met $104 \mathrm{~kg}$ droge stof voor Waterwinning 1 en $213 \mathrm{~kg}$ droge stof voor Waterwinning 2. Voor Leemarm was de afname ten opzichte van de Referentie gemiddeld $135 \mathrm{~kg}$ droge stof voor Waterwinning 1 en $121 \mathrm{~kg}$ droge stof voor Waterwinning 2 . 


\section{$6 \quad$ Normbedragen extra herinzaai}

\subsection{Grasproductie extra herinzaai}

De herinzaaipercentages voor de drempelwaarde $(7,1 \%)$ en de maximale droogtestress $(16,7 \%)$ vormden het bereik waarbinnen de opbrengstdepressiepercentages vielen, die volgden uit de bedrijfsberekeningen. Door middel van interpolatie tussen deze twee percentages zijn de berekende opbrengstdepressies voor de varianten vertaald in een herinzaaifrequentie en vervolgens in normbedragen voor de kosten van extra herinzaai. De relatie tussen de berekende opbrengstdepressie en het aandeel herinzaai staat in Figuur 6.1 .

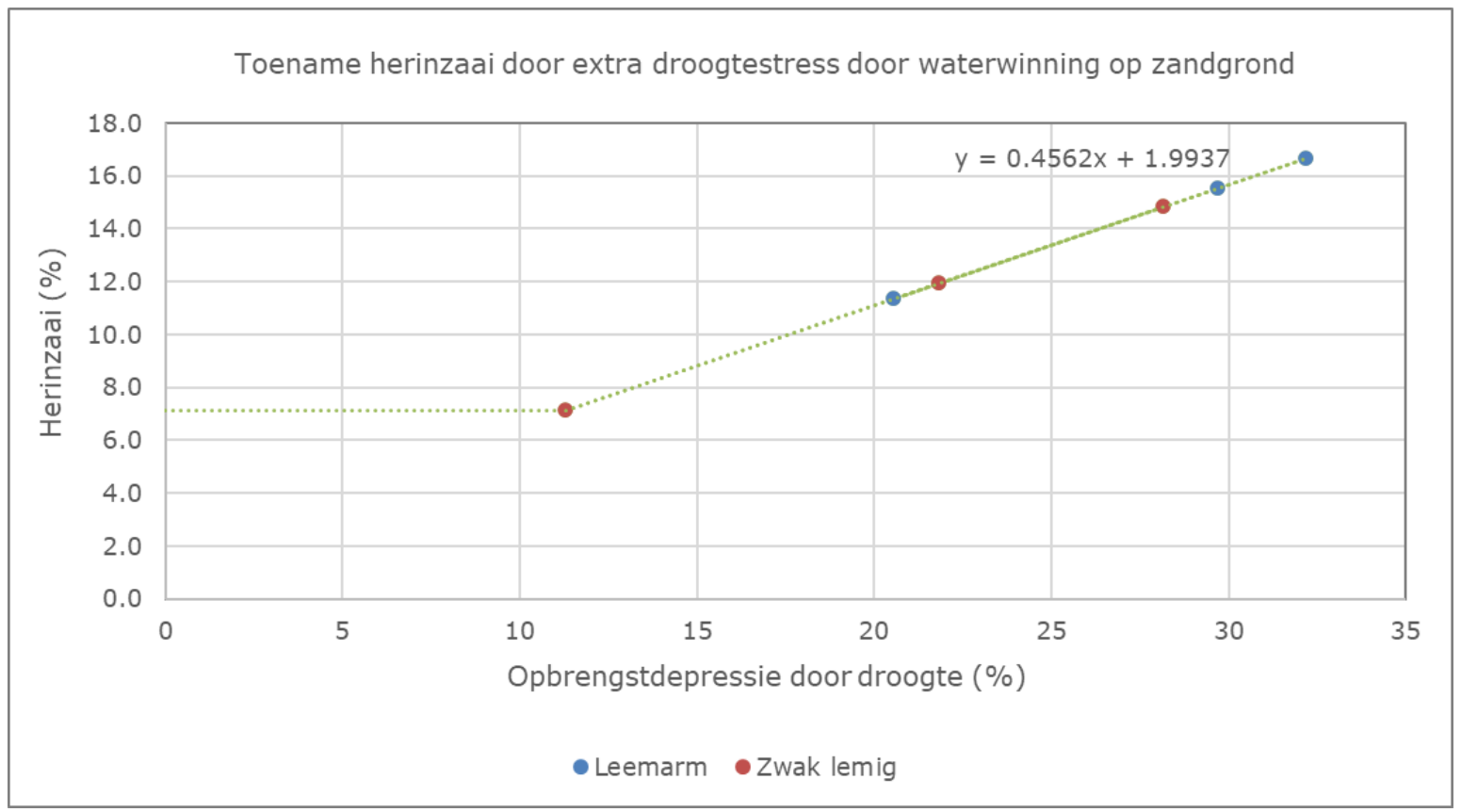

Figuur 6.1 Herinzaaifrequentie (\%) in relatie tot de opbrengstdepressie (vermindering bruto grasproductie) door extra droogtestress door waterwinning op droge zandgrond.

De gemiddelde bruto grasopbrengsten uit de modelberekeningen zijn gecorrigeerd voor het aandeel herinzaai om het effect op opbrengst en de kosten te kunnen berekenen. Volgens de Herinzaaiwijzer systematiek is per variant (grondsoort $x$ wateronttrekking) de gemiddelde bruto en netto grasopbrengst berekend voor een herinzaaifrequentie van eens in de 14 jaar conform de referentiesituatie (Zwak lemig, droogtevariant Referentie) en een hogere herinzaaifrequentie door extra droogte (Zwak lemig en Leemarm, Waterwinning 1 en 2). Daarbij is rekening gehouden met opbrengstverlies in het jaar van herinzaai, verlies van productie door stikstofverlies en een productiepiek in het eerste jaar volledige productiejaar (paragraaf 3.6).

Uitgegaan is van herinzaai in het najaar, waarbij de productie in het jaar van herinzaai $25 \%$ van de jaaropbrengst van het laatste jaar uit de herinzaaicyclus bedraagt. Op droge zandgronden wordt bij voorkeur in het najaar ingezaaid, omdat het risico op mislukken van herinzaai door droge omstandigheden in het voorjaar relatief groot is.

De bruto grasopbrengst is omgerekend in een netto grasopbrengst aan de hand van de voederwaardekenmerken voor de energiehoeveelheid en het eiwitgehalte en het aandeel maaien en weiden. De voederwaarde van voedermiddelen voor melkvee wordt voor energie uitgedrukt in VoederEenheidMelk (VEM) en eiwit in Darm Verteerbaar Eiwit (DVE). Deze twee kenmerken zijn bepalend voor de vertaling naar 
de financiële waarde. Verondersteld is dat de voederwaarde en het rendement voor weiden en maaien lineair afnam van jaar 1 tot de lange(re) termijn, die op 30 jaar is gesteld.

Voor het bepalen van normbedragen voor extra herinzaai afhankelijk van opbrengstdepressie is onderscheid gemaakt in de opbrengstverandering door extra droogte en de opbrengstverandering door extra herinzaai. Hiertoe zijn volgens de HerinzaaiWijzer-methodiek per variant voor de volgende twee situaties de bruto en netto grasopbrengsten berekend:

1. Grasopbrengstverloop herinzaaifrequentie van eens in de 14 jaar (uitgangssituatie)

- $\quad$ Per variant is de gemiddelde opbrengst berekend voor een herinzaaifrequentie van eens in de 14 jaar, conform de referentiesituatie met de laagste opbrengstdepressie (Zwak lemig, droogtevariant Referentie).

- Daarbij is de gemiddelde drogestofopbrengst over een periode van 14 jaar gelijk gesteld aan de gemiddelde berekende opbrengst uit de bedrijfsberekening.

- In Bijlage 5 staan per variant de gebruikte uitgangspunten. In Bijlage 6 staat het opbrengstverloop over de jaren per bodemtype en droogtevariant.

2. Grasopbrengstverloop bij verhoogde herzaaifrequentie door extra droogte

- $\quad$ Per variant is voor een verhoogde herinzaaifrequentie als gevolg van extra droogte een versnelde achteruitgang van de graszode gesimuleerd door te kalibreren met de 'degeneratiefactor lange termijn'. Hiermee is er voor gezorgd dat in het laatste jaar van de herinzaaicyclus het opbrengstniveau van jaar 14 uit de referentiesituatie werd bereikt.

- $\quad$ Ook is de degeneratie van de voederwaarde en het rendement voor weiden en maaien voor de verkorte herinzaaiperiode gelijk gesteld aan de uitgangssituatie door te kalibreren met de betreffende rendementen op lange termijn (jaar 30).

- In Bijlage 7 staan de invoerwaarden voor de betreffende varianten. In Bijlage 8 staat per bodemtype en droogtevariant het grasopbrengstverloop bij een hogere herinzaaifrequentie.

De opbrengstverandering als gevolg van extra herinzaai is het verschil tussen de gemiddelde grasopbrengst per jaar bij een herinzaaifrequentie van eens in de 14 jaar en bij een hogere herinzaaifrequentie door extra droogte.

De resultaten voor de gemiddelde bruto en grasgrasopbrengst staan respectievelijk in Tabel 14 en 15 .

Tabel 14 Bruto grasopbrengst per bodemtype per droogtevariant gesimuleerd voor melkveeproefbedrijf De Marke voor een referentiesituatie waarbij de herinzaaifrequentie eens in de 14 jaar bedraagt, een verkorte herinzaaiperiode door extra droogte (Herinzaai < 14 jaar), (Herinzaai < 14 jaar) en het verschil tussen deze twee situaties.

\begin{tabular}{|c|c|c|c|c|c|}
\hline \multirow[t]{2}{*}{ Variant } & \multirow{2}{*}{$\begin{array}{c}\text { Opbrengst- } \\
\text { depressie } \\
(\%)\end{array}$} & \multirow{2}{*}{$\begin{array}{c}\text { Herinzaai- } \\
\text { periode } \\
\text { (\#jaar) }\end{array}$} & \multicolumn{3}{|c|}{ Bruto grasopbrengst (kg.ha-1) } \\
\hline & & & $\begin{array}{c}\text { Herinzaai } \\
14 \text { jaar }\end{array}$ & $\begin{array}{l}\text { Herinzaai } \\
<14 \text { jaar }\end{array}$ & Verschil \\
\hline \multicolumn{6}{|l|}{ Zwak lemig } \\
\hline Referentie & 11,3 & 14 & 10065 & 10065 & 0 \\
\hline Waterwinning 1 & 21,8 & 9 & 8871 & 8776 & 95 \\
\hline Waterwinning 2 & 28,1 & 7 & 8154 & 7824 & 330 \\
\hline \multicolumn{6}{|l|}{ Leemarm } \\
\hline Referentie & 20,5 & 9 & 9016 & 8769 & 247 \\
\hline Waterwinning 1 & 29,7 & 7 & 7983 & 7653 & 330 \\
\hline Waterwinning 2 & 32,2 & 6 & 7701 & 7306 & 396 \\
\hline
\end{tabular}


De bruto grasopbrengst nam vooral af door een toename van het stikstofverlies per jaar als gevolge van frequenter herinzaaien en relatief beperkt door een veranderd productieverloop. Het betrof dezelfde hoeveelheid stikstofverlies, maar het was verdeeld over minder jaren.

De bruto grasopbrengsten voor beide herinzaaifrequenties per variant zijn omgerekend naar een netto grasopbrengst voor KVEM en KDVE door de bruto grasopbrengst te vermenigvuldigen met de VEM- en DVEgehalten. De netto grasopbrengsten voor de referentiesituatie en een verkorte herinzaaiperiode door extra droogte staan in Tabel 15.

Tabel 15 Netto grasopbrengst per bodemtype per droogtevariant gesimuleerd voor melkveeproefbedrijf De Marke voor de referentiesituatie waarbij de herinzaaifrequentie eens in de 14 jaar bedraagt, een verkorte herinzaaiperiode door extra droogte (Herinzaai < 14 jaar), (Herinzaai < 14 jaar) en het verschil tussen deze twee situaties.

\begin{tabular}{lcccc}
\hline Variant & \multicolumn{2}{c}{ Netto KVEM-opbrengst } & \multicolumn{2}{c}{ Netto KDVE-opbrengst } \\
\cline { 2 - 5 } & $\begin{array}{c}\text { Herinzaai } \\
\mathbf{1 4} \text { jaar }\end{array}$ & $\begin{array}{c}\text { Herinzaai } \\
<\mathbf{1 4} \text { jaar }\end{array}$ & $\begin{array}{c}\text { Herinzaai } \\
\mathbf{1 4} \text { jaar }\end{array}$ & $\begin{array}{c}\text { Herinzaai } \\
<\mathbf{1 4} \text { jaar }\end{array}$ \\
\hline Zwak lemig & & & & 808 \\
\hline Referentie & 7939 & 7939 & 808 & 708 \\
\hline Waterwinning 1 & 6986 & 6951 & 711 & 648 \\
\hline Waterwinning 2 & 6412 & 6359 & 653 & 712 \\
\hline Leemarm & & & 723 & 627 \\
\hline Referentie & 7104 & 6997 & 639 & 602 \\
\hline Waterwinning 1 & 6277 & 6159 & 616 & \\
\hline Waterwinning 2 & 6052 & 5913 & & \\
\hline
\end{tabular}

De afname van de bruto grasopbrengst werkte door in een afname van de netto KVEM- en KDVEgrasopbrengst. De afname van de netto grasopbrengst kwam tot uiting in de kosten van extra herinzaai (zie volgende paragraaf).

\subsection{Kosten/baten extra herinzaai}

De financiële waarde van de netto grasopbrengst is berekend door de netto opbrengst te vermenigvuldigen met de voerprijzen voor VEM en DVE van respectievelijk 17 eurocent per kVEM en 97 eurocent per kDVE. De gemiddelde kosten voor herinzaai per ha per jaar zijn eveneens berekend. Voor herinzaai zijn geen kosten voor doodspuiten met glyfosaat en bestrijding van onkruid meegenomen, aangezien deze middelen in waterwingebieden niet zijn toegestaan. Ook zijn geen kosten voor extra bemesting en kilveren meegenomen, aangezien deze kosten van toepassing zijn bij het verbeteren van de maaiveldligging. De totale kosten voor standaard herinzaai komen daarmee op 610 euro per ha. De voerprijzen en de kosten voor herinzaai zijn gebaseerd op prijzen en tarieven uit de KWIN-veehouderij (2021-2022).

In Bijlage 9 staat een uitsplitsing van de kosten voor herinzaai. In Tabel 16 staat het verschil in waarde van de netto grasopbrengst tussen de referentie met herinzaai eens in de 14 jaar, de frequentere herinzaai door extra droogtedepressie en het verschil tussen deze twee situaties. 
Tabel 16 Waarde netto grasopbrengst per bodemtype per droogtevariant gesimuleerd voor melkveeproefbedrijf De Marke voor de referentiesituatie waarbij de herinzaaifrequentie eens in de 14 jaar bedraagt (Herinzaai 14 jaar), een verkorte herinzaaiperiode door extra droogte (Herinzaai $<14$ jaar) en het verschil tussen deze twee situaties.

\begin{tabular}{|c|c|c|c|c|c|}
\hline \multirow[t]{2}{*}{ Variant } & \multirow{2}{*}{$\begin{array}{c}\text { Opbrengst- } \\
\text { depressie } \\
(\%)\end{array}$} & \multirow{2}{*}{$\begin{array}{c}\text { Herinzaai- } \\
\text { periode } \\
(\# \text { jaar) }\end{array}$} & \multicolumn{3}{|c|}{ Waarde netto grasopbrengst (euro.ha ${ }^{-1}$.jaar $^{-1}$ ) } \\
\hline & & & $\begin{array}{c}\text { Herinzaai } \\
14 \text { jaar }\end{array}$ & $\begin{array}{l}\text { Herinzaai } \\
<14 \text { jaar }\end{array}$ & Verschil \\
\hline \multicolumn{6}{|l|}{ Zwak lemig } \\
\hline Referentie & 11,3 & 14 & 2134 & 2134 & 0 \\
\hline Waterwinning 1 & 21,8 & 9 & 1878 & 1868 & 10 \\
\hline Waterwinning 2 & 28,1 & 7 & 1723 & 1709 & 14 \\
\hline \multicolumn{6}{|l|}{ Leemarm } \\
\hline Referentie & 20,5 & 9 & 1909 & 1880 & 29 \\
\hline Waterwinning 1 & 29,7 & 7 & 1687 & 1655 & 32 \\
\hline Waterwinning 2 & 32,2 & 6 & 1627 & 1589 & 37 \\
\hline
\end{tabular}

In Tabel 17 staan de kosten per bodemtype en droogtevariant en de kosten afhankelijk van de opbrengstdepressie bestaande uit de kosten voor herinzaai, de waardevermindering van de netto grasopbrengst en de som hiervan. De totale kosten betreft de normbedragen voor extra herinzaai.

Tabel 17 Normbedragen extra herinzaai door waterwinning voor een relatief droge zandgrond in relatie tot opbrengstdepressie bestaande uit de directe kosten voor herinzaai en de gemiddelde waardevermindering van de netto grasopbrengst.

\begin{tabular}{|c|c|c|c|c|c|c|}
\hline \multirow[t]{2}{*}{ Variant } & \multirow{2}{*}{$\begin{array}{c}\text { Opbrengst- } \\
\text { depressie } \\
(\%)\end{array}$} & \multirow{2}{*}{$\begin{array}{c}\text { Herinzaai- } \\
\text { periode } \\
\text { (\#jaar) }\end{array}$} & \multirow{2}{*}{$\begin{array}{c}\text { Kosten } \\
\text { herzaai } \\
\text { (euro) }\end{array}$} & \multicolumn{3}{|c|}{$\begin{array}{c}\text { Kosten in relatie tot opbrengstdepressie } \\
\left(\text { euro. } \mathrm{ha}^{-1} \text {.jaar } \mathrm{jar}^{-1}\right)\end{array}$} \\
\hline & & & & Herinzaai & Grasopbrengst & Normbedrag \\
\hline \multicolumn{7}{|l|}{ Zwak lemig } \\
\hline Referentie & 11,3 & 14 & 44 & 0 & 0 & 0 \\
\hline Waterwinning 1 & 21,8 & 9 & 68 & 24 & 10 & 34 \\
\hline Waterwinning 2 & 28,1 & 7 & 87 & 44 & 14 & 58 \\
\hline \multicolumn{7}{|l|}{ Leemarm } \\
\hline Referentie & 20,5 & 9 & 68 & 24 & 29 & 53 \\
\hline Waterwinning 1 & 29,7 & 7 & 87 & 44 & 32 & 75 \\
\hline Waterwinning 2 & 32,2 & 6 & 102 & 58 & 37 & 95 \\
\hline
\end{tabular}

De kosten voor extra herinzaai in relatie tot de opbrengstdepressie uit Tabel 17 staan eveneens in Figuur 6.2. Met trendlijnen zijn de relaties tussen de opbrengstdepressie en de kosten weergegeven. 


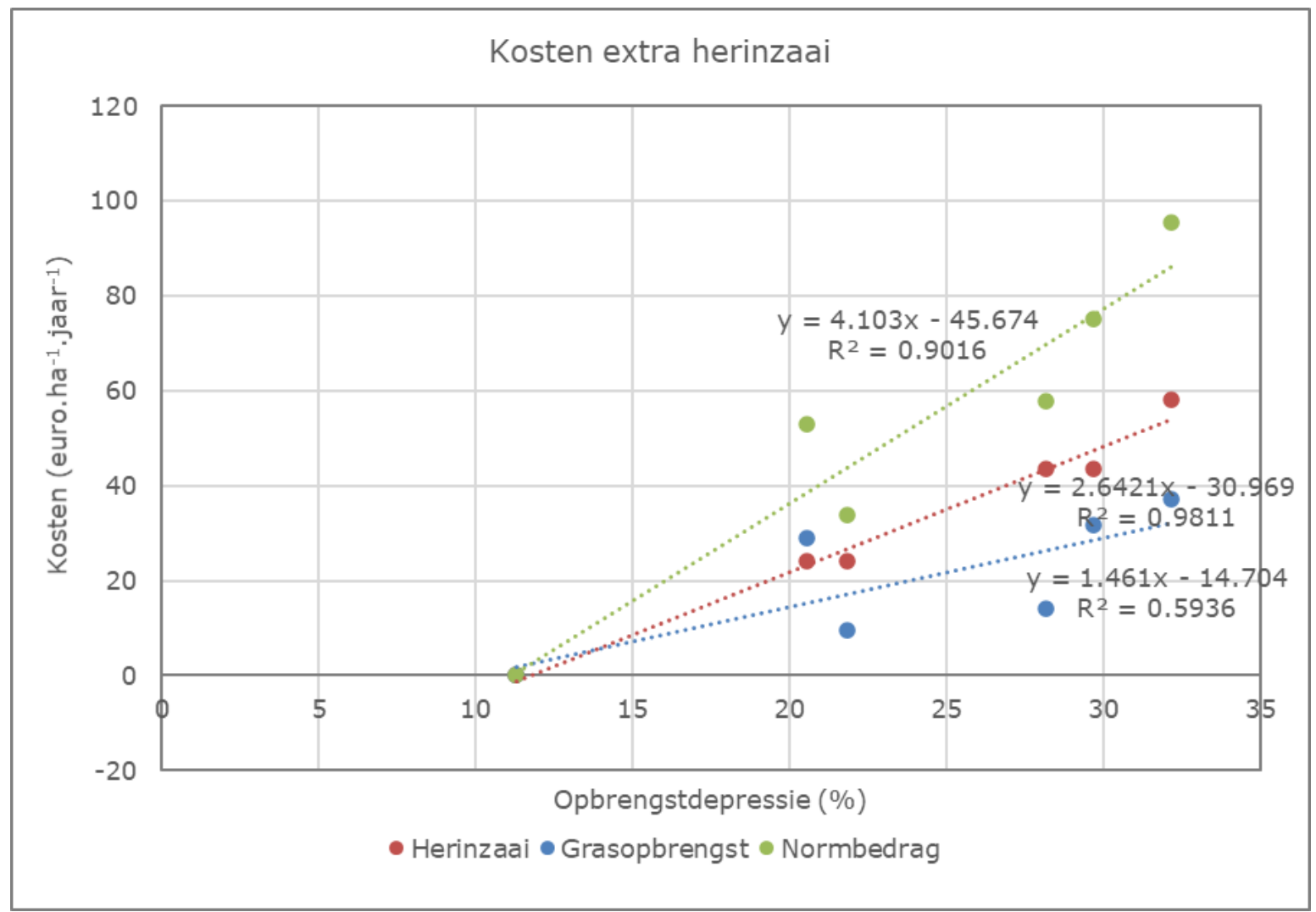

Figuur 6.2 Kosten extra herinzaai (euro.ha-1.jaar-1) door waterwinning op een relatief droge zandgrond in relatie tot de opbrengstdepressie voor grasland, met onderscheid tussen de directe kosten voor herinzaai, het waardeverlies van de netto grasopbrengst en de normbedragen als totaal hiervan. Voor de normbedragen staat de functie vermeld.

De directe herinzaaikosten en de kosten voor het verlies aan netto grasproductie stegen evenredig met de opbrengstdepressie. De stijging van de totale kosten (normbedragen) liet zodoende eveneens een lineair verband zien.

Per procent opbrengstschade bedragen de kosten voor extra herinzaai door waterwinning $€ 4,1$ per ha per jaar, gegeven de gehanteerde tarieven. Daarvan bedragen de kosten voor herinzaai $€ 2,64$ en het verlies aan grasproductie $€ 1,46$ per ha per jaar. 


\section{$7 \quad$ Discussie}

\subsection{Persistentie Engels raai}

Engels raaigras is een grassoort die droogtegevoelig is, waardoor de grasgroei vermindert bij een neerslagtekort, spruiten afsterven bij doorzettende droogte en uiteindelijk hele planten dood kunnen gaan bij extreem aanhoudende droogte zoals dat in het bijzonder in 1976 en 2018 het geval was. Engels raaigras heeft echter ook een groot herstellingsvermogen. Vanuit de overgebleven planten kan de zode zich herstellen. Hiertoe moet minimaal één levende spruit per $\mathrm{dm}^{2}$ aanwezig zijn.

De resultaten van de rassenproeven laten zien dat er een relatie is tussen de aanvankelijke grasbezetting en de teruglopende grasbezetting als gevolg van droogte. De vastgestelde vermindering van de bezetting is echter niet alleen een gevolg van vochttekort maar ook van hoge temperaturen die vaak gepaard gaan met droogte. Doordat vochttekort en hittestress tegelijkertijd kunnen optreden zijn beide effecten niet apart te kwantificeren. Bij een goede grasbezetting en een vrijwel gesloten zode is de schade aan de grasmat door droogte en hitte geringer. Als de zode echter al open is wordt de kans op schade groter. Dit effect werd in de CGO-rassenproeven aangetoond en is rasgebonden en is niet alleen een gevolg van droogte maar ook van het beter bestand zijn tegen gebruik in de vorm van betreding en berijding.

In het CGO-onderzoek wordt de bezetting van grasrassen geschat op basis van een visuele waarneming. Het betreft dus geen exacte meting en is zodoende afhankelijk van de persoon die dit uitvoert. Verder zijn enkele proeflocaties op zandgrond beperkt beregend geweest. Exacte gegevens hiervan zijn niet bekend. De vastgestelde achteruitgang van de bezetting van Engels raaigras in 2018-2019 als gevolg van droogte kan hierdoor onderschat zijn.

\subsection{Resultaten modelberekeningen}

De gegeven GLG en GHG uit Tabel 3 zijn dermate laag dat sprake lijkt te zijn van hangwaterprofielen en dat impliceert dat droogteschade niet zou afhangen van een (toename van) een grondwateronttrekking. De simulaties met Waterpas voor de situatie met verlaagde GLG en GHG volgens Tabel 4, gaven echter aan dat de droogteschade wel toenam (Tabel 13). De hoogte van het grondwater zat daarbij blijkbaar op een kantelpunt waarbij in de referentiesituatie nog wel vochtlevering uit de ondergrond plaatsvond en dit bij grondwaterontrekking minder (middel-droog) of nauwelijks meer het geval was (zeer droog). Daarmee representeert het onderzoek situaties van waterwinning op droge zandgrond, waarbij extra droogteschade door grondwateronttrekking optreedt en ervaren wordt.

Opviel dat de GHG en de GLG die volgden uit de modelfit van het stijghoogteverloop voor peilbuis B34C0150_1 relatief laat bereikt werden, respectievelijk half april en half oktober voor de GHG en GLG. Dit kwam doordat de stijghoogte die als onderrand is gekozen piekte op 11 maart. Op dergelijke zandgronden wordt doorgaans de GHG en GLG minimaal een maand eerder bereikt dan met Waterpas is berekend (Dam en Gooren, 2021). Op basis van deze constatering zijn de hydrologische en bedrijfstechnische berekeningen nogmaals uitgevoerd, om te zien wat het effect is van een vervroeging van de GLG en GHG. De sinus van de stijghoogte die als onderrand is gekozen is gefit op de jaren 2009-2016 uit de studie van Arcadis, met een verschuiving van de piek met 30 dagen eerder in het jaar (dag 92). In Figuur 7.1 staat een vergelijk tussen de basissituatie (rode lijn) en de nieuwe fit (groene lijn). 


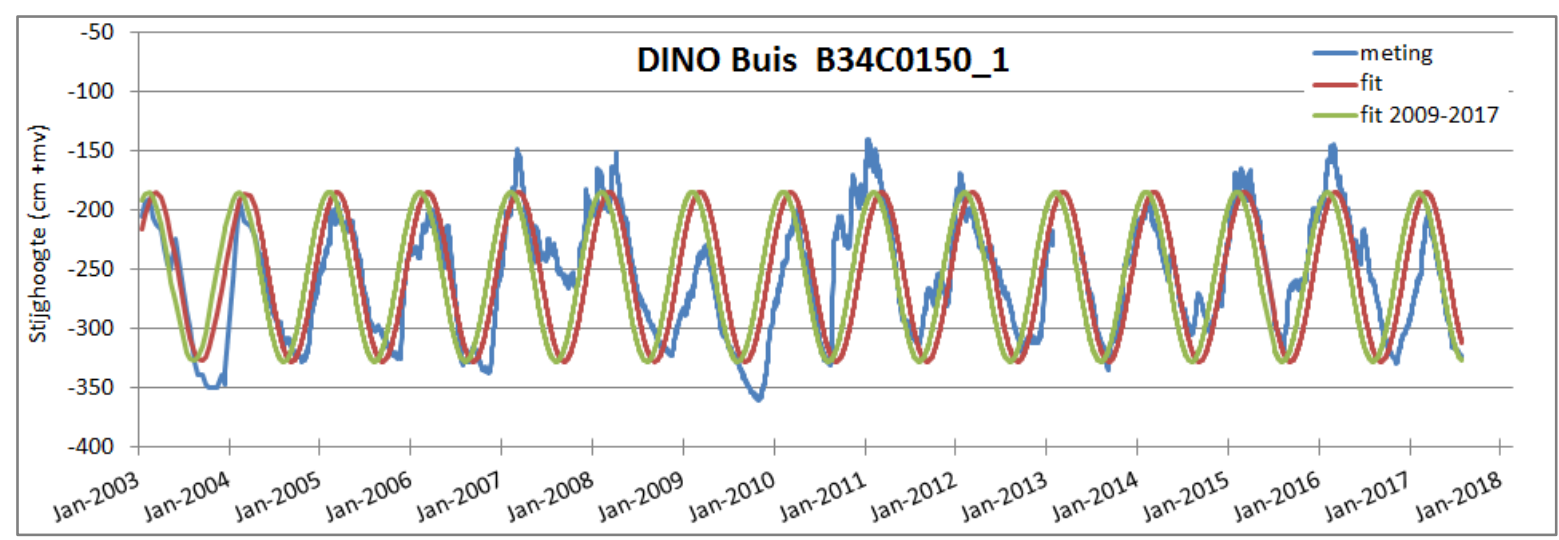

Figuur 7.1 Resultaten van het vervroegen (30 dagen) van de fit van het stijghoogteverloop (groene lijn) met een sinus door de gemeten waarden van peilbuis B34C0150_1. Gemeten waarden van het DINOloket.

Het berekende gemiddelde grondwaterstandsverloop van de twintig weerjaren (2000-2019) op basis van de nieuwe fit met een vervroeging van 30 dagen staat in Figuur 7.2. Het betreft hierbij de grondwaterstanden in de periode van 1 januari tot en met 31 december.

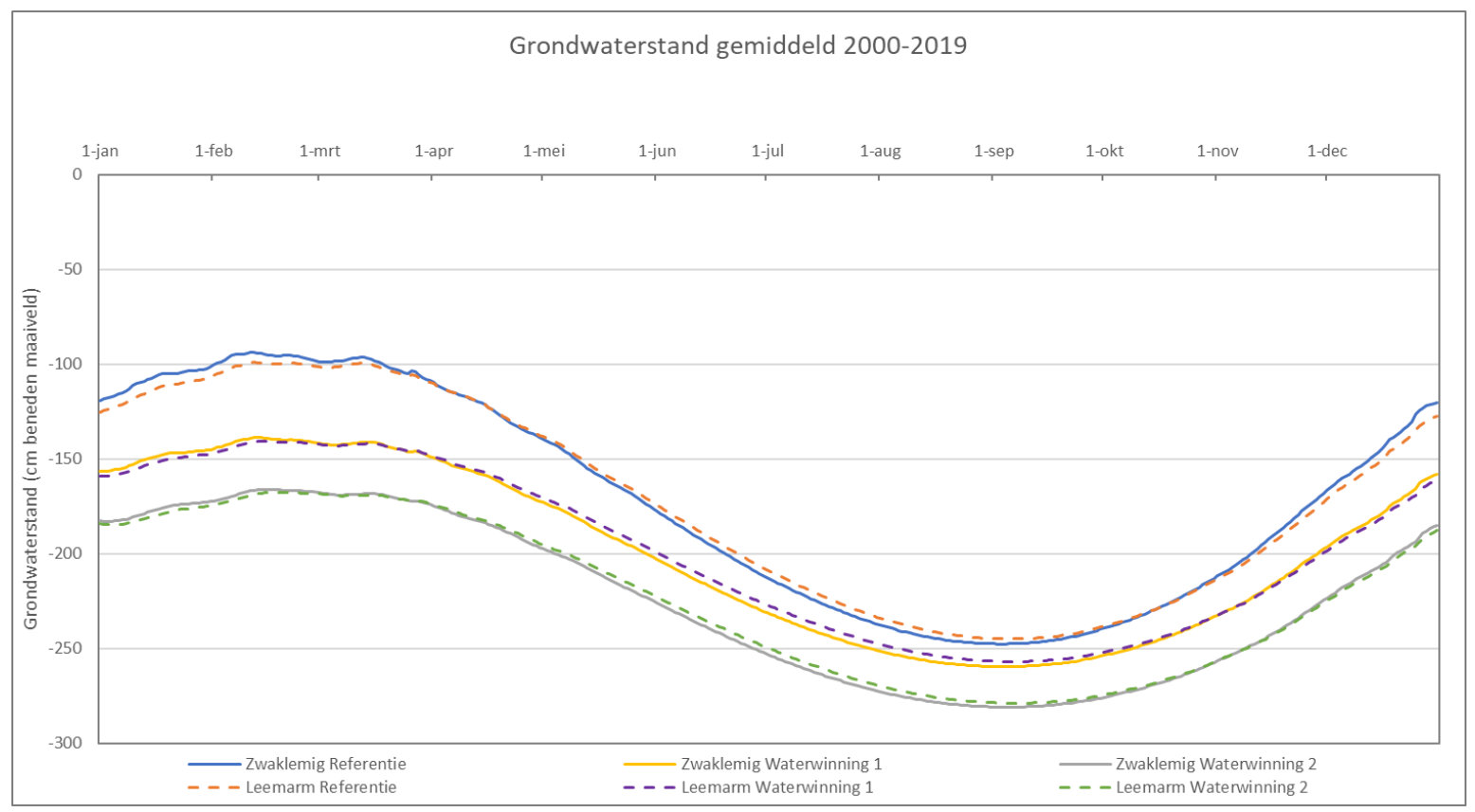

Figuur 7.1 Gesimuleerde grondwaterstand van 1 januari tot en met 31 december bij een vervroegde GHG en GLG gemiddeld over de reeks van weerjaren 2000-2019 voor de bodemtypen Leemarm en Zwak lemig fijn zand en de droogtevarianten Referentie, Waterwinning 1 en Waterwinning 2 voor melkveeproefbedrijf De Marke.

Met de vervroegde fit werden de GHG en GLG ongeveer anderhalve maand eerder bereikt, namelijk respectievelijk eind februari en begin september.

In de modelberekeningen is uitsluitend het effect van vochttekort door droogte op de grasopbrengst gesimuleerd en niet het effect van hittestress. Droogte brengt hittestress teweeg doordat planten onvoldoende water kunnen verdampen voor verkoeling, waardoor bladverbranding gaat optreden. Door hittestress gaat het functioneren van een plant snel achteruit (fotosynthese, vocht- en nutriëntenopname) en sterven bladeren af waardoor de biomassa vermindert in plaats van toeneemt.

De groei werd in het gebruikte groeimodel weliswaar gereduceerd door vochttekort en hoge temperaturen, maar de vermindering van biomassa door hittestress werd niet meegenomen, omdat hier geen gegevens van bekend zijn. De berekende biomassa is hierdoor mogelijk overschat. 
Om de orde van grootte van de berekende grasopbrengsten te beoordelen is een vergelijk gemaakt met grasopbrengsten van blijvend grasland van De Marke die zijn bepaald voor maaiomstandigheden (totale verse biomassa gewogen via een weegbrug en drogestof bepaald door vers grasmonsters achtereenvolgens te wegen, te drogen en terug te wegen) en afgeleid voor weiden aan de hand van grashoogtemetingen en terugrekening vanuit het totale rantsoen. In Figuur 7.1 staan de berekende en 'gemeten' grasopbrengsten gemiddeld over respectievelijk alle droogtevarianten (Leemarm en Zwak lemig) en alle percelen met verschillende bodemtextuur over de periode 2000-2019. De betreffende percelen op De Marke zijn in meer of mindere mate beregend.

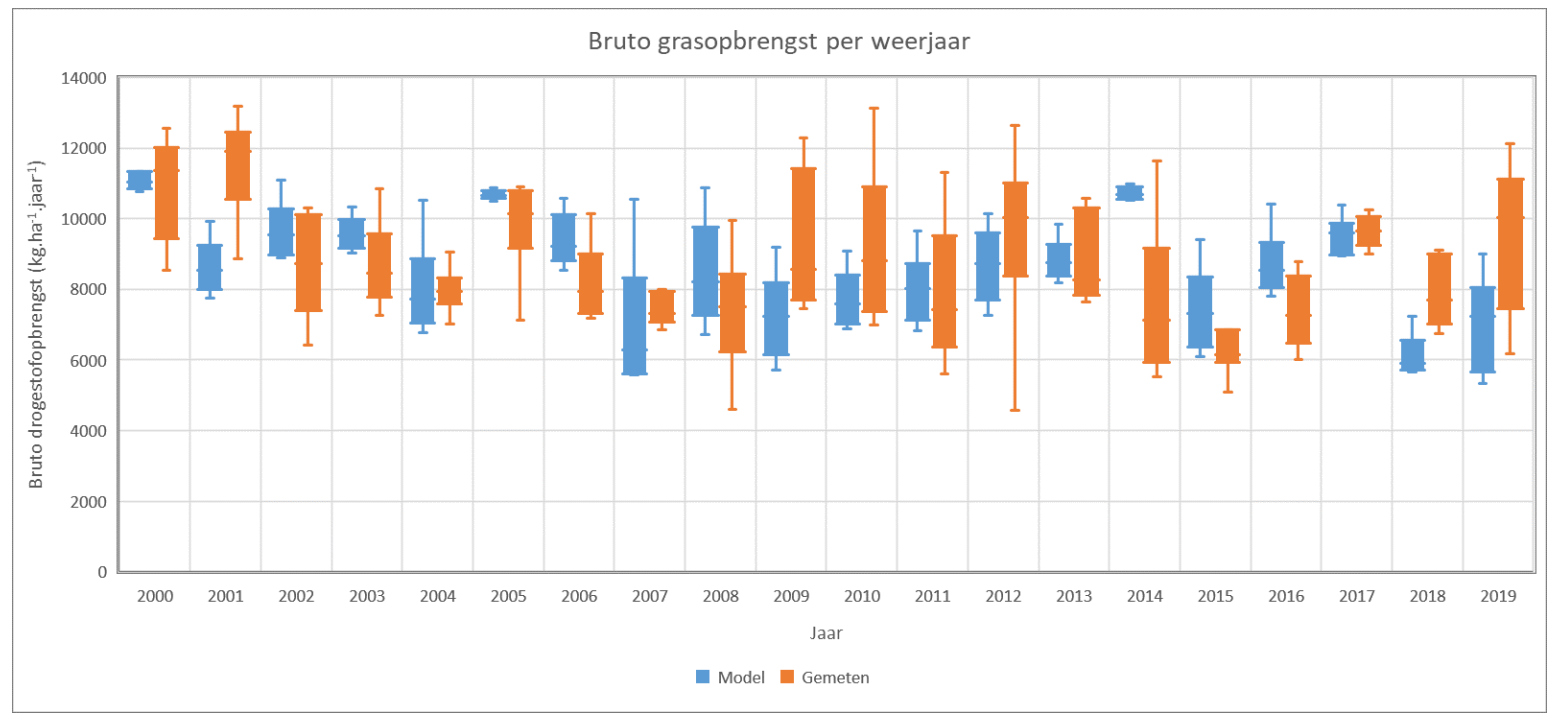

Figuur 7.1 Bruto drogestofopbrengst gras per ha per jaar berekend (weiden en maaien) en 'gemeten' (bepaald voor maaien en afgeleid voor weiden) grasopbrengst voor De Marke (2000-2019). De weergegeven kaders en lijnen betreffen de verdeling van resultaten in kwartielen, met de mediaan en de uitschieters. De verticale lijnen geven variabiliteit buiten het bovenste en onderste kwartiel aan en punten buiten die lijnen betreffen sterk afwijkende waarden.

De 'gemeten' grasopbrengsten op De Marke waren voor een aantal jaren gemiddeld lager (2002, 2003, 2005, 2006, 2008, 2011, 2014-2016), ongeveer gelijk (2000, 2004, 2013, 2017) en hoger (2001, 2007, $2009,2010,2012,2018,2019)$. Daarbij was de variatie van de 'gemeten' grasopbrengsten groter dan de variatie tussen de uitkomsten van de berekende droogtevarianten.

De volgende factoren kunnen afwijkingen verklaren:

- De 'gemeten' grasopbrengsten zijn bepaald voor maaien (wegen en droge stofbepaling) en afgeleid voor weiden op basis van grashoogtemetingen en geschatte grasopname.

- In de berekeningen is geen beregening toegepast terwijl dat bij de gemeten opbrengsten wel het geval was. Verondersteld zou kunnen worden dat hierdoor de berekende opbrengsten structureel lager uit zouden komen, echter dit was niet het geval. Beregening geeft weliswaar voor de betreffende snede een opbrengstverhoging, maar bij gelijkblijvende bemesting wordt de opbrengstverhoging in latere sneden in meer of mindere mate gecompenseerd door hogere opbrengsten zonder beregening (Hoving en Van Riel, 2001). In de betreffende veldproef was het verschil groter naarmate de droogte langer aanhield, waardoor uiteindelijk de opbrengstverhoging door beregening op jaarbasis beperkt was. In de droge jaren 2018 en 2019 was sprake van langdurige droogte en het is waarschijnlijk dat beregening in deze jaren de opbrengst substantieel verhoogd heeft.

- Op De Marke vindt door relatief droge omstandigheden vaker herinzaai plaats dan eens in de 14 jaar, zoals dat in de berekeningen als referentie is bepaald. Door extra herinzaai bleek vooral het verlies van stikstof de bruto grasopbrengst te verminderen en dit kan een verklaring zijn voor de jaren waarbij de opbrengsten uit de bedrijfsberekeningen hoger waren dan de praktijk.

- Voor het stikstofleverend vermogen van de bodem (NLV) is in de berekeningen $140 \mathrm{~kg} \mathrm{~N}$ per ha per jaar aangehouden, maar deze is van perceel tot perceel verschillend. Ook kan de werkelijke $\mathrm{N}$ levering aanzienlijk afwijken van het vastgestelde NLV. Bovendien wordt in de berekeningen het NLV 
niet gereduceerd door droogte, terwijl dit in de werkelijkheid wel het geval kan zijn. Wel vond een correctie voor droogte in een snede achteraf plaats, omdat door een lagere groei minder stikstof opgenomen wordt, waardoor de opgegeven NLV niet gehaald wordt.

- De neerslaghoeveelheden van het gebruikte neerslagstation Hengelo ( $g$ ld) en de neerslagmetingen op De Marke konden afwijken.

- Het beweidingsregime in de berekeningen en in de werkelijkheid komen niet precies overeen.

Het verhoogde maaipercentage in de berekeningen door extra droogte wordt verklaard doordat na een droge periode opnieuw groeitrappen aangelegd moeten worden om voldoende weideaanbod te creëren voor het weiden van melkvee.

\subsection{Normbedragen herinzaai}

De normbedragen zijn tot stand gekomen door een rekenkundige benadering van de verandering in grasproductie en een toename van kosten voor herinzaai. Extra herinzaai kost echter ook extra arbeid in de vorm van het regelen en voorbereiden van herinzaai en bestaat het risico op het mislukken van herinzaai, waardoor het werkelijke productieverlies en de kosten hoger kunnen zijn dan berekend.

Extra droogte door grondwaterwinning vergroot niet alleen de kosten voor herinzaai, maar geeft ook een verhoging van bedrijfskosten door verlies aan grasproductie. Het berekenen van deze kosten viel echter buiten het kader van de vraagstelling en is zodoende buiten beschouwing gebleven.

Op basis van de vervroegde fit en als gevolg daarvan een vervroeging van GHG en GLG, zoals die in paragraaf 7.2 staat beschreven, is conform paragraaf 6.2 de financiële waarde van de netto grasopbrengst berekend, evenals de gemiddelde kosten voor herinzaai per ha per jaar. Deze berekening kan als een gevoeligheidsanalyse beschouwd worden van de resultaten die in paragraaf 6.2 beschreven staan.

In Tabel 18 staan de kosten per bodemtype en droogtevariant en de kosten afhankelijk van de opbrengstdepressie bestaande uit de kosten voor herinzaai, de waardevermindering van de netto grasopbrengst en de som hiervan. De totale kosten betreft de normbedragen voor extra herinzaai. De normbedragen zijn vrijwel gelijk aan die in de basissituatie zoals die in Tabel 17 staan (paragraaf 6.2).

Tabel 18 Normbedragen extra herinzaai door waterwinning voor een relatief droge zandgrond in relatie tot opbrengstdepressie bestaande uit de directe kosten voor herinzaai en de gemiddelde waardevermindering van de netto grasopbrengst bij een vervroeging van de GHG en GLG van ongeveer anderhalve maand (respectievelijk eind februari en begin september).

\begin{tabular}{|c|c|c|c|c|c|c|}
\hline \multirow[t]{2}{*}{ Variant } & \multirow{2}{*}{$\begin{array}{c}\text { Opbrengst- } \\
\text { depressie } \\
(\%)\end{array}$} & \multirow{2}{*}{$\begin{array}{c}\text { Herinzaai- } \\
\text { periode } \\
\text { (\#jaar) }\end{array}$} & \multirow{2}{*}{$\begin{array}{c}\text { Kosten } \\
\text { herzaai } \\
\text { (euro) }\end{array}$} & \multicolumn{3}{|c|}{$\begin{array}{c}\text { Kosten in relatie tot opbrengstdepressie } \\
\left(\text { euro.ha- } \text {.jaar }^{-1}\right)\end{array}$} \\
\hline & & & & Herinzaai & Grasopbrengst & Normbedrag \\
\hline \multicolumn{7}{|l|}{ Zwak lemig } \\
\hline Referentie & 15.2 & 14 & 44 & 0 & 0 & 0 \\
\hline Waterwinning 1 & 21.2 & 10 & 61 & 17 & 15 & 32 \\
\hline Waterwinning 2 & 27.1 & 7 & 87 & 44 & 14 & 58 \\
\hline \multicolumn{7}{|l|}{ Leemarm } \\
\hline Referentie & 21.9 & 9 & 68 & 24 & 29 & 53 \\
\hline Waterwinning 1 & 27.8 & 7 & 87 & 44 & 32 & 75 \\
\hline Waterwinning 2 & 31.1 & 6 & 102 & 58 & 37 & 95 \\
\hline
\end{tabular}

De kosten voor extra herinzaai in relatie tot de opbrengstdepressie uit Tabel 18 staan eveneens in Bijlage 10 Figuur B10.1. Met trendlijnen zijn de relaties tussen de opbrengstdepressie en de kosten weergegeven. De normbedragen zijn vergelijkbaar met die uit de basisberekening zoals die paragraaf 6.2 staan. Evenals in paragraaf 6.2 stegen de directe herinzaaikosten en de kosten voor het verlies aan netto grasproductie 
evenredig met de opbrengstdepressie, echter de relatie wijkt af van de relatie zoals die in Figuur 6.2 van paragraaf 6.2 staat. Dit komt omdat de bedragen bij andere opbrengstdepressies tot stand kwam. Het toepassen van de relaties levert zodoende verschillende bedragen op. Desalniettemin worden de relaties uit Figuur 2.6 als de uiteindelijke normbedragen beschouwd, aangezien deze het directe resultaat zijn van de basisberekeningen en de gekozen uitgangspunten (grondwatermodelberekeningen uitgevoerd door ARCADIS, 2019). 


\section{Conclusies}

- De standaard vermindering van de grasbezetting gedurende een lange periode volgens data van het CGO is als uitgangspunt genomen voor het vinden van een opbrengstdepressiepercentage waar beneden de frequentie voor herinzaai niet varieert (drempelwaarde).

- De drempelwaarde voor het herinzaaipercentage voor zandgrond bedroeg $7,1 \%$ (eens in de 14 jaar).

- De gevonden verminderde grasbezetting bij extreme droogte in 2018-2019 resulteerde in een herinzaaipercentage van $16,7 \%$ (eens in de 6 jaar).

- De berekende varianten met het Waterpasinstrumentarium voor twee typen zandgrond en drie verschillende gradaties van droogtestress (2000-2019), resulteerde in een opbrengstdepressie van $11,3 \%$ voor de minst droogtegevoelige situatie en $32,2 \%$ voor de meest droogtegevoelige situatie bij waterwinning.

- De laagst berekende opbrengstdepressie van $11,3 \%$ (of minder) is gerelateerd aan het herinzaaipercentage $7,1 \%$. Dit betekent, dat zolang dit opbrengstdepressiepercentage niet wordt overschreden, herinzaai eens in de 14 jaar plaatsvindt.

- De hoogst berekende opbrengstdepressie van $32,2 \%$ is gerelateerd aan het herinzaaipercentage $16,7 \%$. Door middel van interpolatie van de opbrengstreductiepercentages zijn de herinzaaifrequenties voor de overige varianten berekend.

- Op basis van deze herinzaaifrequenties zijn de normbedragen berekend, welke bestaan uit de directe kosten voor herinzaai en een waardevermindering van de netto grasopbrengst gemiddeld over de herinzaaiperiode.

- Door frequenter herinzaaien nam de bruto grasopbrengst af, vooral door een groter stikstofverlies per jaar als het gevolg van het vrijkomen van stikstof door mineralisatie van de oude zode. Stikstof is naast vocht een belangrijke groeiparameter.

- Per procent opbrengstdepressie bedragen de kosten voor extra herinzaai door waterwinning $€ 4,1$ per ha per jaar, gegeven de gehanteerde tarieven.

- De modelberekeningen benaderden in grote lijn de orde van grootte van de gemeten grasopbrengsten op De Marke. Per weerjaar was de variatie tussen de gemeten opbrengsten groter dan de variatie tussen de berekende opbrengsten van de droogtevarianten. 


\section{Literatuur}

Alberda, T. (1970). The influence of carbohydrate reserves on respiration photosynthesis and dry matter production of intact plants. (Mededeling / Instituut voor Biologisch en scheikundig onderzoek van landbouwgewassen; No. no. 435).

Anonymus (2019). Aanbevelende Rassenlijst 2020. https://rassenlijst.info/ajax frontoffice/filemanager/files/wp-uploads/2020/01/AanbevelendeRassenlijst-Akkerbouw-en-Veehouderij-2020-def.pdf

ARCADIS, 2019. DRINKWATERWINNING 'T KLOOSTER. Verkennende modelstudie naar een klimaatrobuust grondwatersysteem. Conceptrapport 19 april 2019. Arcadis Nederland B.V.

Barker, D. J. (1985) 'The effects of summer moisture stress and its interaction with spring cutting managements on the production and persistence of a ryegrass (Lolium perenne L.) sward', Proceedings of the New Zealand Grassland Association, 46, pp. 237-238. Available at:

http://search.ebscohost.com.ezproxy.library. wur.nl/login. aspx?direct=true\&db=lah\&AN=19870799744\& site=ehost-live (Accessed: 19 May 2020).

Bartholomeus, R.P., Witte, J.P.M., van Bodegom, P.M., van Dam, J.C., de Becker, P., Aerts, R., 2012. Process-based proxy of oxygen stress surpasses indirect ones in predicting vegetation characteristics. Ecohydrology 5, 746-758. https://doi.org/10.1002/eco.261

Booysen, P.V. de and C. J. Nelson, 1975. Leaf Area and Carbohydrate Reserves in Regrowth of Tall Fescue. Crop Science Volume 15, Issue 2, Pages 262-266.

Blum, A. Crop responses to drought and the interpretation of adaptation. Plant Growth Regul 20, 135-148 (1996). https://doi.org/10.1007/BF00024010.

Cate, J.A.M., A.F. van Holst, H. Kleijer en J. Stolp, 1995. Handleiding bodemgeografisch onderzoek; richtlijnen en voorschriften. Deel B: Grondwater. Wageningen, DLO-Staring Centrum. Technisch Document 19B.

Ciais, Ph., M. Reichstein, R. Valentini, 2005. Europe-wide reduction in primary productivity caused by the heat and drought in 2003. Nature volume 437, pages529-533(2005).

Dam J.C. van en H.P.A. Gooren, 2021. Bodemvochtmetingen in zandgebieden van Hoog Nederland. Wageningen, WUR-SLM.

Dekkers, J.M J., 1992. De bodemgesteldheid van het proefbedrijf "Melkveehouderij en Milieu" te Hengelo (GId.). Resultaten van een bodemgeografisch onderzoek. DLO-Staring Centrum, Wageningen, Rapport 66.

Doorenbos, J. \& Kassam, A.H. 1979. Yield response to water. FAO Irrigation and Drainage Paper No. 33. Rome, FAO.

Deru J, Schilder H, van der Schoot RJ, van Eekeren N (2014) Genetic differences in root mass of Lolium perenne varieties under field conditions. Euphytica 199, 223-232. DOI 10.1007/s10681-014-1129-x

Feddes, R.A., P.J. Kowalik and H. Zaradny, 1978. Simulation of field water use and crop yield. Simulation Monographs. Pudoc. Wageningen. $189 \mathrm{pp}$.

Feddes R.A., Raats P.A.C. (2004) Parameterizing the soil-water-plant root system, in: R. A. Feddes, et al. (Eds.), Unsaturated-zone Modeling: Progress, Challenges, Applications Wageningen UR Frontis Series Wageningen. pp. 95-141.

Haan, M. de, Verloop, K, Hilhorst, G. (2019). Droogte op Koeien \& Kansen-bedrijven in 2018. Rapport nr.84

Hack-ten Broeke, M.J.D. and J.H.B.M. Hegmans, 1996. Use of soil physical characteristics from laboratory measurements or standard series for modelling unsaturated water flow. Agricultural Water Management 29 (1996): 201-213.

Holshof G. and A. van den Pol-van Dasselaar, 2014. Modelling DM growth of multi-species grassland plots in the Netherlands. Grassland Science in Europe, Vol. 19, 725-727.

Hoogerkamp, M., 1970. Verbetering van grasland? Landbouwmechanisatie 21: 749-758.

Hoving, I.E. en J.W. van Riel 2003. Het effect van diverse beregeningsstrategieën op de opbrengst van gras. In: Gebundelde verslagen van de Nederlandse vereniging voor weide- en voederbouw, 2002-2003, nr. 39.

Hoving, I.E. en G.L. Velthof, 2005. Landbouw- en milieukundige effecten van graslandvernieuwing op zanden kleigrond. Lelystad, Animal Sciences Group van WUR. PraktijkRapport Rundvee in voorbereiding. 
Hoving, I.E., 2006. De HerinzaaiWijzer als hulpmiddel bij afweging van graslandvernieuwing. Lelystad, Animal Sciences Group. PraktijkRapport Rundvee 82.

Hoving, I.E., J. van Riel, G. Holshof, M. Plomp, S. Agricola, K. van Boheemen en G. Roerink, 2019. Schatten van grasopbrengst op basis van spectrale reflectie, grashoogte en modellering; Onderzoeksresultaten van een maaiproef op zand- klei en veengrond 2016-2017. Wageningen Livestock Research, Report 1200.

Kamp, A. van der, J.A. de Boer, A.G. Evers, G. Holshof en R. Zom, 2003. Voedervoorziening in BBPR. Lelystad, Animal Sciences Group, intern rapport 496.

Korevaar, H., 1987. Productie en voederwaarde van gras bij gebruiks- en bemestingsbeperkingen voor natuurbeheer. Proefschrift. Proefstation voor de Rundveehouderij, Schapenhouderij en Paardenhouderij (PR), Lelystad. Rapport nr. 101

Kroes, J. G., J.C. van Dam, R.P. Bartholomeus, P. Groenendijk, M. Heinen, R.F.A. Hendriks, H.M. Mulder, I. Supit, P.E.V van Walsum, 2017. SWAP version 4: Theory description and user manual. Wageningen, Wageningen Environmental Research, Report 2780.

KWIN 2021-2022. Kwantitatieve Informatie Veehouderij. Handboek 31.

Lee, J. M. et al. (2017) 'Trajectory and causes of decline in the botanical composition of dairy-grazed pasture in the Waikato', Journal of New Zealand Grasslands, 79, pp. 89-95. Available at:

http://search.ebscohost.com.ezproxy.library. wur.nl/login. aspx?direct=true\&db=lah\&AN $=20183235592 \&$ s ite=ehost-live (Accessed: 19 May 2020).

Ludlow, M. M. (1989). "Strategies of response to water-stress," in Structural and Functional Responses to Environmental Stresses: Water Shortage, eds K. H. Kreeb, H. Richter, and T. M. Hinckley (The Hague: SPB Academic Publishing), 269-281.

Luten, W., Klooster, J.J., Roozeboom, L., 1974. Herinzaai van grasland. Verslag van een vergelijkend onderzoek met verschillende methoden van herinzaai in de periode 1971 t/m 1974. Rapport 39, Proefstation voor de Rundveehouderij, Lelystad: 26 pp.

Mandersloot, F., A.T.J. van Scheppingen en J.M.A. Nijssen, 1991. Modellen rundveehouderij: over-zicht en samenhang modellen voor simulatie van melkveebedrijven. Lelystad, Proefstation voor de Rundveehouderij, Schapenhouderij en Paardenhouderij, publicatie nr. 72.

Nichols, P. G. H. and Norton, M. R. (2016) 'Improvement of pasture and forage legumes and grasses for Mediterranean climate zones', Options Méditerranéennes. Série A, Séminaires Méditerranéens, (114), pp. 157-167. Available at:

http://search.ebscohost.com.ezproxy.library.wur.nl/login. aspx?direct=true\&db=lah\&AN=20173015811\&s ite=ehost-live (Accessed: 19 May 2020).

OURRY, A., GONZALEZ, B., BIGOT, J., BOUCAND, J. \& SALETTE, J. (1989). Nitrogen and carbohydrate mobilisations during regrowth of defoliated Lolium perenne L. In Proceedings of the XVI International Grassland Congress, Nice, France 1, 513-514. Nice: Association Française pour la Production Fourrage.

Reed, K. F. M. and Smith, K. F. (2001) 'Adaptation of perennial grasses to a long dry summer'. Edited by P. Monjardino, A. da Câmara, and V. Carnide. Available at:

http://search.ebscohost. com.ezproxy. library. wur.nl/login. aspx?direct=true\&db=lah\&AN=20023028343\&s ite=ehost-live (Accessed: 19 May 2020).

Rogers, M. J., Lawson, A. and Kelly, K. (2017) 'Strategies to enhance perennial ryegrass persistence over summer', 'Doing More with Less', Proceedings of the 18th Australian Agronomy Conference 2017, Ballarat, Victoria, Australia, 24-28 September 2017. Edited by G. J. O'Leary, R. D. Armstrong, and L. Hafner, pp. 1-2. Available at:

http://search.ebscohost.com.ezproxy.library. wur.nl/login. aspx?direct=true\&db=lah\&AN $=20183145611 \& \mathrm{~s}$ ite=ehost-live (Accessed: 19 May 2020).

Schoot J.R. van der en Schilder, H. (2018). Rassenbericht Grasland 2018. Wageningen Livestock Research rapport 1136.

Schils, R.L.M., M.H.A. de Haan, J.G.A. Hemmer, A. van den Pol-van Dasselaar, J.A. de Boer, A.G. Evers, G. Holshof, J.C. van Middelkoop en R.L.G. Zom, 2007. DairyWise, A Whole-Farm Dairy Model. Journal of Dairy Science 90: $5334-5346$.

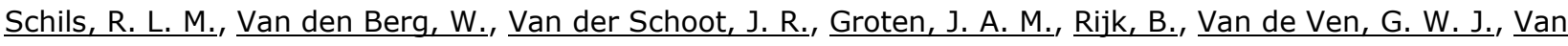
Middelkoop, J. C., Holshof, G. \& van Ittersum, M. K., (2020) Disentangling genetic and non-genetic components of yield trends of Dutch forage crops in the Netherlands. In : Field Crops Research. 249, 107755

Sikkema, 1997. Beoordeling grasland- en slootvegetatie. PV, Lelystad. Handleiding. 
Tabellenboek Veevoeding, 2002. Voedernormen landbouwhuisdieren en voederwaarde veevoeders. Centraal Veevoederbureau, Lelystad.

TALLOWIN, J. R. B., BROOKMAN, S. K. E. \& SANTOS, G. L. (1995). Leaf growth and utilization in four grass species under steady state continuous grazing. Journal of Agricultural Science, Cambridge 124, 403-417.

TAKASAKI, Y., ISODA, A., NOJIMA, H. \& OIZUMI, H. (1989). Behaviours of annual and perennial grass species in the same genus. In Proceedings of the XVI International Grassland Congress, Nice, France. vol. 1, 449-450. Nice: Association Française pour la Production Fourrage.

Tozer, K. N. et al. (2017) 'Growth responses of diploid and tetraploid perennial ryegrass (Lolium perenne) to soil-moisture deficit, defoliation and a root-feeding invertebrate'. \& Pasture Science, 2017, 68, 632-642 https://doi.org/10.1071/CP17154

Vellinga, Th.V., 1998. Verfijning bemestingsadvies 1998. Praktijkonderzoek Veehouderij, Lelystad. Rapport 173

Vliegher, A. de, Grunert, O., Carlier, L., 2002. Weidevernieuwing: invloed van ouderdom van de weide op de productiviteit. In: Brochure Voedergewassen 2002, Oogst 2001, Landbouwcentrum voor Voedergewassen, Geel, Belgie: 69-78

Volaire F, Norton MR, Lelièvre F. (2009) Summer drought survival strategies and sustainability of perennial temperate forage grasses in Mediterranean areas. Crop Science 49, 2386-2392. doi: 10.2135/cropsci2009.06.0317

Vos, J.A. de, P.J.T. van Bakel, I.E. Hoving en J.G. Conijn, 2006. Waterpas-model: a predictive tool for water management, agriculture, and environment. Agric. Wat. Man. 86(1-2): 187-195.

Wilkins, P.W and M.O Humphreys, 2003. Progress in breeding perennial forage grasses for temperate agriculture J. Agric. Sci. Camb., 140 (2003), pp. 129-150.

Woldring, J.J., 1975. Invloed van herinzaai en stikstof op de opbrengst en de botanische samenstelling van grasland. Tweede verslag van een proef te Gilze van 1971 t/m 1974. Rapport 35, Proefstation voor de Rundveehouderij, Lelystad: $21 \mathrm{pp}$.

Woodward, S. J. R. et al. (2020) 'Identifying causes of low persistence of perennial ryegrass (Lolium perenne) dairy pasture using the Basic Frassland model (BASGRA)', Grass and Forage Science, 75(1), pp. 45-63. Available at:

http://search.ebscohost.com.ezproxy.library. wur.nl/login. aspx?direct=true\&db=lah\&AN=20203138474\&s ite=ehost-live (Accessed: 19 May 2020).

Werkgroep Normen Voor de Voedervoorziening, 1991. Normen Voor de Voedervoorziening. Lelystad, PR, publicatie 70.

Westermeier, P. et al. (2015) 'Genetic variation of drought tolerance in perennial ryegrass (Lolium perenne L.) - evaluation of phenotypic selection traits. / Genetische Variation des Merkmals Trockentoleranz in Deutschem Weidelgras (Lolium perenne L.) - Evaluierung phänotypischer Selektionsmerkmale', 65. Tagung Zukünftiges Saatgut - Produktion, Vermarktung, Nutzung und Konzervierung. Future Seed Production, Marketing, Use and Conservation. 24-26 November, 2014 Raumberg-Gumpenstein, Austria, pp. 51-55. Available at:

http://search.ebscohost. com.ezproxy.library. wur.nl/login. aspx?direct=true\&db=lah\&AN=20163005818\&s ite=ehost-live (Accessed: 19 May 2020).

Westermeier, P. et al. (2016) 'Variation in drought tolerance of perennial ryegrass (Lolium perenne L.)', Breeding in a world of scarcity. 31st Eucarpia Fodder Crops and Amenity Grasses Congress, Ghent, Belgium, 13-17 September 2015. Edited by I. Roldán-Ruiz, J. Baert, and D. Reheul, pp. 63-68. Available at:

http://search.ebscohost.com.ezproxy.library. wur.nl/login. aspx?direct=true\&db=lah\&AN=20183191202\&s ite=ehost-live (Accessed: 19 May 2020).

Woodman, R. F., Keoghan, J. M. and Allan, B. E. (1992) 'Pasture species for drought-prone lower slopes in the South Island high country', Proceedings of the New Zealand Grassland Association, 54, pp. 115-120.

Available at:

http://search.ebscohost.com.ezproxy.library.wur.nl/login.aspx?direct=true\&db=lah\&AN=19940703961\&s ite=ehost-live (Accessed: 19 May 2020).

Wösten, J.H.M., J.H. Bannink en J. Beuving (1987). Waterretentie- en doorlatendheidskarakteristieken van boven- en ondergronden in Nederland: de Staringreeks. Wageningen. Stiboka-rapport 1932, ICWrapport 18. Stiboka/ ICW, Wageningen.

Zom, R.L.G, J.W. van Riel, G. André en G. van Duinkerken, 2002. Voorspelling voeropname met Koemodel 2002. Lelystad, Praktijkonderzoek Veehouderij, Praktijkrapport Rundvee 11. 


\section{Bijlage 1 Grondwaterstanden}

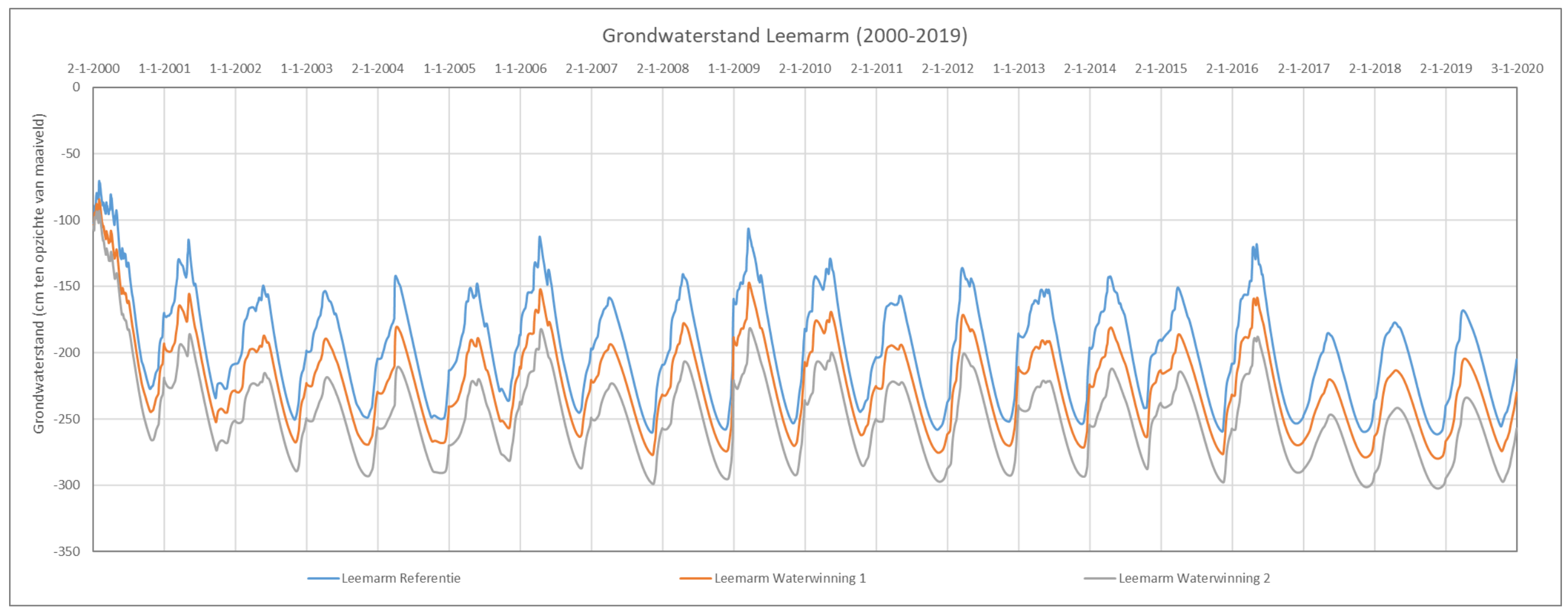

Figuur B1.1 Grondwaterstanden voor het bodemtype Leemarm en de varianten Referentie, Waterwinning 1 en Waterwinning 2 voor de weerjaren $2000-2019$ 


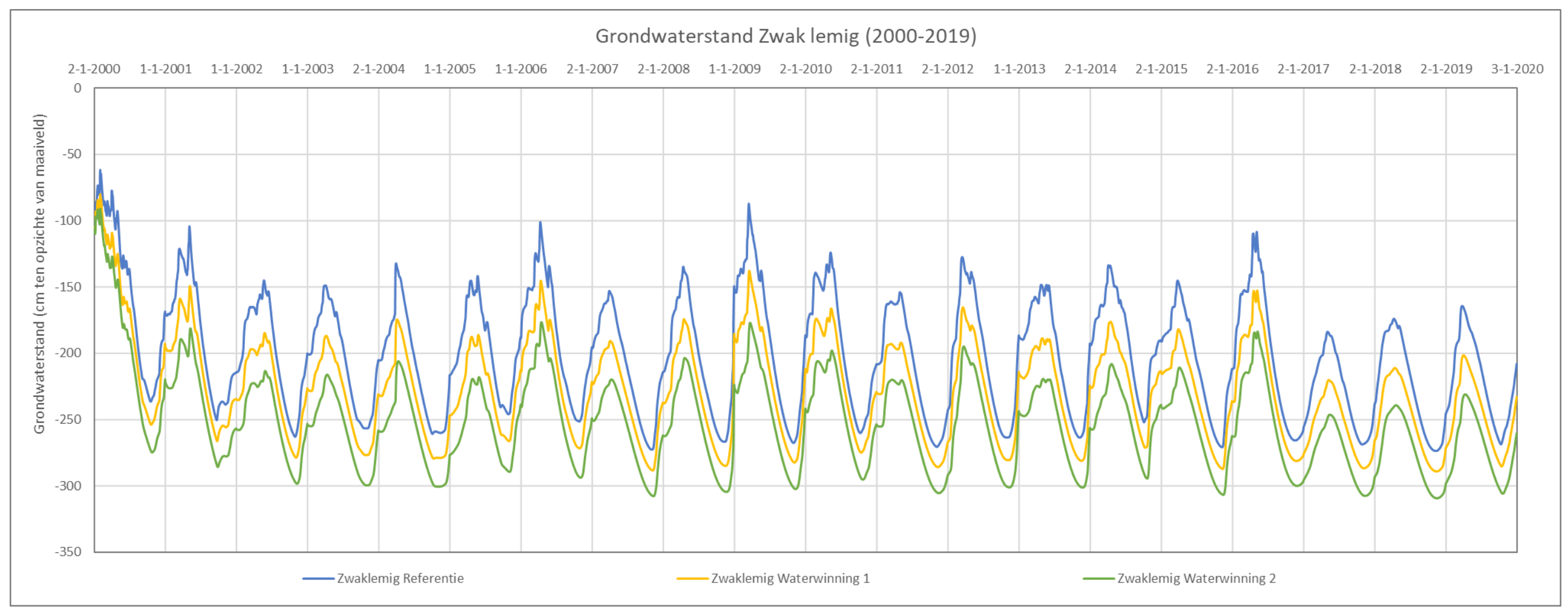

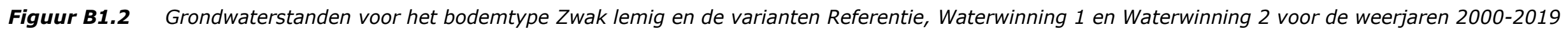

Openbaar Wageningen Livestock Research Rapport 1296

58 


\section{Bijlage 2 Drukhoogte wortelzone}

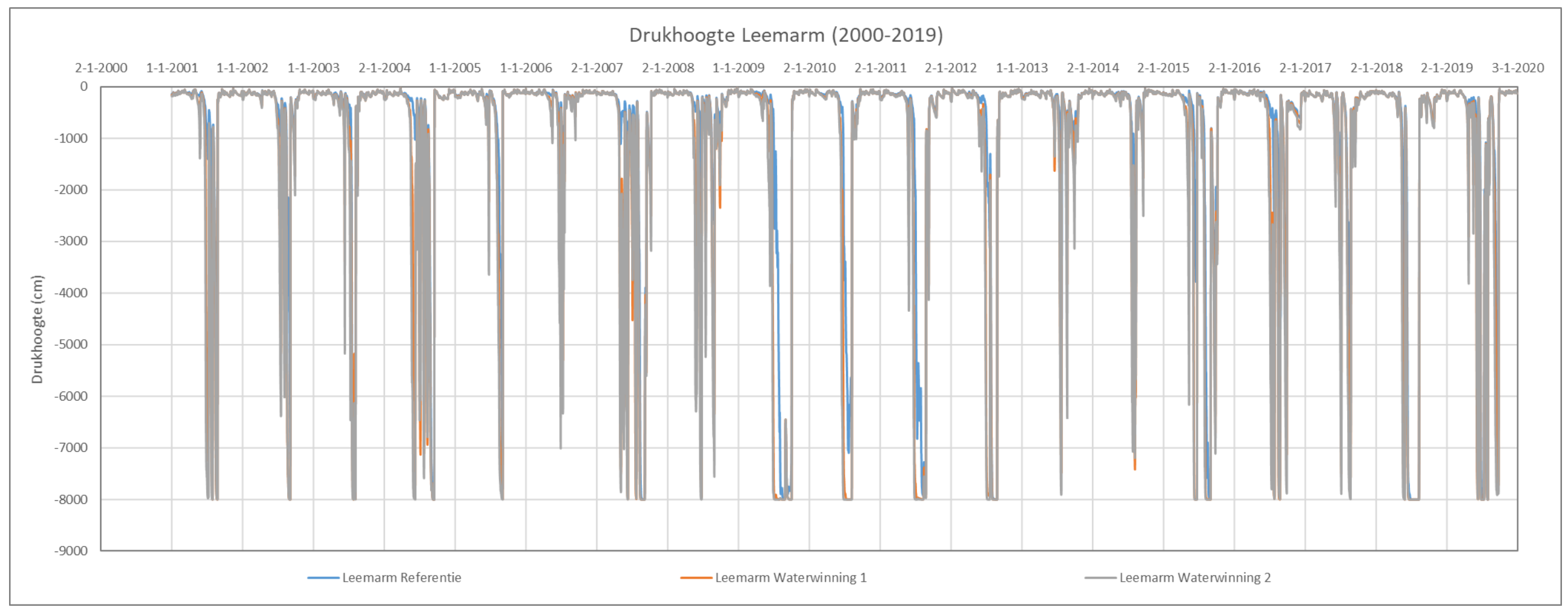

Figuur B2.1 Drukhoogte $(\mathrm{cm})$ in de wortelzone voor het bodemtype Leemarm en de varianten Referentie, Waterwinning 1 en Waterwinning 2 voor de weerjaren 2000-2019 


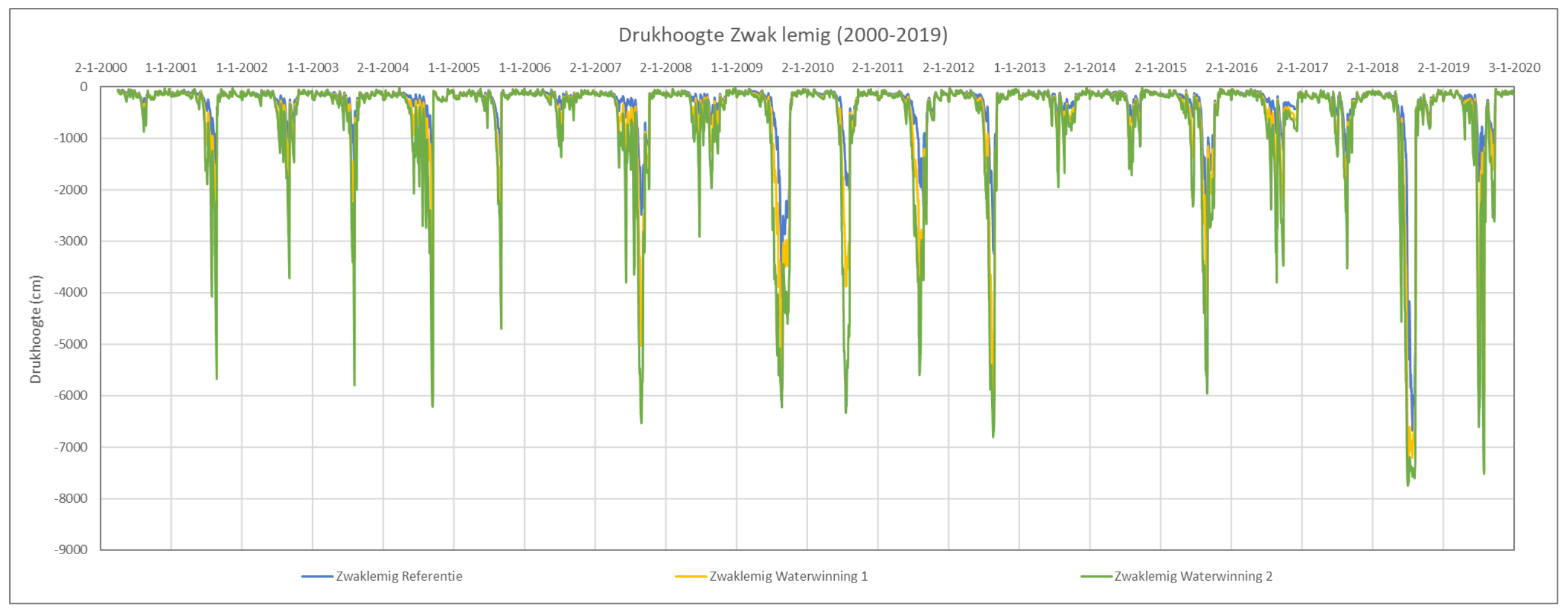

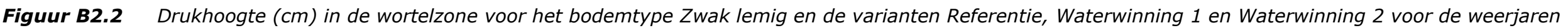
2000-2019 


\section{Bijlage 3 Melk- en voerproductie}

Tabel B3.1 Gemiddelde waarden voor melk-en voerproductie voor de potentiele productie en de bodemtypen Zwak lemig en Leemarm met de droogtevarianten Referentie, Waterwinning 1 en Waterwinning 2.

\begin{tabular}{|c|c|c|c|c|c|c|c|c|}
\hline 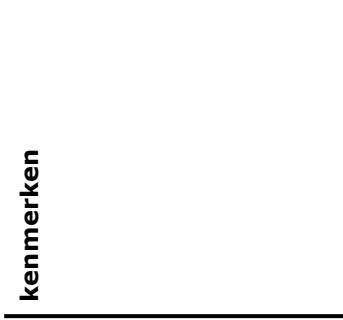 & 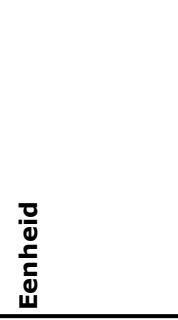 & 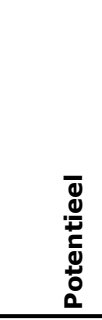 & 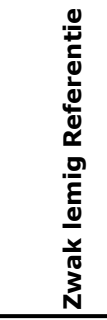 & 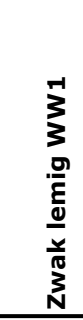 & 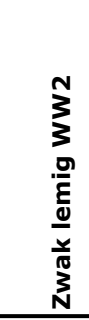 & 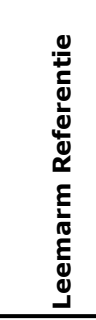 & 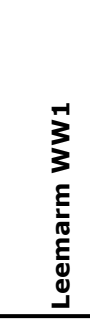 & 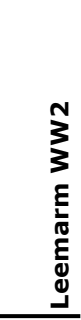 \\
\hline Melkproductie per koe & (kg/koe) & 8712 & 8795 & 8868 & 8901 & 8866 & 8914 & 8922 \\
\hline $\mathrm{N}$-jaargift grasland & (kg/ha) & 232 & 237 & 240 & 246 & 240 & 242 & 244 \\
\hline Bruto grasopbrengst & (kg ds/ha) & 11342 & 10065 & 8871 & 8154 & 9016 & 7983 & 7701 \\
\hline Netto grasopbrengst & (kVEM/ha) & 8480 & 7466 & 6550 & 5979 & 6674 & 5855 & 5632 \\
\hline Maaipercentage $1^{\mathrm{e}}$ snede & $(\%)$ & 57 & 56 & 55 & 55 & 56 & 56 & 56 \\
\hline Maaipercentage overige & $(\%)$ & 179 & 187 & 197 & 203 & 208 & 210 & 217 \\
\hline Maaipercentage beheer & $(\%)$ & 0 & 0 & 0 & 0 & 0 & 0 & 0 \\
\hline Maaipercentage totaal & (\%) & 235 & 243 & 252 & 258 & 264 & 266 & 273 \\
\hline Voeropbrengst & (ton ds) & 322 & 286 & 246 & 225 & 256 & 222 & 214 \\
\hline Energie voer totaal & (VEM/kg ds) & 885 & 882 & 880 & 878 & 881 & 881 & 880 \\
\hline Zelfvoorzieningsgraad & $(\%)$ & 73 & 65 & 58 & 54 & 59 & 53 & 52 \\
\hline
\end{tabular}

Tabel B3.2

Standaard afwijking voor melk- en voerproductie voor de potentiele productie en de bodemtypen Zwak lemig en Leemarm met de droogtevarianten Referentie, Waterwinning 1 en Waterwinning 2.

\begin{tabular}{|c|c|c|c|c|c|c|c|c|}
\hline 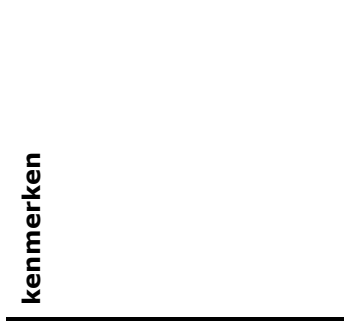 & 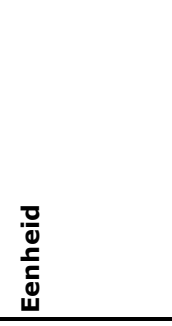 & 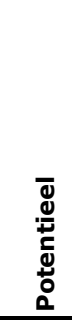 & 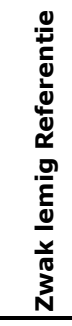 & 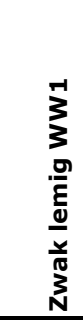 & 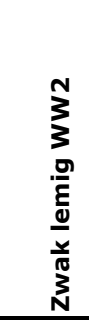 & 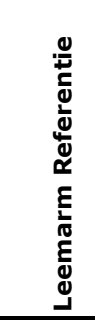 & 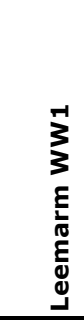 & 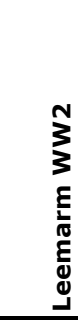 \\
\hline Melkproductie per koe & (kg/koe) & 33 & 60 & 79 & 80 & 80 & 83 & 85 \\
\hline $\mathrm{N}$-jaargift grasland & (kg/ha) & 4 & 6 & 7 & 17 & 5 & 6 & 5 \\
\hline Bruto grasopbrengst & (kg ds/ha) & 312 & 943 & 1305 & 1516 & 1257 & 1591 & 1703 \\
\hline Netto grasopbrengst & (kVEM/ha) & 237 & 745 & 1020 & 1161 & 960 & 1211 & 1304 \\
\hline Maaipercentage $1^{\mathrm{e}}$ snede & $(\%)$ & 3 & 3 & 4 & 4 & 4 & 5 & 7 \\
\hline Maaipercentage overige & $(\%)$ & 11 & 38 & 54 & 58 & 51 & 45 & 38 \\
\hline Maaipercentage beheer & $(\%)$ & 0 & 0 & 0 & 0 & 0 & 0 & 0 \\
\hline Maaipercentage totaal & $(\%)$ & 11 & 37 & 52 & 57 & 49 & 45 & 36 \\
\hline Voeropbrengst & (ton ds) & 11 & 35 & 45 & 53 & 45 & 53 & 54 \\
\hline Energie voer totaal & (VEM/kg ds) & 3 & 6 & 10 & 7 & 10 & 8 & 9 \\
\hline Zelfvoorzieningsgraad & $(\%)$ & 2 & 6 & 8 & 8 & 7 & 9 & 9 \\
\hline
\end{tabular}


Tabel B3.3 Minimale waarden voor melk- en voerproductie voor de potentiele productie en de bodemtypen Zwak lemig en Leemarm met de droogtevarianten Referentie, Waterwinning 1 en Waterwinning 2.

\begin{tabular}{|c|c|c|c|c|c|c|c|c|}
\hline 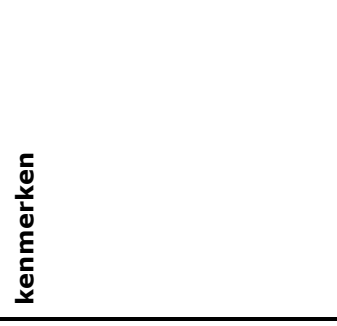 & 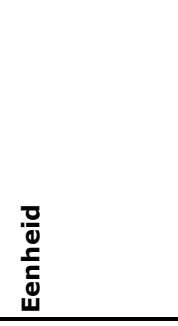 & 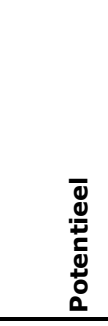 & 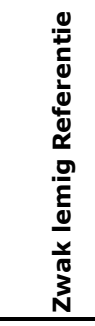 & 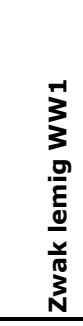 & $\begin{array}{l}\mathbf{N} \\
\mathbf{3} \\
\mathbf{3} \\
\mathbf{0} \\
\mathbf{E} \\
\frac{0}{0} \\
\frac{\mathbf{0}}{0} \\
\mathbf{3} \\
\mathbf{N}\end{array}$ & 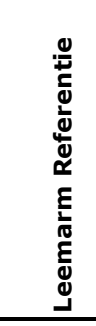 & 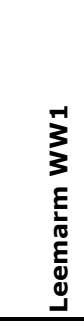 & $\begin{array}{l}\mathbf{N} \\
3 \\
\mathbf{3} \\
\mathbf{E} \\
\frac{5}{0} \\
\mathbf{E} \\
\mathbb{d} \\
\end{array}$ \\
\hline Melkproductie per koe & (kg/koe) & 8656 & 8715 & 8715 & 8733 & 8707 & 8734 & 8738 \\
\hline $\mathrm{N}$-jaargift grasland & (kg/ha) & 226 & 227 & 227 & 229 & 229 & 229 & 236 \\
\hline Bruto grasopbrengst & (kg ds/ha) & 10645 & 7224 & 5933 & 5595 & 6317 & 5581 & 5343 \\
\hline Netto grasopbrengst & (kVEM/ha) & 7954 & 5189 & 4139 & 3992 & 4597 & 3923 & 3817 \\
\hline Maaipercentage $1^{\mathrm{e}}$ snede & $(\%)$ & 47 & 47 & 47 & 47 & 47 & 47 & 47 \\
\hline Maaipercentage overige & $(\%)$ & 152 & 135 & 105 & 124 & 122 & 122 & 146 \\
\hline Maaipercentage beheer & $(\%)$ & 0 & 0 & 0 & 0 & 0 & 0 & 0 \\
\hline Maaipercentage totaal & $(\%)$ & 205 & 194 & 164 & 182 & 181 & 181 & 205 \\
\hline Voeropbrengst & (ton ds) & 294 & 167 & 133 & 133 & 141 & 135 & 131 \\
\hline Energie voer totaal & (VEM/kg ds) & 879 & 865 & 854 & 866 & 854 & 869 & 863 \\
\hline Zelfvoorzieningsgraad & $(\%)$ & 67 & 46 & 40 & 40 & 42 & 39 & 40 \\
\hline
\end{tabular}

Tabel B3.4 Maximale waarden voor melk- en voerproductie voor de potentiele productie en de bodemtypen Zwak lemig en Leemarm met de droogtevarianten Referentie, Waterwinning 1 en Waterwinning 2.

\begin{tabular}{|c|c|c|c|c|c|c|c|c|}
\hline 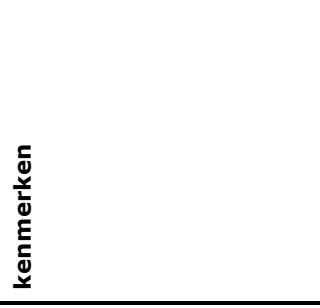 & 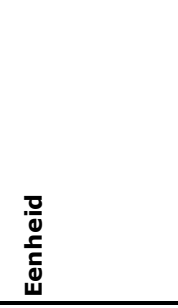 & 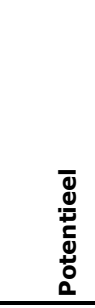 & 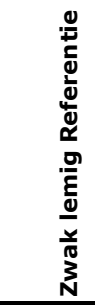 & $\begin{array}{l}-1 \\
3 \\
3 \\
.0 \\
\frac{\sigma}{\sigma} \\
\frac{0}{5} \\
\frac{\pi}{\pi} \\
\frac{3}{N}\end{array}$ & 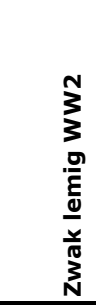 & 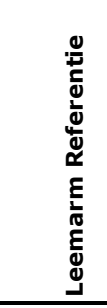 & 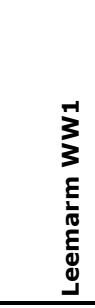 & 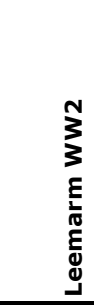 \\
\hline Melkproductie per koe & (kg/koe) & 8788 & 8921 & 8968 & 9001 & 8957 & 9030 & 9021 \\
\hline $\mathrm{N}$-jaargift grasland & (kg/ha) & 238 & 251 & 260 & 312 & 249 & 257 & 256 \\
\hline Bruto grasopbrengst & (kg ds/ha) & 11871 & 11340 & 11155 & 10874 & 11335 & 10759 & 10951 \\
\hline Netto grasopbrengst & (kVEM/ha) & 8867 & 8467 & 8331 & 7973 & 8452 & 7910 & 8107 \\
\hline Maaipercentage $1^{\mathrm{e}}$ snede & $(\%)$ & 59 & 59 & 59 & 59 & 59 & 65 & 70 \\
\hline Maaipercentage overige & $(\%)$ & 199 & 250 & 327 & 327 & 310 & 278 & 296 \\
\hline Maaipercentage beheer & $(\%)$ & 0 & 0 & 0 & 0 & 0 & 0 & 0 \\
\hline Maaipercentage totaal & $(\%)$ & 258 & 309 & 374 & 383 & 357 & 337 & 349 \\
\hline Voeropbrengst & (ton ds) & 343 & 315 & 316 & 316 & 329 & 329 & 319 \\
\hline Energie voer totaal & (VEM/kg ds) & 890 & 891 & 896 & 890 & 895 & 898 & 898 \\
\hline Zelfvoorzieningsgraad & $(\%)$ & 77 & 72 & 72 & 69 & 73 & 70 & 69 \\
\hline
\end{tabular}


Tabel B3.5 Verschil melk- en voerproductie ten opzichte van de potentiele productie voor de bodemtypen Zwak lemig en Leemarm met de droogtevarianten Referentie, Waterwinning 1 en Waterwinning 2.

\begin{tabular}{|c|c|c|c|c|c|c|c|c|}
\hline 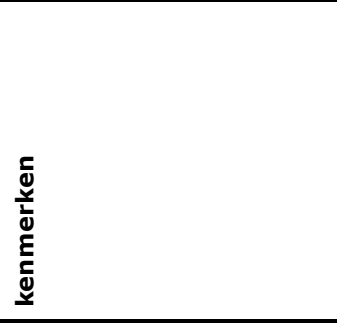 & 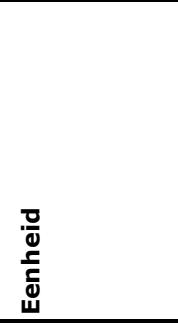 & 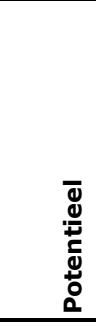 & 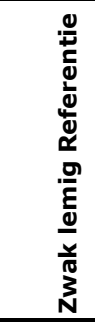 & 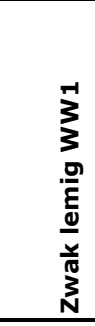 & 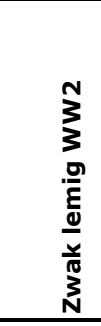 & 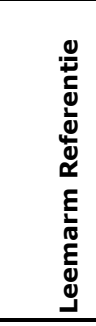 & 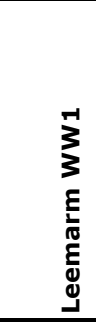 & 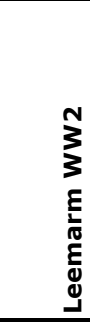 \\
\hline Melkproductie per koe & (kg/koe) & 8712 & 83 & 156 & 189 & 154 & 202 & 210 \\
\hline $\mathrm{N}$-jaargift grasland & (kg/ha) & 232 & 5 & 8 & 14 & 8 & 10 & 12 \\
\hline Bruto grasopbrengst & (kg ds/ha) & 11342 & -1277 & -2470 & -3188 & -2326 & -3359 & -3640 \\
\hline Netto grasopbrengst & (kVEM/ha) & 8480 & -1014 & -1930 & -2501 & -1806 & -2625 & -2848 \\
\hline Maaipercentage $1^{\mathrm{e}}$ snede & $(\%)$ & 57 & -1 & -2 & -2 & -1 & -1 & -1 \\
\hline Maaipercentage overige & $(\%)$ & 179 & 8 & 18 & 24 & 29 & 31 & 38 \\
\hline Maaipercentage beheer & $(\%)$ & 0 & 0 & 0 & 0 & 0 & 0 & 0 \\
\hline Maaipercentage totaal & $(\%)$ & 235 & 8 & 17 & 23 & 29 & 31 & 38 \\
\hline Voeropbrengst & (ton ds) & 322 & -36 & -76 & -97 & -67 & -100 & -108 \\
\hline Energie voer totaal & (VEM/kg ds) & 885 & -3 & -5 & -7 & -4 & -4 & -5 \\
\hline Zelfvoorzieningsgraad & $(\%)$ & 73 & -8 & -15 & -19 & -14 & -20 & -21 \\
\hline
\end{tabular}




\section{Bijlage 4 Grasopname}

Tabel B4.1 Gemiddelde waarden voor grasopname voor de potentiële productie en de bodemtypen Zwak lemig en Leemarm met de droogtevarianten Referentie, Waterwinning 1 en Waterwinning 2.

\begin{tabular}{|c|c|c|c|c|c|c|c|c|}
\hline 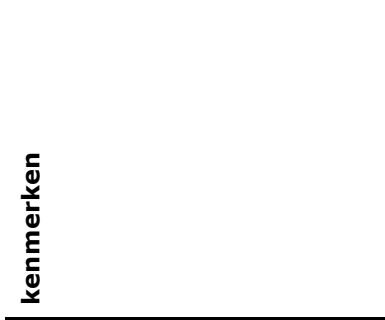 & 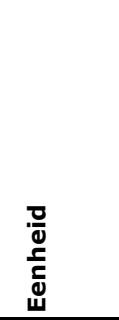 & 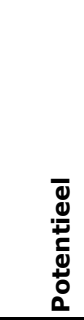 & 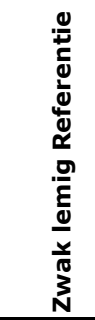 & 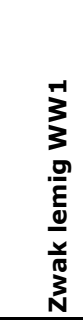 & 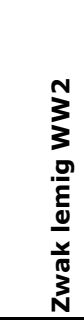 & 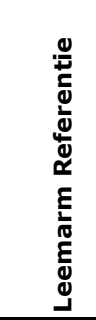 & 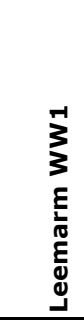 & 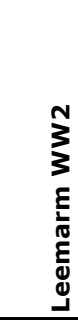 \\
\hline Opname gras per koe & (kg ds) & 1457 & 1270 & 1145 & 1039 & 1129 & 1003 & 964 \\
\hline Opname ruwvoer per koe & $(\mathrm{kg} \mathrm{ds})$ & 3551 & 3796 & 3981 & 4109 & 3990 & 4151 & 4195 \\
\hline Opname bijproducten per koe & (kg ds) & 0 & 0 & 0 & 0 & 0 & 0 & 0 \\
\hline Opname krachtvoer per koe & $(\mathrm{kg})$ & 2565 & 2583 & 2596 & 2608 & 2598 & 2613 & 2619 \\
\hline
\end{tabular}

Tabel B4.2 Standaard afwijking voor grasopname voor de potentiële productie en de bodemtypen Zwak 1 emig en Leemarm met de droogtevarianten Referentie, Waterwinning 1 en Waterwinning 2.

\begin{tabular}{|c|c|c|c|c|c|c|c|c|}
\hline 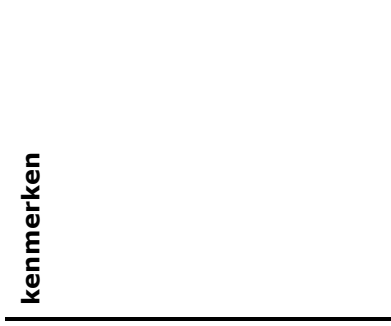 & 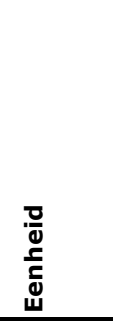 & 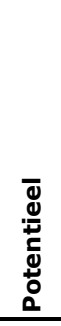 & 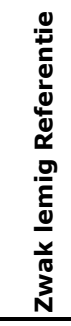 & $\begin{array}{l}-1 \\
3 \\
3 \\
0 \\
\frac{0}{2} \\
\frac{\pi}{5} \\
\frac{5}{\pi} \\
\frac{N}{N}\end{array}$ & 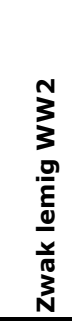 & 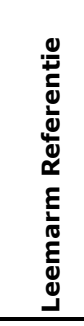 & 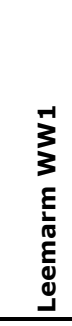 & 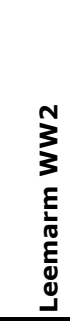 \\
\hline Opname gras per koe & $(\mathrm{kg} \mathrm{ds})$ & 40 & 150 & 180 & 206 & 173 & 201 & 229 \\
\hline Opname ruwvoer per koe & $(\mathrm{kg} \mathrm{ds})$ & 63 & 178 & 230 & 253 & 221 & 251 & 276 \\
\hline Opname bijproducten per koe & (kg ds) & 0 & 0 & 0 & 0 & 0 & 0 & 0 \\
\hline Opname krachtvoer per koe & $(\mathrm{kg})$ & 8 & 16 & 20 & 23 & 18 & 22 & 26 \\
\hline
\end{tabular}

Tabel B4.3 Minimale waarden voor grasopname voor de potentiële productie en de bodemtypen Zwak lemig en Leemarm met de droogtevarianten Referentie, Waterwinning 1 en Waterwinning 2.

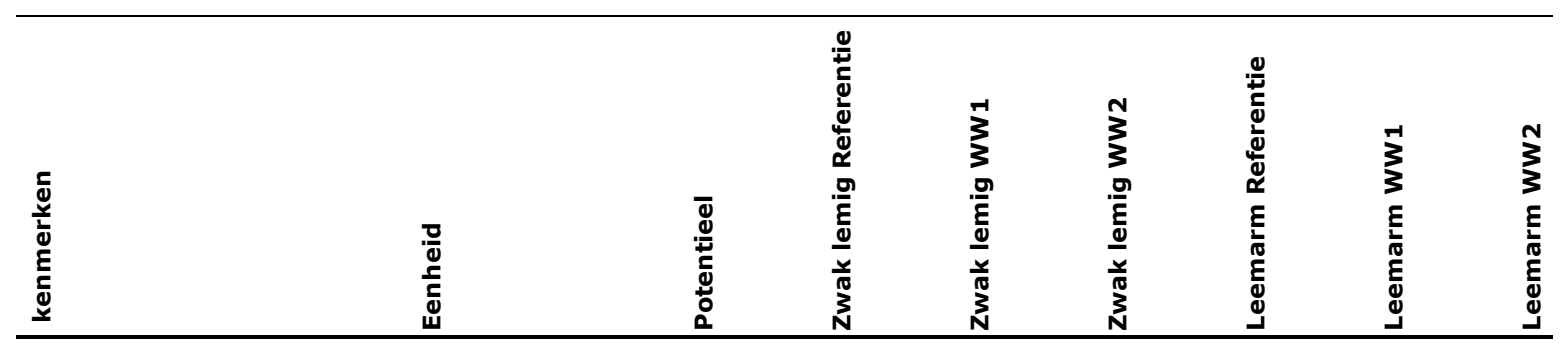

\begin{tabular}{|c|c|c|c|c|c|c|c|c|}
\hline Opname gras per koe & (kg ds) & 1367 & 965 & 827 & 729 & 814 & 700 & 603 \\
\hline Opname ruwvoer per koe & (kg ds) & 3448 & 3541 & 3592 & 3618 & 3609 & 3699 & 3596 \\
\hline Opname bijproducten per koe & $(\mathrm{kg} \mathrm{ds})$ & 0 & 0 & 0 & 0 & 0 & 0 & 0 \\
\hline Opname krachtvoer per koe & $(\mathrm{kg})$ & 2553 & 2559 & 2566 & 2566 & 2570 & 2574 & 2566 \\
\hline
\end{tabular}


Tabel B4.4 Maximale waarden voor grasopname voor de potentiële productie en de bodemtypen Zwak lemig en Leemarm met de droogtevarianten Referentie, Waterwinning 1 en Waterwinning 2.

\begin{tabular}{llrrrrrrr}
\hline & & & & & & & & \\
& & & & & & & & \\
\hline
\end{tabular}

Tabel B4.5 Verschil grasopname ten opzichte van de potentiële productie voor de bodemtypen Zwak lemig en Leemarm met de droogtevarianten Referentie, Waterwinning 1 en Waterwinning 2.

\begin{tabular}{|c|c|c|c|c|c|c|c|c|}
\hline 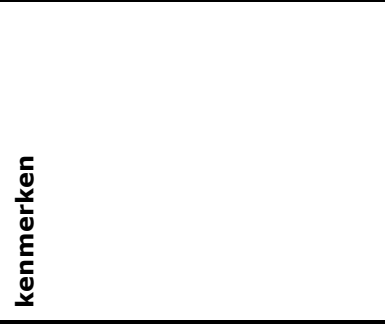 & 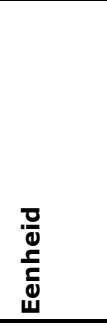 & 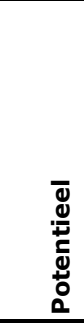 & 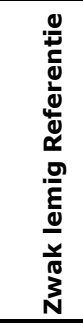 & 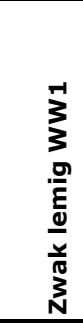 & 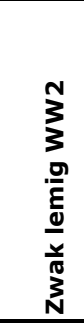 & 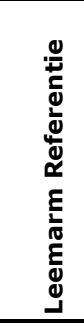 & 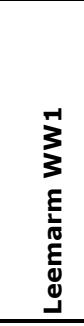 & 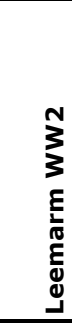 \\
\hline Opname gras per koe & (kg ds) & 1457 & -187 & -312 & -418 & -328 & -454 & -493 \\
\hline Opname ruwvoer per koe & (kg ds) & 3551 & 245 & 430 & 558 & 439 & 600 & 644 \\
\hline Opname bijproducten per koe & (kg ds) & 0 & 0 & 0 & 0 & 0 & 0 & 0 \\
\hline Opname krachtvoer per koe & $(\mathrm{kg})$ & 2565 & 18 & 31 & 43 & 33 & 48 & 54 \\
\hline
\end{tabular}




\section{Bijlage 5 Invoer HerinzaaiWijzer bij herinzaai eens in de 14 jaar}

Tabel B5.1 Invoer HerinzaaiWijzer berekening gemiddelde verandering in drogestofopbrengst van gras na herinzaai per droogtevariant per ha per jaar voor het bodemtype zwak lemig fijn zand.

\begin{tabular}{|c|c|c|c|}
\hline Uitgangspunten HerinzaaiWijzer & Referentie & Waterwinning 1 & Waterwinning 2 \\
\hline \multicolumn{4}{|l|}{ Algemeen } \\
\hline Herinzaai (\#/jaar) & 14 & 14 & 14 \\
\hline Fractie maaien $(\%)$ & 55 & 56 & 56 \\
\hline Moment herinzaai in het jaar & najaar & najaar & najaar \\
\hline \multicolumn{4}{|l|}{ Voederwaarde } \\
\hline Voederwaarde (VEM en DVE) potentieel (\%) & 100 & 100 & 100 \\
\hline Voederwaarde lange termijn (\%) & 90 & 90 & 90 \\
\hline \multicolumn{4}{|l|}{$\mathrm{N}$-uitspoeling } \\
\hline $\mathrm{N}$-verlies (kg N/ha) & 180 & 180 & 180 \\
\hline Marginaal stikstofeffect $(\mathrm{kg} / \mathrm{kg} \mathrm{N})$ & 11 & 11 & 11 \\
\hline \multicolumn{4}{|l|}{ Rendement weiden } \\
\hline Potentieel rendement (\%) & 83 & 83 & 83 \\
\hline Rendement lange termijn (\%) & 75 & 75 & 75 \\
\hline \multicolumn{4}{|l|}{ Rendement maaien } \\
\hline Potentieel rendement $(\%)$ & 85 & 85 & 85 \\
\hline Rendement lange termijn (\%) & 80 & 80 & 80 \\
\hline \multicolumn{4}{|l|}{ Productie } \\
\hline Berekende productie Waterpas & 10065 & 8871 & 8154 \\
\hline Productie lange termijn (\%) & 70 & 70 & 70 \\
\hline Extra productie jaar $1(\%)$ & 10 & 10 & 10 \\
\hline Verloop jaar 1-5 (\%/jaar) & 40 & 40 & 40 \\
\hline Verloop jaar 5-20 (\%/jaar) & 14,23 & 14,23 & 14,23 \\
\hline Verlies potentiële productie jaar 0 najaar (\%) & 25 & 25 & 25 \\
\hline
\end{tabular}


Tabel B5.2 Invoer HerinzaaiWijzer berekening gemiddelde verandering in drogestofopbrengst van gras na herinzaai per droogtevariant per ha per jaar voor het bodemtype leemarm fijn zand.

\begin{tabular}{|c|c|c|c|}
\hline Uitgangspunten HerinzaaiWijzer & Referentie & Waterwinning 1 & Waterwinning 2 \\
\hline \multicolumn{4}{|l|}{ Algemeen } \\
\hline Herinzaai (\#/jaar) & 14 & 14 & 14 \\
\hline Fractie maaien (\%) & 57 & 57 & 57 \\
\hline Moment herinzaai in het jaar & najaar & najaar & najaar \\
\hline \multicolumn{4}{|l|}{ Voederwaarde } \\
\hline Voederwaarde (VEM en DVE) potentieel (\%) & 100 & 100 & 100 \\
\hline Voederwaarde lange termijn (\%) & 90 & 90 & 90 \\
\hline \multicolumn{4}{|l|}{ N-uitspoeling } \\
\hline N-verlies (kg N/ha) & 180 & 180 & 180 \\
\hline Marginaal stikstofeffect $(\mathrm{kg} / \mathrm{kg} \mathrm{N})$ & 11 & 11 & 11 \\
\hline \multicolumn{4}{|l|}{ Rendement weiden } \\
\hline Potentieel rendement (\%) & 83 & 83 & 83 \\
\hline Rendement lange termijn (\%) & 75 & 75 & 75 \\
\hline \multicolumn{4}{|l|}{ Rendement maaien } \\
\hline Potentieel rendement (\%) & 85 & 85 & 85 \\
\hline Rendement lange termijn (\%) & 80 & 80 & 80 \\
\hline \multicolumn{4}{|l|}{ Productie } \\
\hline Berekende productie Waterpas & 9016 & 7983 & 7701 \\
\hline Productie lange termijn (\%) & 70 & 70 & 70 \\
\hline Extra productie jaar $1(\%)$ & 10 & 10 & 10 \\
\hline Verloop jaar 1-5 (\%/jaar) & 40 & 40 & 40 \\
\hline Verloop jaar 5-20 (\%/jaar) & 14,23 & 14,23 & 14,23 \\
\hline Verlies potentiële productie jaar 0 najaar (\%) & 25 & 25 & 25 \\
\hline
\end{tabular}




\section{Bijlage 6 Grasopbrengstverloop bij herinzaai eens in de 14 jaar}

Tabel B6.1 Bruto grasopbrengst, opbrengstvermindering door stikstofverlies, verloop voederwaarde en rendement weiden en maaien, aandeel maaien, netto voederwaardeopbrengst en de waarde van de netto grasopbrengst voor het bodemtype Zwak lemig en droogtevariant Referentie gesimuleerd voor melkveeproefbedrijf De Marke bij herinzaai eens in de 14 jaar.

\begin{tabular}{|c|c|c|c|c|c|c|c|c|c|c|c|c|c|}
\hline \multirow{3}{*}{$\begin{array}{l}\text { Variant } \\
\text { Zwak lemig } \\
\text { Droog } \\
\end{array}$} & \multicolumn{2}{|c|}{ Bruto grasproductie (kg ds/ha) } & \multicolumn{4}{|l|}{ Degeneratie } & \multicolumn{2}{|c|}{ Netto voederwaarde } & \multicolumn{2}{|c|}{ Netto voederwaardeopbrengst } & \multicolumn{3}{|c|}{ Waarde netto grasopbrengst (euro) } \\
\hline & \multirow[t]{2}{*}{ Productie } & \multirow{2}{*}{$\begin{array}{l}\text { Verlaging door } \\
\mathrm{N} \text {-verlies }\end{array}$} & \multirow{2}{*}{$\begin{array}{l}\text { Voederwaarde } \\
(\%) \\
\end{array}$} & \multicolumn{2}{|c|}{ Rendement (\%) } & \multirow{2}{*}{$\begin{array}{l}\text { Aandeel } \\
\text { maaien }(\%)\end{array}$} & \multirow[t]{2}{*}{ VEM } & \multirow[t]{2}{*}{ DVE } & \multirow[t]{2}{*}{ KVEM } & \multirow[t]{2}{*}{ KDVE } & \multirow[t]{2}{*}{ KVEM } & \multirow[t]{2}{*}{ KDVE } & \multirow[t]{2}{*}{ Totaa } \\
\hline & & & & weiden & maaien & & & & & & & & \\
\hline \multicolumn{14}{|c|}{55} \\
\hline 1 & 9389 & & 100.0 & 83.0 & 85.0 & 84.1 & 987 & 101 & 7794 & 794 & 1325 & 770 & 2095 \\
\hline 2 & 11751 & 152 & 99.7 & 82.7 & 84.8 & 83.9 & 984 & 100 & 9571 & 975 & 1627 & 945 & 2572 \\
\hline 3 & 11220 & 152 & 99.3 & 82.5 & 84.7 & 83.7 & 980 & 100 & 9080 & 925 & 1544 & 897 & 2440 \\
\hline 4 & 10833 & 152 & 99.0 & 82.2 & 84.5 & 83.5 & 977 & 99 & 8711 & 887 & 1481 & 860 & 2341 \\
\hline 5 & 10537 & 152 & 98.7 & 81.9 & 84.3 & 83.3 & 974 & 99 & 8419 & 857 & 1431 & 832 & 2263 \\
\hline 6 & 10299 & 152 & 98.3 & 81.7 & 84.2 & 83.0 & 971 & 99 & 8178 & 833 & 1390 & 808 & 2198 \\
\hline 7 & 10100 & 152 & 98.0 & 81.4 & 84.0 & 82.8 & 967 & 98 & 7970 & 812 & 1355 & 787 & 2142 \\
\hline 8 & 9928 & 152 & 97.7 & 81.1 & 83.8 & 82.6 & 964 & 98 & 7786 & 793 & 1324 & 769 & 2093 \\
\hline 9 & 9777 & 152 & 97.3 & 80.9 & 83.7 & 82.4 & 961 & 98 & 7619 & 776 & 1295 & 753 & 2048 \\
\hline 10 & 9641 & 152 & 97.0 & 80.6 & 83.5 & 82.2 & 957 & 97 & 7467 & 760 & 1269 & 737 & 2007 \\
\hline 11 & 9518 & 152 & 96.7 & 80.3 & 83.3 & 82.0 & 954 & 97 & 7326 & 746 & 1245 & 724 & 1969 \\
\hline 12 & 9405 & 152 & 96.3 & 80.1 & 83.2 & 81.8 & 951 & 97 & 7194 & 733 & 1223 & 711 & 1934 \\
\hline 13 & 9302 & 152 & 96.0 & 79.8 & 83.0 & 81.6 & 948 & 96 & 7071 & 720 & 1202 & 698 & 1900 \\
\hline 14 & 9207 & 152 & 95.7 & 79.5 & 82.8 & 81.3 & 944 & 96 & 6955 & 708 & 1182 & 687 & 1869 \\
\hline 30 & 8381 & & 90.0 & 75.0 & 80.0 & 77.8 & 888 & 90 & 5788 & 589 & 984 & 572 & 1556 \\
\hline Gem & 10065 & 152 & 97.8 & 81.3 & 83.9 & 82.7 & 966 & 98 & 7939 & 808 & 1350 & 784 & 2134 \\
\hline
\end{tabular}


Tabel B6.2 Bruto grasopbrengst, opbrengstvermindering door stikstofverlies, verloop voederwaarde en rendement weiden en maaien, aandeel maaien, netto voederwaardeopbrengst en de waarde van de netto grasopbrengst voor het bodemtype Zwak lemig en droogtevariant Waterwinning 1 gesimuleerd voor melkveeproefbedrijf De Marke bij herinzaai eens in de 14 jaar.

\begin{tabular}{|c|c|c|c|c|c|c|c|c|c|c|c|c|c|}
\hline \multirow{3}{*}{$\begin{array}{l}\text { Variant } \\
\text { Zwak lemig } \\
\text { Waterwinning } 1 \\
\end{array}$} & \multicolumn{2}{|c|}{ Bruto grasproductie (kg ds/ha) } & \multicolumn{4}{|l|}{ Degeneratie } & \multicolumn{2}{|c|}{ Netto voederwaarde } & \multicolumn{2}{|c|}{ Netto voederwaardeopbrengst } & \multicolumn{3}{|c|}{ Waarde netto grasopbrengst (euro) } \\
\hline & \multirow[t]{2}{*}{ Productie } & \multirow{2}{*}{$\begin{array}{l}\text { Verlaging door } \\
\mathrm{N} \text {-verlies }\end{array}$} & \multirow{2}{*}{$\begin{array}{l}\text { Voederwaarde } \\
(\%) \\
\end{array}$} & \multicolumn{2}{|c|}{ Rendement (\%) } & \multirow{2}{*}{$\begin{array}{l}\text { Aandeel } \\
\text { maaien (\%) }\end{array}$} & \multirow[t]{2}{*}{ VEM } & \multirow[t]{2}{*}{ DVE } & \multirow[t]{2}{*}{ KVEM } & \multirow[t]{2}{*}{ KDVE } & \multirow[t]{2}{*}{ KVEM } & \multirow[t]{2}{*}{ KDVE } & \multirow[t]{2}{*}{ Totaa } \\
\hline & & & & weiden & maaien & & & & & & & & \\
\hline \multicolumn{14}{|c|}{56} \\
\hline 1 & 8276 & & 100.0 & 83.0 & 85.0 & 84.1 & 987 & 101 & 6871 & 700 & 1168 & 679 & 1847 \\
\hline 2 & 10357 & 152 & 99.7 & 82.7 & 84.8 & 83.9 & 984 & 100 & 8424 & 858 & 1432 & 832 & 2264 \\
\hline 3 & 9889 & 152 & 99.3 & 82.5 & 84.7 & 83.7 & 980 & 100 & 7990 & 814 & 1358 & 789 & $214 \varepsilon$ \\
\hline 4 & 9549 & 152 & 99.0 & 82.2 & 84.5 & 83.5 & 977 & 99 & 7665 & 781 & 1303 & 757 & 2060 \\
\hline 5 & 9287 & 152 & 98.7 & 81.9 & 84.3 & 83.3 & 974 & 99 & 7408 & 754 & 1259 & 732 & 1991 \\
\hline 6 & 9078 & 152 & 98.3 & 81.7 & 84.2 & 83.1 & 971 & 99 & 7196 & 733 & 1223 & 711 & 1934 \\
\hline 7 & 8902 & 152 & 98.0 & 81.4 & 84.0 & 82.9 & 967 & 98 & 7012 & 714 & 1192 & 693 & 1885 \\
\hline 8 & 8751 & 152 & 97.7 & 81.1 & 83.8 & 82.6 & 964 & 98 & 6850 & 698 & 1165 & 677 & 1841 \\
\hline 9 & 8617 & 152 & 97.3 & 80.9 & 83.7 & 82.4 & 961 & 98 & 6704 & 683 & 1140 & 662 & 1802 \\
\hline 10 & 8497 & 152 & 97.0 & 80.6 & 83.5 & 82.2 & 957 & 97 & 6569 & 669 & 1117 & 649 & 1766 \\
\hline 11 & 8389 & 152 & 96.7 & 80.3 & 83.3 & 82.0 & 954 & 97 & 6445 & 656 & 1096 & 637 & 1732 \\
\hline 12 & 8290 & 152 & 96.3 & 80.1 & 83.2 & 81.8 & 951 & 97 & 6329 & 644 & 1076 & 625 & 1701 \\
\hline 13 & 8199 & 152 & 96.0 & 79.8 & 83.0 & 81.6 & 948 & 96 & 6221 & 633 & 1058 & 614 & 1672 \\
\hline 14 & 8115 & 152 & 95.7 & 79.5 & 82.8 & 81.4 & 944 & 96 & 6119 & 623 & 1040 & 604 & 1645 \\
\hline 30 & 7387 & & 90.0 & 75.0 & 80.0 & 77.8 & 888 & 90 & 5105 & 520 & 868 & 504 & 1372 \\
\hline Gem & 8871 & 152 & 97.8 & 81.3 & 83.9 & 82.8 & 966 & 98 & 6986 & 711 & 1188 & 690 & 1878 \\
\hline
\end{tabular}


Tabel B6.3 Bruto grasopbrengst, opbrengstvermindering door stikstofverlies, verloop voederwaarde en rendement weiden en maaien, aandeel maaien, netto voederwaardeopbrengst en de waarde van de netto grasopbrengst voor het bodemtype Zwak lemig en droogtevariant Waterwinning 2 gesimuleerd voor melkveeproefbedrijf De Marke bij herinzaai eens in de 14 jaar.

\begin{tabular}{|c|c|c|c|c|c|c|c|c|c|c|c|c|c|c|}
\hline \multirow{3}{*}{$\begin{array}{l}\text { Variant } \\
\text { Zwak lemig } \\
\text { Waterwinning } 2 \\
\end{array}$} & \multicolumn{3}{|c|}{ Bruto grasproductie (kg ds/ha) } & \multicolumn{4}{|l|}{ Degeneratie } & \multicolumn{2}{|c|}{ Netto voederwaarde } & \multicolumn{2}{|c|}{ Netto voederwaardeopbrengst } & \multicolumn{3}{|c|}{ Waarde netto grasopbrengst (euro) } \\
\hline & \multirow[t]{2}{*}{ Productie } & & \multirow{2}{*}{$\begin{array}{l}\text { Verlaging door } \\
\mathrm{N} \text {-verlies }\end{array}$} & \multirow{2}{*}{$\begin{array}{l}\text { Voederwaarde } \\
(\%) \\
\end{array}$} & \multicolumn{2}{|c|}{ Rendement (\%) } & \multirow{2}{*}{$\begin{array}{l}\text { Aandeel } \\
\text { maaien (\%) }\end{array}$} & \multirow[t]{2}{*}{ VEM } & \multirow[t]{2}{*}{ DVE } & \multirow[t]{2}{*}{ KVEM } & \multirow[t]{2}{*}{$\overline{\text { KDVE }}$} & \multirow[t]{2}{*}{ KVEM } & \multirow[t]{2}{*}{ KDVE } & \multirow[t]{2}{*}{ Totaa } \\
\hline & & & & & weiden & maaien & & & & & & & & \\
\hline \multicolumn{15}{|c|}{56} \\
\hline 1 & & 7607 & & 100.0 & 83.0 & 85.0 & 84.1 & 987 & 101 & 6316 & 643 & 1074 & 624 & 1697 \\
\hline 2 & & 9520 & 152 & 99.7 & 82.7 & 84.8 & 83.9 & 984 & 100 & 7733 & 787 & 1315 & 764 & $207 \varepsilon$ \\
\hline 3 & & 9090 & 152 & 99.3 & 82.5 & 84.7 & 83.7 & 980 & 100 & 7334 & 747 & 1247 & 724 & 1971 \\
\hline 4 & & 8777 & 152 & 99.0 & 82.2 & 84.5 & 83.5 & 977 & 99 & 7036 & 716 & 1196 & 695 & 1891 \\
\hline 5 & & 8537 & 152 & 98.7 & 81.9 & 84.3 & 83.3 & 974 & 99 & 6800 & 692 & 1156 & 672 & $182 \varepsilon$ \\
\hline 6 & & 8344 & 152 & 98.3 & 81.7 & 84.2 & 83.1 & 971 & 99 & 6604 & 672 & 1123 & 652 & 1775 \\
\hline 7 & & 8183 & 152 & 98.0 & 81.4 & 84.0 & 82.9 & 967 & 98 & 6436 & 655 & 1094 & 636 & 1730 \\
\hline 8 & & 8043 & 152 & 97.7 & 81.1 & 83.8 & 82.6 & 964 & 98 & 6287 & 640 & 1069 & 621 & 1690 \\
\hline 9 & & 7921 & 152 & 97.3 & 80.9 & 83.7 & 82.4 & 961 & 98 & 6152 & 626 & 1046 & 608 & 1653 \\
\hline 10 & & 7811 & 152 & 97.0 & 80.6 & 83.5 & 82.2 & 957 & 97 & 6029 & 614 & 1025 & 595 & 1620 \\
\hline 11 & & 7711 & 152 & 96.7 & 80.3 & 83.3 & 82.0 & 954 & 97 & 5915 & 602 & 1005 & 584 & 1590 \\
\hline 12 & & 7620 & 152 & 96.3 & 80.1 & 83.2 & 81.8 & 951 & 97 & 5808 & 591 & 987 & 574 & 1561 \\
\hline 13 & & 7536 & 152 & 96.0 & 79.8 & 83.0 & 81.6 & 948 & 96 & 5709 & 581 & 970 & 564 & 1534 \\
\hline 14 & & 7459 & 152 & 95.7 & 79.5 & 82.8 & 81.4 & 944 & 96 & 5615 & 572 & 955 & 555 & $150 s$ \\
\hline 30 & & 6790 & & 90.0 & 75.0 & 80.0 & 77.8 & 888 & 90 & 4692 & 478 & 1101 & 639 & 1740 \\
\hline Gem & & 8154 & & 97.8 & 81.3 & 83.9 & 82.8 & 966 & 98 & 6412 & 653 & 1090 & 633 & 1723 \\
\hline
\end{tabular}


Tabel B6.4 Bruto grasopbrengst, opbrengstvermindering door stikstofverlies, verloop voederwaarde en rendement weiden en maaien, aandeel maaien, netto voederwaardeopbrengst en de waarde van de netto grasopbrengst voor het bodemtype Leemarm en droogtevariant Referentie gesimuleerd voor melkveeproefbedrijf De Marke bij herinzaai eens in de 14 jaar.

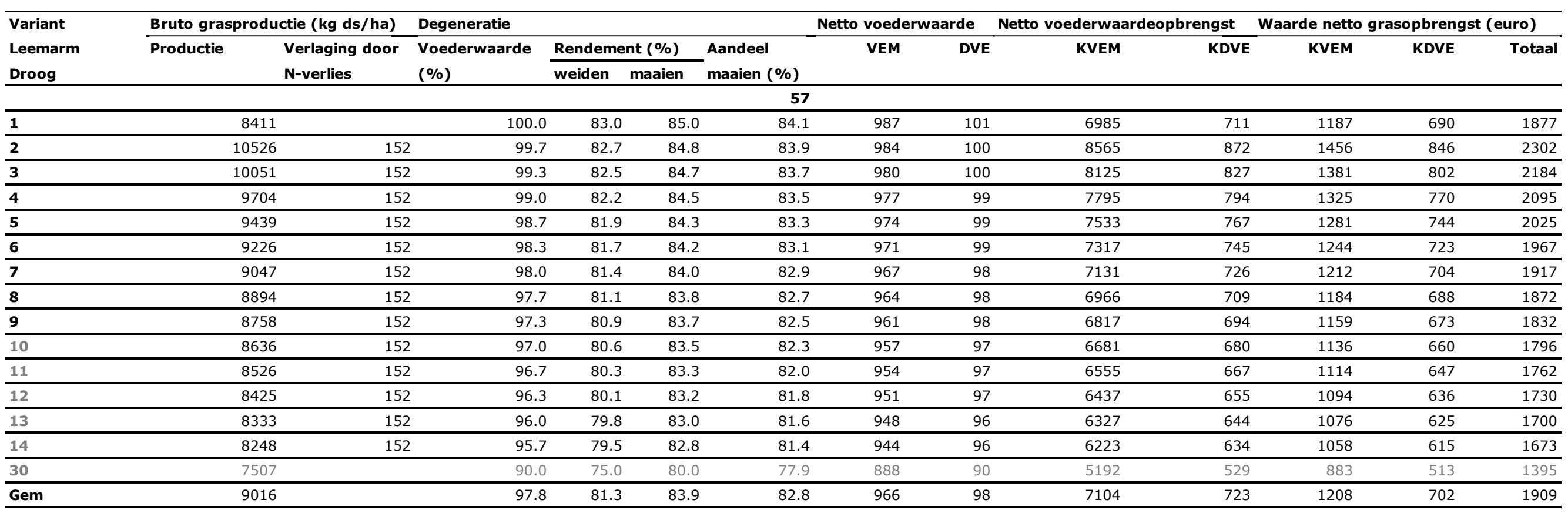


Tabel B6.5 Bruto grasopbrengst, opbrengstvermindering door stikstofverlies, verloop voederwaarde en rendement weiden en maaien, aandeel maaien, netto voederwaardeopbrengst en de waarde van de netto grasopbrengst voor het bodemtype Leemarm en droogtevariant Waterwinning 1 gesimuleerd voor melkveeproefbedrijf De Marke bij herinzaai eens in de 14 jaar.

\begin{tabular}{|c|c|c|c|c|c|c|c|c|c|c|c|c|c|c|}
\hline \multirow{3}{*}{$\begin{array}{l}\text { Variant } \\
\text { Leemarm } \\
\text { Waterwinning } 1\end{array}$} & \multicolumn{3}{|c|}{ Bruto grasproductie (kg ds/ha) } & \multicolumn{4}{|l|}{ Degeneratie } & \multicolumn{2}{|c|}{ Netto voederwaarde } & \multicolumn{2}{|c|}{ Netto voederwaardeopbrengst } & \multicolumn{3}{|c|}{ Waarde netto grasopbrengst (euro) } \\
\hline & \multirow{2}{*}{\multicolumn{2}{|c|}{ Productie }} & \multirow{2}{*}{$\begin{array}{l}\text { Verlaging door } \\
\mathrm{N} \text {-verlies }\end{array}$} & \multirow{2}{*}{$\begin{array}{l}\text { Voederwaarde } \\
(\%)\end{array}$} & \multicolumn{2}{|c|}{ Rendement (\%) } & \multirow{2}{*}{$\begin{array}{l}\text { Aandeel } \\
\text { maaien (\%) }\end{array}$} & \multirow[t]{2}{*}{ VEM } & \multirow[t]{2}{*}{ DVE } & \multirow[t]{2}{*}{ KVEM } & \multirow[t]{2}{*}{ KDVE } & \multirow[t]{2}{*}{ KVEM } & \multirow[t]{2}{*}{ KDVE } & \multirow[t]{2}{*}{ Totaa } \\
\hline & & & & & weiden & maaien & & & & & & & & \\
\hline \multicolumn{15}{|c|}{57} \\
\hline 1 & & 7447 & & 100.0 & 83.0 & 85.0 & 84.1 & 987 & 101 & 6185 & 630 & 1051 & 611 & 1662 \\
\hline 2 & & 9321 & 152 & 99.7 & 82.7 & 84.8 & 83.9 & 984 & 100 & 7570 & 771 & 1287 & 748 & 2034 \\
\hline 3 & & 8899 & 152 & 99.3 & 82.5 & 84.7 & 83.7 & 980 & 100 & 7180 & 731 & 1221 & 709 & 1930 \\
\hline 4 & & 8593 & 152 & 99.0 & 82.2 & 84.5 & 83.5 & 977 & 99 & 6887 & 701 & 1171 & 680 & 1851 \\
\hline 5 & & 8358 & 152 & 98.7 & 81.9 & 84.3 & 83.3 & 974 & 99 & 6656 & 678 & 1132 & 657 & 1789 \\
\hline 6 & & 8169 & 152 & 98.3 & 81.7 & 84.2 & 83.1 & 971 & 99 & 6465 & 658 & 1099 & 639 & 1738 \\
\hline 7 & & 8011 & 152 & 98.0 & 81.4 & 84.0 & 82.9 & 967 & 98 & 6300 & 642 & 1071 & 622 & 1693 \\
\hline 8 & & 7875 & 152 & 97.7 & 81.1 & 83.8 & 82.7 & 964 & 98 & 6154 & 627 & 1046 & 608 & 1654 \\
\hline 9 & & 7755 & 152 & 97.3 & 80.9 & 83.7 & 82.5 & 961 & 98 & 6022 & 613 & 1024 & 595 & 1619 \\
\hline 10 & & 7647 & 152 & 97.0 & 80.6 & 83.5 & 82.3 & 957 & 97 & 5902 & 601 & 1003 & 583 & 1586 \\
\hline 11 & & 7549 & 152 & 96.7 & 80.3 & 83.3 & 82.0 & 954 & 97 & 5790 & 590 & 984 & 572 & 1556 \\
\hline 12 & & 7460 & 152 & 96.3 & 80.1 & 83.2 & 81.8 & 951 & 97 & 5686 & 579 & 967 & 562 & 1528 \\
\hline 13 & & 7378 & 152 & 96.0 & 79.8 & 83.0 & 81.6 & 948 & 96 & 5589 & 569 & 950 & 552 & 1502 \\
\hline 14 & & 7303 & 152 & 95.7 & 79.5 & 82.8 & 81.4 & 944 & 96 & 5497 & 560 & 934 & 543 & 1477 \\
\hline 30 & & 6647 & & 90.0 & 75.0 & 80.0 & 77.9 & 888 & 90 & 4597 & 468 & 781 & 454 & 1235 \\
\hline Gem & & 7983 & & 97.8 & 81.3 & 83.9 & 82.8 & 966 & 98 & 6277 & 639 & 1067 & 620 & 1687 \\
\hline
\end{tabular}


Tabel B6.6 Bruto grasopbrengst, opbrengstvermindering door stikstofverlies, verloop voederwaarde en rendement weiden en maaien, aandeel maaien, netto voederwaardeopbrengst en de waarde van de netto grasopbrengst voor het bodemtype Leemarm en droogtevariant Waterwinning 2 gesimuleerd voor melkveeproefbedrijf De Marke bij herinzaai eens in de 14 jaar.

\begin{tabular}{|c|c|c|c|c|c|c|c|c|c|c|c|c|c|}
\hline \multirow{3}{*}{$\begin{array}{l}\text { Variant } \\
\text { Leemarm } \\
\text { Waterwinning } 2\end{array}$} & \multicolumn{2}{|c|}{ Bruto grasproductie (kg ds/ha) } & \multicolumn{4}{|l|}{ Degeneratie } & \multicolumn{2}{|c|}{ Netto voederwaarde } & \multicolumn{2}{|c|}{ Netto voederwaardeopbrengst } & \multicolumn{3}{|c|}{ Waarde netto grasopbrengst (euro) } \\
\hline & \multirow[t]{2}{*}{ Productie } & \multirow{2}{*}{$\begin{array}{l}\text { Verlaging door } \\
\mathrm{N} \text {-verlies }\end{array}$} & \multirow{2}{*}{$\begin{array}{l}\text { Voederwaarde } \\
(\%)\end{array}$} & \multicolumn{2}{|c|}{ Rendement (\%) } & \multirow{2}{*}{$\begin{array}{l}\text { Aandeel } \\
\text { maaien (\%) }\end{array}$} & \multirow[t]{2}{*}{ VEM } & \multirow[t]{2}{*}{ DVE } & \multirow[t]{2}{*}{ KVEM } & \multirow[t]{2}{*}{ KDVE } & \multirow[t]{2}{*}{ KVEM } & \multirow[t]{2}{*}{ KDVE } & \multirow[t]{2}{*}{ Totaal } \\
\hline & & & & weiden & maaien & & & & & & & & \\
\hline & & & & & & 57 & & & & & & & \\
\hline 1 & 7184 & & 100.0 & 83.0 & 85.0 & 84.1 & 987 & 101 & 5966 & 608 & 1014 & 589 & 1604 \\
\hline 2 & 8992 & 152 & 99.7 & 82.7 & 84.8 & 83.9 & 984 & 100 & 7298 & 743 & 1241 & 721 & 1961 \\
\hline 3 & 8585 & 152 & 99.3 & 82.5 & 84.7 & 83.7 & 980 & 100 & 6922 & 705 & 1177 & 684 & 1860 \\
\hline 4 & 8289 & 152 & 99.0 & 82.2 & 84.5 & 83.5 & 977 & 99 & 6640 & 676 & 1129 & 656 & 1785 \\
\hline 5 & 8063 & 152 & 98.7 & 81.9 & 84.3 & 83.3 & 974 & 99 & 6417 & 653 & 1091 & 634 & 1725 \\
\hline 6 & 7881 & 152 & 98.3 & 81.7 & 84.2 & 83.1 & 971 & 99 & 6232 & 635 & 1060 & 616 & 1675 \\
\hline 7 & 7728 & 152 & 98.0 & 81.4 & 84.0 & 82.9 & 967 & 98 & 6073 & 618 & 1032 & 600 & 1632 \\
\hline 8 & 7597 & 152 & 97.7 & 81.1 & 83.8 & 82.7 & 964 & 98 & 5933 & 604 & 1009 & 586 & 1595 \\
\hline 9 & 7481 & 152 & 97.3 & 80.9 & 83.7 & 82.5 & 961 & 98 & 5806 & 591 & 987 & 573 & 1560 \\
\hline 10 & 7377 & 152 & 97.0 & 80.6 & 83.5 & 82.3 & 957 & 97 & 5689 & 579 & 967 & 562 & 1529 \\
\hline 11 & 7283 & 152 & 96.7 & 80.3 & 83.3 & 82.0 & 954 & 97 & 5581 & 568 & 949 & 551 & 1500 \\
\hline 12 & 7197 & 152 & 96.3 & 80.1 & 83.2 & 81.8 & 951 & 97 & 5481 & 558 & 932 & 541 & 1473 \\
\hline 13 & 7118 & 152 & 96.0 & 79.8 & 83.0 & 81.6 & 948 & 96 & 5387 & 549 & 916 & 532 & 1448 \\
\hline 14 & 7045 & 152 & 95.7 & 79.5 & 82.8 & 81.4 & 944 & 96 & 5299 & 540 & 901 & 523 & 1424 \\
\hline 30 & 6413 & & 90.0 & 75.0 & 80.0 & 77.9 & 888 & 90 & 4435 & 452 & 754 & 438 & 1192 \\
\hline Gem & 7701 & & 97.8 & 81.3 & 83.9 & 82.8 & 966 & 98 & 6052 & 616 & 1029 & 598 & 1627 \\
\hline
\end{tabular}




\section{Bijlage 7 Invoer HerinzaaiWijzer bij verhoogde herzaaifrequentie}

Tabel B7.1 Invoer HerinzaaiWijzer berekening gemiddelde verandering in drogestofopbrengst van gras na herinzaai per droogtevariant per ha per jaar voor het bodemtype zwak lemig fijn zand.

\begin{tabular}{|c|c|c|c|}
\hline Uitgangspunten HerinzaaiWijzer & Referentie & Waterwinning 1 & Waterwinning 2 \\
\hline \multicolumn{4}{|l|}{ Algemeen } \\
\hline Herinzaai (\#/jaar) & 14 & 9 & 7 \\
\hline Fractie maaien (\%) & 55 & 56 & 56 \\
\hline Moment herinzaai in het jaar & najaar & najaar & najaar \\
\hline \multicolumn{4}{|l|}{ Voederwaarde } \\
\hline Voederwaarde (VEM en DVE) potentieel (\%) & 100 & 100 & 100 \\
\hline Voederwaarde lange termijn (\%) & 90 & 90 & 90 \\
\hline \multicolumn{4}{|l|}{ N-uitspoeling } \\
\hline $\mathrm{N}$-verlies (kg N/ha) & 180 & 180 & 180 \\
\hline Marginaal stikstofeffect $(\mathrm{kg} / \mathrm{kg} \mathrm{N})$ & 11 & 11 & 11 \\
\hline \multicolumn{4}{|l|}{ Rendement weiden } \\
\hline Potentieel rendement (\%) & 83 & 83 & 83 \\
\hline Rendement lange termijn (\%) & 75 & 75 & 75 \\
\hline \multicolumn{4}{|l|}{ Rendement maaien } \\
\hline Potentieel rendement (\%) & 85 & 85 & 85 \\
\hline Rendement lange termijn (\%) & 80 & 80 & 80 \\
\hline \multicolumn{4}{|l|}{ Productie } \\
\hline Berekende productie Waterpas & 10065 & 8871 & 8154 \\
\hline Productie lange termijn (\%) & 70 & 70 & 70 \\
\hline Extra productie jaar $1(\%)$ & 10 & 10 & 10 \\
\hline Verloop jaar 1-5 (\%/jaar) & 40 & 40 & 40 \\
\hline Verloop jaar 5-20 (\%/jaar) & 14,23 & 10,88 & 13,20 \\
\hline Verlies potentiële productie jaar 0 najaar (\%) & 25 & 25 & 25 \\
\hline
\end{tabular}


Tabel B7.2 Invoer HerinzaaiWijzer berekening gemiddelde verandering in drogestofopbrengst van gras na herinzaai per ha per jaar per droogtevariant voor het bodemtype leemarm fijn zand.

\begin{tabular}{|c|c|c|c|}
\hline Uitgangspunten HerinzaaiWijzer & Referentie & Waterwinning 1 & Waterwinning 2 \\
\hline \multicolumn{4}{|l|}{ Algemeen } \\
\hline Herinzaai (\#/jaar) & 9 & 7 & 6 \\
\hline Fractie maaien $(\%)$ & 57 & 57 & 57 \\
\hline Moment herinzaai in het jaar & najaar & najaar & najaar \\
\hline \multicolumn{4}{|l|}{ Voederwaarde } \\
\hline Voederwaarde (VEM en DVE) potentieel (\%) & 100 & 100 & 100 \\
\hline Voederwaarde lange termijn (\%) & 90 & 90 & 90 \\
\hline \multicolumn{4}{|l|}{ N-uitspoeling } \\
\hline N-verlies (kg N/ha) & 180 & 180 & 180 \\
\hline Marginaal stikstofeffect $(\mathrm{kg} / \mathrm{kg} \mathrm{N})$ & 11 & 11 & 11 \\
\hline \multicolumn{4}{|l|}{ Rendement weiden } \\
\hline Potentieel rendement (\%) & 83 & 83 & 83 \\
\hline Rendement lange termijn (\%) & 75 & 75 & 75 \\
\hline \multicolumn{4}{|l|}{ Rendement maaien } \\
\hline Potentieel rendement (\%) & 85 & 85 & 85 \\
\hline Rendement lange termijn (\%) & 80 & 80 & 80 \\
\hline \multicolumn{4}{|l|}{ Productie } \\
\hline Berekende productie Waterpas & 9016 & 7983 & 7701 \\
\hline Productie lange termijn (\%) & 70 & 70 & 70 \\
\hline Extra productie jaar $1(\%)$ & 10 & 10 & 10 \\
\hline Verloop jaar 1-5 (\%/jaar) & 40 & 40 & 40 \\
\hline Verloop jaar 5-20 (\%/jaar) & 10,88 & 13,20 & 14,70 \\
\hline Verlies potentiele productie jaar 0 najaar (\%) & 25 & 25 & 25 \\
\hline
\end{tabular}




\section{Bijlage 8 Grasopbrengstverloop bij verhoogde herzaaifrequentie}

Tabel B8.1 Bruto grasopbrengst, opbrengstvermindering door stikstofverlies, verloop voederwaarde en rendement weiden en maaien, aandeel maaien, netto voederwaardeopbrengst en de waarde van de netto grasopbrengst voor het bodemtype Zwak lemig en droogtevariant Referentie gesimuleerd voor melkveeproefbedrijf De Marke bij herinzaai eens in de 14 jaar.

\begin{tabular}{|c|c|c|c|c|c|c|c|c|c|c|c|c|c|}
\hline \multirow{3}{*}{$\begin{array}{l}\text { Variant } \\
\text { Zwak lemig } \\
\text { Droog }\end{array}$} & \multicolumn{2}{|c|}{ Bruto grasproductie (kg ds/ha) } & \multicolumn{4}{|l|}{ Degeneratie } & \multicolumn{2}{|c|}{ Netto voederwaarde } & \multicolumn{2}{|c|}{ Netto voederwaardeopbrengst } & \multicolumn{3}{|c|}{ Waarde netto grasopbrengst (euro) } \\
\hline & \multirow[t]{2}{*}{ Productie } & \multirow{2}{*}{$\begin{array}{l}\text { Verlaging door } \\
\mathrm{N} \text {-verlies }\end{array}$} & \multirow{2}{*}{$\begin{array}{l}\text { Voederwaarde } \\
(\%) \\
\end{array}$} & \multicolumn{2}{|c|}{ Rendement (\%) } & \multirow{2}{*}{$\begin{array}{l}\text { Aandeel } \\
\text { maaien }(\%)\end{array}$} & \multirow[t]{2}{*}{ VEM } & \multirow[t]{2}{*}{ DVE } & \multirow[t]{2}{*}{ KVEM } & \multirow[t]{2}{*}{ KDVE } & \multirow[t]{2}{*}{ KVEM } & \multirow[t]{2}{*}{ KDVE } & \multirow[t]{2}{*}{ Totaal } \\
\hline & & & & weiden & maaien & & & & & & & & \\
\hline & & & & & & 55 & & & & & & & \\
\hline 1 & 9389 & & 100.0 & 83.0 & 85.0 & 84.1 & 987 & 101 & 7794 & 794 & 1325 & 770 & 2095 \\
\hline 2 & 11751 & 152 & 99.7 & 82.7 & 84.8 & 83.9 & 984 & 100 & 9571 & 975 & 1627 & 945 & 2572 \\
\hline 3 & 11220 & 152 & 99.3 & 82.5 & 84.7 & 83.7 & 980 & 100 & 9080 & 925 & 1544 & 897 & 2440 \\
\hline 4 & 10833 & 152 & 99.0 & 82.2 & 84.5 & 83.5 & 977 & 99 & 8711 & 887 & 1481 & 860 & 2341 \\
\hline 5 & 10537 & 152 & 98.7 & 81.9 & 84.3 & 83.3 & 974 & 99 & 8419 & 857 & 1431 & 832 & 2263 \\
\hline 6 & 10299 & 152 & 98.3 & 81.7 & 84.2 & 83.0 & 971 & 99 & 8178 & 833 & 1390 & 808 & 2198 \\
\hline 7 & 10100 & 152 & 98.0 & 81.4 & 84.0 & 82.8 & 967 & 98 & 7970 & 812 & 1355 & 787 & 2142 \\
\hline 8 & 9928 & 152 & 97.7 & 81.1 & 83.8 & 82.6 & 964 & 98 & 7786 & 793 & 1324 & 769 & 2093 \\
\hline 9 & 9777 & 152 & 97.3 & 80.9 & 83.7 & 82.4 & 961 & 98 & 7619 & 776 & 1295 & 753 & 2048 \\
\hline 10 & 9641 & 152 & 97.0 & 80.6 & 83.5 & 82.2 & 957 & 97 & 7467 & 760 & 1269 & 737 & 2007 \\
\hline 11 & 9518 & 152 & 96.7 & 80.3 & 83.3 & 82.0 & 954 & 97 & 7326 & 746 & 1245 & 724 & 1969 \\
\hline 12 & 9405 & 152 & 96.3 & 80.1 & 83.2 & 81.8 & 951 & 97 & 7194 & 733 & 1223 & 711 & 1934 \\
\hline 13 & 9302 & 152 & 96.0 & 79.8 & 83.0 & 81.6 & 948 & 96 & 7071 & 720 & 1202 & 698 & 1900 \\
\hline 14 & 9207 & 152 & 95.7 & 79.5 & 82.8 & 81.3 & 944 & 96 & 6955 & 708 & 1182 & 687 & 1869 \\
\hline 30 & 8381 & & 90.0 & 75.0 & 80.0 & 77.8 & 888 & 90 & 5788 & 589 & 984 & 572 & 1556 \\
\hline Gem & 10065 & 152 & 97.8 & 81.3 & 83.9 & 82.7 & 966 & 98 & 7939 & 808 & 1350 & 784 & 2134 \\
\hline
\end{tabular}


Tabel B8.2 Bruto grasopbrengst, opbrengstvermindering door stikstofverlies, verloop voederwaarde en rendement weiden en maaien, aandeel maaien, netto voederwaardeopbrengst en de waarde van de netto grasopbrengst voor het bodemtype Zwak lemig en droogtevariant Waterwinning 1 gesimuleerd voor melkveeproefbedrijf De Marke bij herinzaai eens in de 10 jaar.

\begin{tabular}{|c|c|c|c|c|c|c|c|c|c|c|c|c|c|}
\hline \multirow{3}{*}{$\begin{array}{l}\text { Variant } \\
\text { Zwak lemig } \\
\text { Waterwinning } 1 \\
\end{array}$} & \multicolumn{2}{|c|}{ Bruto grasproductie (kg ds/ha) } & \multicolumn{4}{|l|}{ Degeneratie } & \multicolumn{2}{|c|}{ Netto voederwaarde } & \multicolumn{2}{|c|}{ Netto voederwaardeopbrengst } & \multicolumn{3}{|c|}{ Waarde netto grasopbrengst (euro) } \\
\hline & \multirow[t]{2}{*}{ Productie } & \multirow{2}{*}{$\begin{array}{l}\text { Verlaging door } \\
\mathrm{N} \text {-verlies }\end{array}$} & \multirow{2}{*}{$\begin{array}{l}\text { Voederwaarde } \\
(\%) \\
\end{array}$} & \multicolumn{2}{|c|}{ Rendement (\%) } & \multirow{2}{*}{$\begin{array}{l}\text { Aandeel } \\
\text { maaien (\%) }\end{array}$} & \multirow[t]{2}{*}{ VEM } & \multirow[t]{2}{*}{ DVE } & \multirow[t]{2}{*}{ KVEM } & \multirow[t]{2}{*}{ KDVE } & \multirow[t]{2}{*}{ KVEM } & \multirow[t]{2}{*}{ KDVE } & \multirow[t]{2}{*}{ Totaa } \\
\hline & & & & weiden & maaien & & & & & & & & \\
\hline & & & & & & 56 & & & & & & & \\
\hline 1 & 8190 & & 100.0 & 83.0 & 85.0 & 83.3 & 987 & 101 & 6731 & 685 & 1144 & 665 & 1809 \\
\hline 2 & 10158 & 248 & 99.7 & 82.7 & 84.8 & 83.1 & 984 & 100 & 8098 & 825 & 1377 & 800 & 2176 \\
\hline 3 & 9625 & 248 & 99.3 & 82.5 & 84.7 & 82.9 & 980 & 100 & 7617 & 776 & 1295 & 752 & 2047 \\
\hline 4 & 9233 & 248 & 99.0 & 82.2 & 84.5 & 82.6 & 977 & 99 & 7256 & 739 & 1234 & 717 & 1950 \\
\hline 5 & 8933 & 248 & 98.7 & 81.9 & 84.3 & 82.4 & 974 & 99 & 6972 & 710 & 1185 & 689 & 1874 \\
\hline 6 & 8693 & 248 & 98.3 & 81.7 & 84.2 & 82.2 & 971 & 99 & 6740 & 686 & 1146 & 666 & 1811 \\
\hline 7 & 8496 & 248 & 98.0 & 81.4 & 84.0 & 82.0 & 967 & 98 & 6544 & 666 & 1112 & 646 & 1759 \\
\hline 8 & 8330 & 248 & 97.7 & 81.1 & 83.8 & 81.8 & 964 & 98 & 6374 & 649 & 1084 & 630 & 1713 \\
\hline 9 & 8187 & 248 & 97.3 & 80.9 & 83.7 & 81.6 & 961 & 98 & 6224 & 634 & 1058 & 615 & 1673 \\
\hline 10 & 8064 & 220 & 97.0 & 80.6 & 83.5 & 81.4 & 957 & 97 & 6112 & 622 & 1039 & 604 & 1643 \\
\hline 11 & 7955 & & 96.7 & 80.3 & 83.3 & 81.2 & 954 & 97 & 6162 & 627 & 1047 & 609 & 1656 \\
\hline 12 & 7860 & & 96.3 & 80.1 & 83.2 & 81.0 & 951 & 97 & 6051 & 616 & 1029 & 598 & 1626 \\
\hline 13 & 7776 & & 96.0 & 79.8 & 83.0 & 80.8 & 948 & 96 & 5950 & 606 & 1012 & 588 & 1599 \\
\hline 14 & 7701 & & 95.7 & 79.5 & 82.8 & 80.6 & 944 & 96 & 5857 & 596 & 996 & 579 & 1574 \\
\hline 30 & 7190 & & 90.0 & 75.0 & 80.0 & 77.0 & 888 & 90 & 4918 & 501 & 836 & 486 & 1322 \\
\hline Gem & 8872 & 248 & 98.7 & 81.9 & 84.3 & 82.4 & 974 & 99 & 6951 & 708 & 1182 & 687 & 1868 \\
\hline
\end{tabular}


Tabel B8.3 Bruto grasopbrengst, opbrengstvermindering door stikstofverlies, verloop voederwaarde en rendement weiden en maaien, aandeel maaien, netto voederwaardeopbrengst en de waarde van de netto grasopbrengst voor het bodemtype Zwak lemig en droogtevariant Waterwinning 2 gesimuleerd voor melkveeproefbedrijf De Marke bij herinzaai eens in de 8 jaar.

\begin{tabular}{|c|c|c|c|c|c|c|c|c|c|c|c|c|c|c|}
\hline \multirow{3}{*}{$\begin{array}{l}\text { Variant } \\
\text { Zwak lemig } \\
\text { Waterwinning } 2\end{array}$} & \multicolumn{3}{|c|}{ Bruto grasproductie (kg ds/ha) } & \multicolumn{4}{|l|}{ Degeneratie } & \multicolumn{2}{|c|}{ Netto voederwaarde } & \multicolumn{2}{|c|}{ Netto voederwaardeopbrengst } & \multicolumn{3}{|c|}{ Waarde netto grasopbrengst (euro) } \\
\hline & \multirow{2}{*}{\multicolumn{2}{|c|}{ Productie }} & \multirow{2}{*}{$\begin{array}{l}\text { Verlaging door } \\
\mathrm{N} \text {-verlies }\end{array}$} & \multirow{2}{*}{$\begin{array}{l}\text { Voederwaarde } \\
(\%) \\
\end{array}$} & \multicolumn{2}{|c|}{ Rendement (\%) } & \multirow{2}{*}{$\begin{array}{l}\text { Aandeel } \\
\text { maaien (\%) }\end{array}$} & \multirow[t]{2}{*}{ VEM } & \multirow[t]{2}{*}{ DVE } & \multirow[t]{2}{*}{ KVEM } & \multirow[t]{2}{*}{ KDVE } & \multirow[t]{2}{*}{ KVEM } & \multirow[t]{2}{*}{ KDVE } & \multirow[t]{2}{*}{ Totaal } \\
\hline & & & & & weiden & maaien & & & & & & & & \\
\hline \multicolumn{15}{|c|}{56} \\
\hline 1 & & 7474 & & 100.0 & 83.0 & 85.0 & 83.3 & 987 & 101 & 6142 & 625 & 1044 & 607 & 1651 \\
\hline 2 & & 9215 & 330 & 99.7 & 82.7 & 84.8 & 83.1 & 984 & 100 & 7260 & 739 & 1234 & 717 & 1951 \\
\hline 3 & & 8690 & 330 & 99.3 & 82.5 & 84.7 & 82.9 & 980 & 100 & 6791 & 691 & 1154 & 671 & 1825 \\
\hline 4 & & 8306 & 330 & 99.0 & 82.2 & 84.5 & 82.6 & 977 & 99 & 6441 & 656 & 1095 & 636 & 1731 \\
\hline 5 & & 8014 & 330 & 98.7 & 81.9 & 84.3 & 82.4 & 974 & 99 & 6168 & 628 & 1049 & 609 & 1658 \\
\hline 6 & & 7784 & 330 & 98.3 & 81.7 & 84.2 & 82.2 & 971 & 99 & 5948 & 606 & 1011 & 588 & 1599 \\
\hline 7 & & 7598 & 330 & 98.0 & 81.4 & 84.0 & 82.0 & 967 & 98 & 5766 & 587 & 980 & 569 & 1550 \\
\hline 8 & & 7444 & 330 & 97.7 & 81.1 & 83.8 & 81.8 & 964 & 98 & 5610 & 571 & 954 & 554 & 1508 \\
\hline 9 & & 7316 & & 97.3 & 80.9 & 83.7 & 81.6 & 961 & 98 & 5735 & 584 & 975 & 566 & 1541 \\
\hline 10 & & 7207 & & 97.0 & 80.6 & 83.5 & 81.4 & 957 & 97 & 5616 & 572 & 955 & 555 & 1509 \\
\hline 11 & & 7114 & & 96.7 & 80.3 & 83.3 & 81.2 & 954 & 97 & 5510 & 561 & 937 & 544 & 1481 \\
\hline 12 & & 7034 & & 96.3 & 80.1 & 83.2 & 81.0 & 951 & 97 & 5416 & 551 & 921 & 535 & 1456 \\
\hline 13 & & 6966 & & 96.0 & 79.8 & 83.0 & 80.8 & 948 & 96 & 5330 & 543 & 906 & 526 & 1433 \\
\hline 14 & & 6906 & & 95.7 & 79.5 & 82.8 & 80.6 & 944 & 96 & 5253 & 535 & 893 & 519 & 1412 \\
\hline 30 & & 6560 & & 90.0 & 75.0 & 80.0 & 77.0 & 888 & 90 & 4487 & 457 & 1055 & 613 & 1668 \\
\hline Gem & & 8154 & 330 & 99.0 & 82.2 & 84.5 & 82.6 & 977 & 99 & 6359 & 648 & 1081 & 628 & 1709 \\
\hline
\end{tabular}


Tabel B8.4 Bruto grasopbrengst, opbrengstvermindering door stikstofverlies, verloop voederwaarde en rendement weiden en maaien, aandeel maaien, netto voederwaardeopbrengst en de waarde van de netto grasopbrengst voor het bodemtype Leemarm en droogtevariant Referentie gesimuleerd voor melkveeproefbedrijf De Marke bij herinzaai eens in de 10 jaar.

\begin{tabular}{|c|c|c|c|c|c|c|c|c|c|c|c|c|c|}
\hline \multirow{3}{*}{$\begin{array}{l}\text { Variant } \\
\text { Leemarm } \\
\text { Droog }\end{array}$} & \multicolumn{2}{|c|}{ Bruto grasproductie (kg ds/ha) } & \multicolumn{4}{|l|}{ Degeneratie } & \multicolumn{2}{|c|}{ Netto voederwaarde } & \multicolumn{2}{|c|}{ Netto voederwaardeopbrengst } & \multicolumn{3}{|c|}{ Waarde netto grasopbrengst (euro) } \\
\hline & \multirow[t]{2}{*}{ Productie } & \multirow{2}{*}{$\begin{array}{l}\text { Verlaging door } \\
\mathrm{N} \text {-verlies }\end{array}$} & \multirow{2}{*}{$\begin{array}{l}\text { Voederwaarde } \\
(\%) \\
\end{array}$} & \multicolumn{2}{|c|}{ Rendement (\%) } & \multirow{2}{*}{$\begin{array}{l}\text { Aandeel } \\
\text { maaien (\%) }\end{array}$} & \multirow[t]{2}{*}{ VEM } & \multirow[t]{2}{*}{ DVE } & \multirow[t]{2}{*}{ KVEM } & \multirow[t]{2}{*}{ KDVE } & \multirow[t]{2}{*}{ KVEM } & \multirow[t]{2}{*}{ KDVE } & \multirow[t]{2}{*}{ Totaa } \\
\hline & & & & weiden & maaien & & & & & & & & \\
\hline & & & & & & 57 & & & & & & & \\
\hline 1 & 8323 & & 100.0 & 83.0 & 85.0 & 82.4 & 987 & 101 & 6773 & 690 & 1151 & 669 & 1820 \\
\hline 2 & 10324 & 248 & 99.7 & 82.7 & 84.8 & 82.2 & 984 & 100 & 8151 & 830 & 1386 & 805 & 2191 \\
\hline 3 & 9782 & 248 & 99.3 & 82.5 & 84.7 & 82.0 & 980 & 100 & 7667 & 781 & 1303 & 757 & 2061 \\
\hline 4 & 9384 & 248 & 99.0 & 82.2 & 84.5 & 81.8 & 977 & 99 & 7304 & 744 & 1242 & 721 & 1963 \\
\hline 5 & 9078 & 248 & 98.7 & 81.9 & 84.3 & 81.6 & 974 & 99 & 7019 & 715 & 1193 & 693 & 1886 \\
\hline 6 & 8835 & 248 & 98.3 & 81.7 & 84.2 & 81.4 & 971 & 99 & 6785 & 691 & 1153 & 670 & 1824 \\
\hline 7 & 8634 & 248 & 98.0 & 81.4 & 84.0 & 81.2 & 967 & 98 & 6587 & 671 & 1120 & 651 & 1770 \\
\hline 8 & 8466 & 248 & 97.7 & 81.1 & 83.8 & 81.0 & 964 & 98 & 6417 & 653 & 1091 & 634 & 1725 \\
\hline 9 & 8321 & 248 & 97.3 & 80.9 & 83.7 & 80.8 & 961 & 98 & 6266 & 638 & 1065 & 619 & 1684 \\
\hline 10 & 8195 & 220 & 97.0 & 80.6 & 83.5 & 80.6 & 957 & 97 & 6153 & 626 & 1046 & 608 & 1654 \\
\hline 11 & 8085 & & 96.7 & 80.3 & 83.3 & 80.4 & 954 & 97 & 6200 & 631 & 1054 & 612 & 1666 \\
\hline 12 & 7988 & & 96.3 & 80.1 & 83.2 & 80.2 & 951 & 97 & 6089 & 620 & 1035 & 601 & 1637 \\
\hline 13 & 7902 & & 96.0 & 79.8 & 83.0 & 80.0 & 948 & 96 & 5987 & 610 & 1018 & 591 & 1609 \\
\hline 14 & 7826 & & 95.7 & 79.5 & 82.8 & 79.8 & 944 & 96 & 5894 & 600 & 1002 & 582 & 1584 \\
\hline 30 & 7307 & & 90.0 & 75.0 & 80.0 & 76.3 & 888 & 90 & 4949 & 504 & 841 & 489 & 1330 \\
\hline Gem & 9016 & 248 & 98.7 & 81.9 & 84.3 & 81.6 & 974 & 99 & 6997 & 712 & 1189 & 691 & 1880 \\
\hline
\end{tabular}


Tabel B8.5 Bruto grasopbrengst, opbrengstvermindering door stikstofverlies, verloop voederwaarde en rendement weiden en maaien, aandeel maaien, netto voederwaardeopbrengst en de waarde van de netto grasopbrengst voor het bodemtype Leemarm en droogtevariant Waterwinning 1 gesimuleerd voor melkveeproefbedrijf De Marke bij herinzaai eens in de 7 jaar.

\begin{tabular}{|c|c|c|c|c|c|c|c|c|c|c|c|c|c|c|}
\hline \multirow{3}{*}{$\begin{array}{l}\text { Variant } \\
\text { Leemarm } \\
\text { Waterwinning } 1 \\
\end{array}$} & \multicolumn{3}{|c|}{ Bruto grasproductie (kg ds/ha) } & \multicolumn{4}{|l|}{ Degeneratie } & \multicolumn{2}{|c|}{ Netto voederwaarde } & \multicolumn{2}{|c|}{ Netto voederwaardeopbrengst } & \multicolumn{3}{|c|}{ Waarde netto grasopbrengst (euro) } \\
\hline & \multirow{2}{*}{\multicolumn{2}{|c|}{ Productie }} & \multirow{2}{*}{$\begin{array}{l}\text { Verlaging door } \\
\mathrm{N} \text {-verlies }\end{array}$} & \multirow{2}{*}{$\begin{array}{l}\text { Voederwaarde } \\
(\%)\end{array}$} & \multicolumn{2}{|c|}{ Rendement (\%) } & \multirow{2}{*}{$\begin{array}{l}\text { Aandeel } \\
\text { maaien (\%) }\end{array}$} & \multirow[t]{2}{*}{ VEM } & \multirow[t]{2}{*}{ DVE } & \multirow[t]{2}{*}{ KVEM } & \multirow[t]{2}{*}{ KDVE } & \multirow[t]{2}{*}{ KVEM } & \multirow[t]{2}{*}{ KDVE } & \multirow[t]{2}{*}{ Totaa } \\
\hline & & & & & weiden & maaien & & & & & & & & \\
\hline \multicolumn{15}{|c|}{57} \\
\hline 1 & & 7317 & & 100.0 & 83.0 & 85.0 & 82.4 & 987 & 101 & 5954 & 606 & 1012 & 588 & 1600 \\
\hline 2 & & 9022 & 330 & 99.7 & 82.7 & 84.8 & 82.2 & 984 & 100 & 7031 & 716 & 1195 & 694 & 1890 \\
\hline 3 & & 8508 & 330 & 99.3 & 82.5 & 84.7 & 82.0 & 980 & 100 & 6577 & 670 & 1118 & 650 & 1768 \\
\hline 4 & & 8132 & 330 & 99.0 & 82.2 & 84.5 & 81.8 & 977 & 99 & 6237 & 635 & 1060 & 616 & 1676 \\
\hline 5 & & 7846 & 330 & 98.7 & 81.9 & 84.3 & 81.6 & 974 & 99 & 5973 & 608 & 1015 & 590 & 1605 \\
\hline 6 & & 7620 & 330 & 98.3 & 81.7 & 84.2 & 81.4 & 971 & 99 & 5760 & 587 & 979 & 569 & 1548 \\
\hline 7 & & 7438 & 330 & 98.0 & 81.4 & 84.0 & 81.2 & 967 & 98 & 5583 & 568 & 949 & 551 & 1501 \\
\hline 8 & & 7288 & & 97.7 & 81.1 & 83.8 & 81.0 & 964 & 98 & 5690 & 579 & 967 & 562 & 1529 \\
\hline 9 & & 7162 & & 97.3 & 80.9 & 83.7 & 80.8 & 961 & 98 & 5559 & 566 & 945 & 549 & 1494 \\
\hline 10 & & 7056 & & 97.0 & 80.6 & 83.5 & 80.6 & 957 & 97 & 5443 & 554 & 925 & 538 & 1463 \\
\hline 11 & & 6965 & & 96.7 & 80.3 & 83.3 & 80.4 & 954 & 97 & 5341 & 544 & 908 & 528 & 1436 \\
\hline 12 & & 6887 & & 96.3 & 80.1 & 83.2 & 80.2 & 951 & 97 & 5249 & 535 & 892 & 518 & 1411 \\
\hline 13 & & 6819 & & 96.0 & 79.8 & 83.0 & 80.0 & 948 & 96 & 5167 & 526 & 878 & 510 & 1389 \\
\hline 14 & & 6761 & & 95.7 & 79.5 & 82.8 & 79.8 & 944 & 96 & 5092 & 518 & 866 & 503 & 1369 \\
\hline 30 & & 6423 & & 90.0 & 75.0 & 80.0 & 76.3 & 888 & 90 & 4350 & 443 & 740 & 430 & 1169 \\
\hline Gem & & 7983 & 330 & 99.0 & 82.2 & 84.5 & 81.8 & 977 & 99 & 6159 & 627 & 1047 & 608 & 1655 \\
\hline
\end{tabular}


Tabel B8.6 Bruto grasopbrengst, opbrengstvermindering door stikstofverlies, verloop voederwaarde en rendement weiden en maaien, aandeel maaien, netto voederwaardeopbrengst en de waarde van de netto grasopbrengst voor het bodemtype Leemarm en droogtevariant Waterwinning 2 gesimuleerd voor melkveeproefbedrijf De Marke bij herinzaai eens in de 6 jaar.

\begin{tabular}{|c|c|c|c|c|c|c|c|c|c|c|c|c|c|c|}
\hline \multirow{3}{*}{$\begin{array}{l}\text { Variant } \\
\text { Leemarm } \\
\text { Waterwinning } 2 \\
\end{array}$} & \multicolumn{3}{|c|}{ Bruto grasproductie (kg ds/ha) } & \multicolumn{4}{|l|}{ Degeneratie } & \multicolumn{2}{|c|}{ Netto voederwaarde } & \multicolumn{2}{|c|}{ Netto voederwaardeopbrengst } & \multicolumn{3}{|c|}{ Waarde netto grasopbrengst (euro) } \\
\hline & \multirow{2}{*}{\multicolumn{2}{|c|}{ Productie }} & \multirow{2}{*}{$\begin{array}{l}\text { Verlaging door } \\
\mathrm{N} \text {-verlies }\end{array}$} & \multirow{2}{*}{$\begin{array}{l}\text { Voederwaarde } \\
(\%)\end{array}$} & \multicolumn{2}{|c|}{ Rendement (\%) } & \multirow{2}{*}{$\begin{array}{l}\text { Aandeel } \\
\text { maaien (\%) }\end{array}$} & \multirow[t]{2}{*}{ VEM } & \multirow[t]{2}{*}{ DVE } & \multirow[t]{2}{*}{ KVEM } & \multirow[t]{2}{*}{ KDVE } & \multirow[t]{2}{*}{ KVEM } & \multirow[t]{2}{*}{ KDVE } & \multirow[t]{2}{*}{ Totaal } \\
\hline & & & & & weiden & maaien & & & & & & & & \\
\hline \multicolumn{15}{|c|}{57} \\
\hline 1 & & 7026 & & 100.0 & 83.0 & 85.0 & 82.4 & 987 & 101 & 5717 & 582 & 972 & 565 & 1536 \\
\hline 2 & & 8631 & 396 & 99.7 & 82.7 & 84.8 & 82.2 & 984 & 100 & 6661 & 678 & 1132 & 658 & 1790 \\
\hline 3 & & 8116 & 396 & 99.3 & 82.5 & 84.7 & 82.0 & 980 & 100 & 6208 & 632 & 1055 & 613 & 1669 \\
\hline 4 & & 7741 & 396 & 99.0 & 82.2 & 84.5 & 81.8 & 977 & 99 & 5873 & 598 & 998 & 580 & 1578 \\
\hline 5 & & 7458 & 396 & 98.7 & 81.9 & 84.3 & 81.6 & 974 & 99 & 5613 & 572 & 954 & 554 & 1509 \\
\hline 6 & & 7238 & 396 & 98.3 & 81.7 & 84.2 & 81.4 & 971 & 99 & 5406 & 550 & 919 & 534 & 1453 \\
\hline 7 & & 7063 & 396 & 98.0 & 81.4 & 84.0 & 81.2 & 967 & 98 & 5236 & 533 & 890 & 517 & 1407 \\
\hline 8 & & 6920 & & 97.7 & 81.1 & 83.8 & 81.0 & 964 & 98 & 5403 & 550 & 918 & 534 & 1452 \\
\hline 9 & & 6802 & & 97.3 & 80.9 & 83.7 & 80.8 & 961 & 98 & 5279 & 538 & 897 & 521 & 1419 \\
\hline 10 & & 6704 & & 97.0 & 80.6 & 83.5 & 80.6 & 957 & 97 & 5172 & 527 & 879 & 511 & 1390 \\
\hline 11 & & 6622 & & 96.7 & 80.3 & 83.3 & 80.4 & 954 & 97 & 5078 & 517 & 863 & 502 & 1365 \\
\hline 12 & & 6552 & & 96.3 & 80.1 & 83.2 & 80.2 & 951 & 97 & 4995 & 509 & 849 & 493 & 1342 \\
\hline 13 & & 6494 & & 96.0 & 79.8 & 83.0 & 80.0 & 948 & 96 & 4920 & 501 & 836 & 486 & 1322 \\
\hline 14 & & 6444 & & 95.7 & 79.5 & 82.8 & 79.8 & 944 & 96 & 4853 & 494 & 825 & 479 & 1304 \\
\hline 30 & & 6181 & & 90.0 & 75.0 & 80.0 & 76.3 & 888 & 90 & 4186 & 426 & 712 & 413 & 1125 \\
\hline Gem & & 7702 & 396 & 99.2 & 82.3 & 84.6 & 81.9 & 979 & 100 & 5913 & 602 & 1005 & 584 & 1589 \\
\hline
\end{tabular}




\section{Bijlage 9 Kosten herinzaai}

Tabel B9.1 Kosten herinzaai grasland per ha voor zand-en kleigrond in euro per ha (KWIN, 2020).

\begin{tabular}{|c|c|c|}
\hline \multirow[t]{2}{*}{ Omschrijving } & \multicolumn{2}{|c|}{ Kosten per ha (C) } \\
\hline & Zandgronden & Kleigronden \\
\hline \multicolumn{3}{|l|}{ Herinzaai } \\
\hline${\text { Grondonderzoek (basis) }{ }^{1)}}$ & 45 & 45 \\
\hline \multicolumn{3}{|l|}{ Middelen } \\
\hline - $\quad 4$ liter glyfosaat/ha $(360 \mathrm{~g} / \mathrm{l})$ & 24 & 24 \\
\hline - $\quad$ onkruidbestrijdingsmiddelen ${ }^{2)}$ & 34 & 34 \\
\hline - $\quad$ zaaizaad (35 kg BG4) ${ }^{3)}$ & 198 & 198 \\
\hline \multirow[t]{2}{*}{$\begin{array}{ll}\text { - } \quad \text { startgift } 30 \mathrm{~kg} \mathrm{~N} / \mathrm{ha} \\
\end{array}$} & 29 & 29 \\
\hline & 330 & 330 \\
\hline \multicolumn{3}{|l|}{ Loonwerk } \\
\hline - $\quad$ spuiten glyfosaat & 40 & 40 \\
\hline - $\quad$ spuiten tegen onkruid & 40 & 40 \\
\hline - $\quad$ frezen $(5 \mathrm{~cm})$ & 102 & 137 \\
\hline - ploegen & 134 & 149 \\
\hline \multirow[t]{2}{*}{ - $\quad$ inzaai met zaaicombinatie ${ }^{4)}$} & 102 & 120 \\
\hline & 418 & 489 \\
\hline \multicolumn{3}{|l|}{ Aanvullende bemesting bij bemestingstoestand 'laag' } \\
\hline - $\quad$ natrium, koper, kobalt (kleigrond geen kobalt) & 176 & 91 \\
\hline - $\quad$ kalk en magnesium (kleigrond geen magnesium) & 378 & 214 \\
\hline \multirow[t]{2}{*}{ - $\quad$ kalium en fosfaat } & 85 & 95 \\
\hline & 639 & 400 \\
\hline 2 uur egaliseren met kilverbak + laser & 249 & 249 \\
\hline \multicolumn{3}{|l|}{ Totaal } \\
\hline - $\quad$ standaard inzaaimethode & 750 & 819 \\
\hline - $\quad$ inzaai met extra bemesting & 1389 & 1219 \\
\hline - $\quad$ inzaai met extra bemesting en kilveren & 1638 & 1468 \\
\hline
\end{tabular}

1) Op basis van kosten grondonderzoek (basis) en 2 ha per monster

2) Gebaseerd op $90 \mathrm{ml}$ Primus of 0,6 L Starane per ha, tegen breedbladige onkruiden

3) Graszaadmengsel met klaver $€ 210$,-

4) Zaaicombinatie betreft in één werkgang zaaibedbereiding (bijvoorbeeld roterkopeg) en inzaai met zaaimachine 


\section{Bijlage 10 Kosten extra herinzaai bij vervroegde GXG}

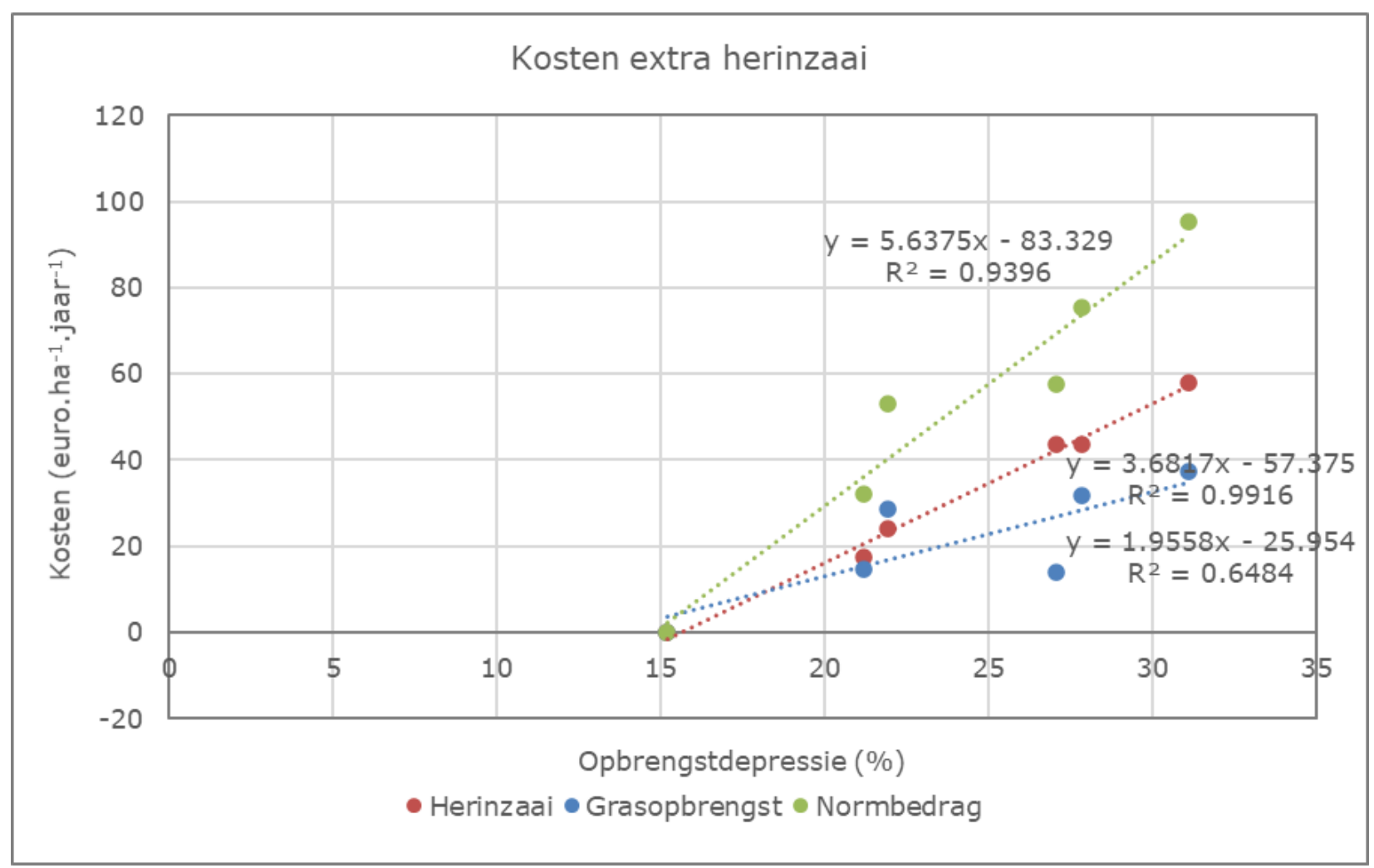

Figuur B10.1. Kosten extra herinzaai (euro.ha-1.jaar-1) door waterwinning op een relatief droge zandgrond in relatie tot de opbrengstdepressie voor grasland, met onderscheid tussen de directe kosten voor herinzaai, het waardeverlies van de netto grasopbrengst en de normbedragen als totaal hiervan bij een vervroeging van de GHG en GLG van ongeveer anderhalve maand (respectievelijk eind februari en begin september). Voor de normbedragen staat de functie vermeld. 

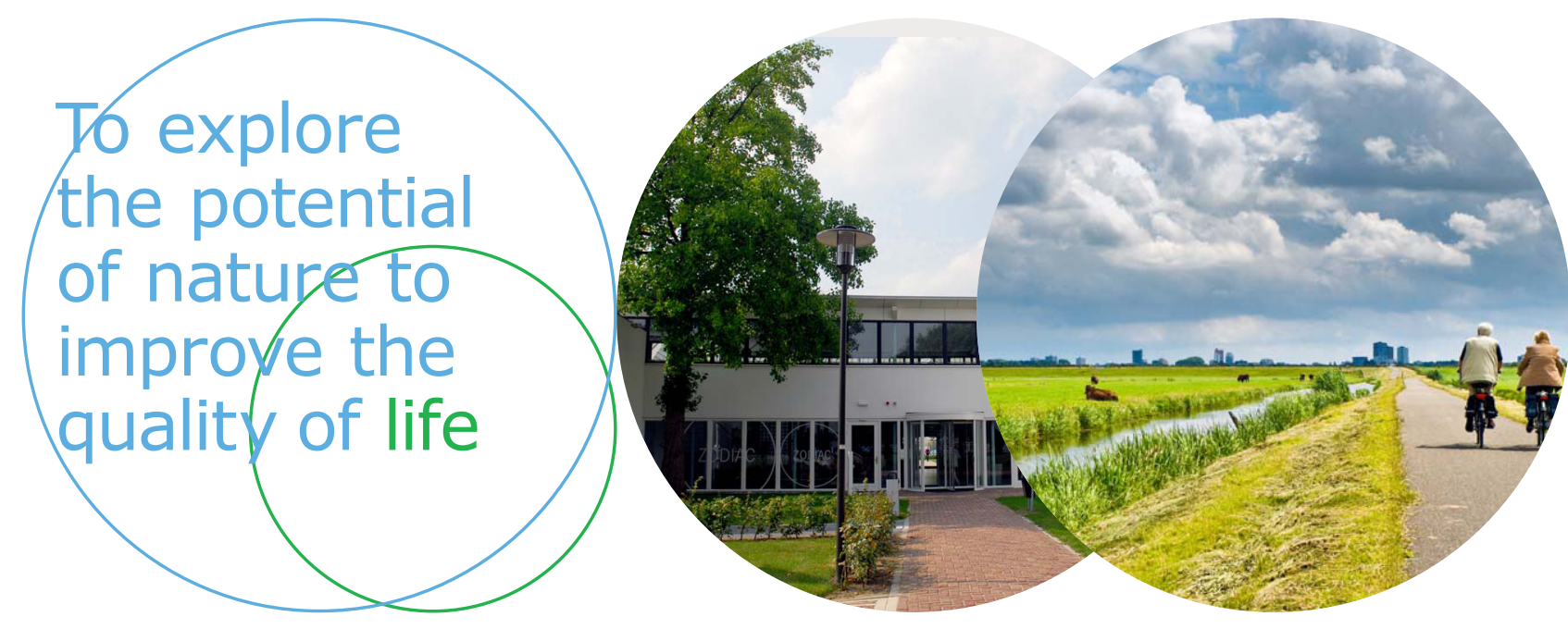

Wageningen Livestock Research Postbus 338

$6700 \mathrm{AH}$ Wageningen

T 0317483953

E info.livestockresearch@wur.nl www.wur.nl/livestock-research
Wageningen Livestock Research ontwikkelt kennis voor een zorgvuldige en renderende veehouderij, vertaalt deze naar praktijkgerichte oplossingen en innovaties, en zorgt voor doorstroming van deze kennis. Onze wetenschappelijke kennis op het gebied van veehouderijsystemen en van voeding, genetica, welzijn en milieu-impact van landbouwhuisdieren integreren we, samen met onze klanten, tot veehouderijconcepten voor de $21 \mathrm{e}$ eeuw.

De missie van Wageningen University \& Research is 'To explore the potential of nature to improve the quality of life'. Binnen Wageningen University \& Research bundelen 9 gespecialiseerde onderzoeksinstituten van Stichting Wageningen Research en Wageningen University hun krachten om bij te dragen aan de oplossing van belangrijke vragen in het domein van gezonde voeding en leefomgeving. Met ongeveer 30 vestigingen, 6.500 medewerkers en 10.000 studenten behoort Wageningen University \& Research wereldwijd tot de aansprekende kennisinstellingen binnen haar domein. De integrale benadering van de vraagstukken en de samenwerking tussen verschillende disciplines vormen het hart van de unieke Wageningen aanpak. 